Ana Cristina Vigliar Bondioli

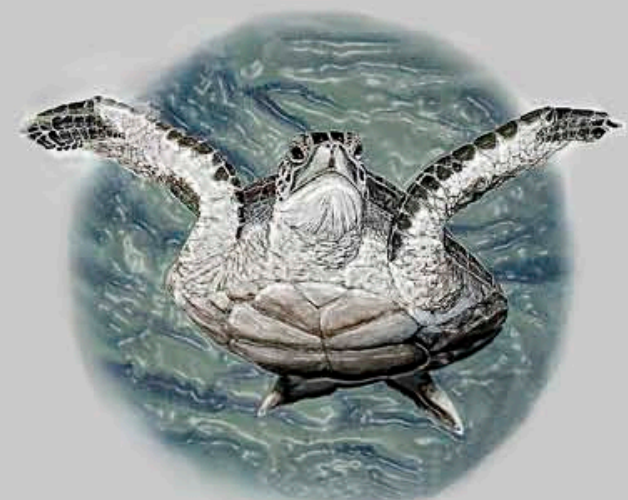

Estrutura populacional e variabilidade genética de tartaruga verde (Chelonia mydas) da região de Cananéia, São Paulo.

São Paulo 


\section{Estrutura populacional e variabilidade genética de tartaruga verde (Chelonia mydas) da região de Cananéia, São Paulo.}

Tese apresentada ao Instituto de Biociências da Universidade de São Paulo, para a obtenção de Título de Doutor em Ciências, na Área de Biologia/Genética.

Orientadora: Profa. Dra. Lurdes Foresti de Almeida Toledo

São Paulo 2009 


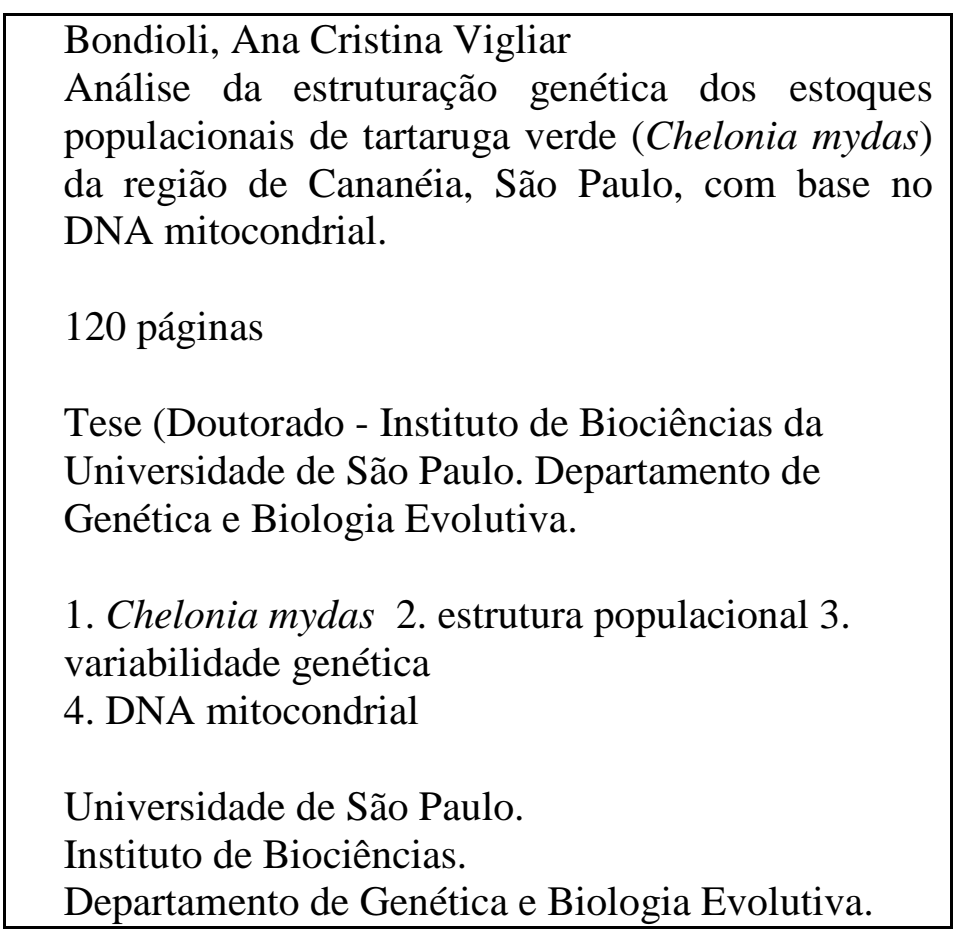

\section{Comissão Julgadora}

Prof(a). Dr(a).

Prof(a). Dr(a).

Prof(a). Dr(a).

Prof(a). Dr(a).

Profa. Dra

Orientadora 


\section{Dedicatória}

Aos meus pais, Pelo amor incondicional

E às tartarugas marinhas, Por povoar meus sonhos. 


\section{Epígrafe}

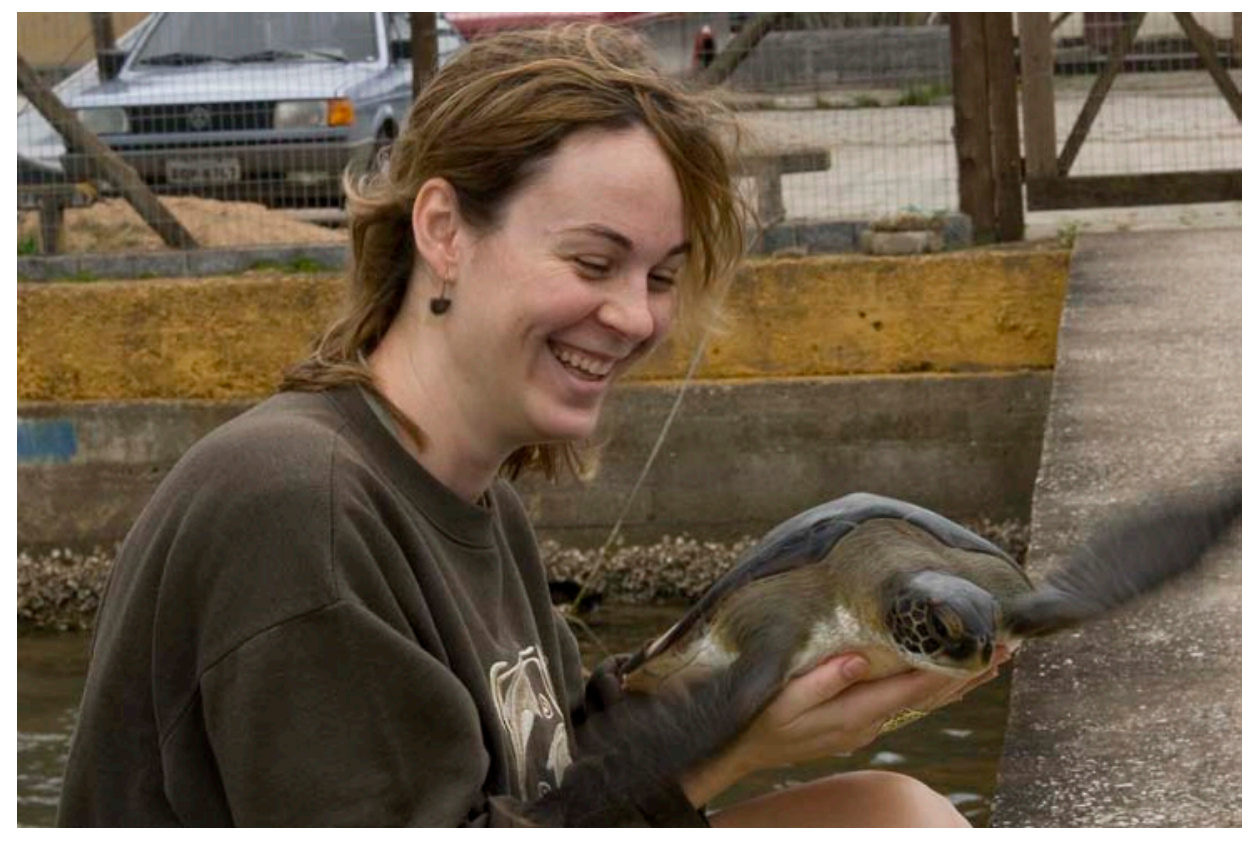




\section{Agradecimentos}

Esta foi uma longa e divertida, por vezes, dificil jornada que se encerra aqui! Tenho realmente muito o que agradecer e consigo resumir tudo em uma única palavra: amizade. Sem o apoio e o carinho incondicional de parentes e amigos verdadeiros este trabalho não teria chegado ao final. Foram momentos tensos, angustiantes, mas sem dúvida nenhuma, o que mais houve foram caminhadas, risadas, alegria e muito carinho!!

Agradeço a Deus em primeiro lugar, por iluminar meus passos nesta etapa da minha caminhada. Minha mãe, guerreira e única, pelo apoio e amor incondicionais. Pai, sua presença faz uma falta absurda, principalmente em momentos como este, mas sei que está por perto, sempre voltando meus passos na direção correta, obrigada sempre! $\mathrm{Bi}$, preciso agradecer pelos presentes que deram muito mais cor a minha vida: minha querida cunhada Rânia, e os afilhados mais lindos que alguém pode ter: Morgana e Renato.

A minha querida madrinha Sâmia, pelo eterno exemplo de mulher de fibra, sempre com um lindo sorriso no rosto e um abraço macio. A Carô e Mari, minhas primas lindas e tão queridas, sempre compreendendo minhas ausências prolongadas por conta do trabalho. Ao tio mais incrível que alguém pode ter, uma mistura de pai e irmão mais velho, um verdadeiro anjo da guarda, Marcelo Vigliar. Obrigada por toda a ajuda e todo amor, confesso que não mereço tanto. E obrigada por me dar a "Titia" Ana Cláudia, e meus lindos e queridos irmãos mais novos, Henrique e Lucas, as coisas mais gostosas desse mundo! A minha prima Gertrudes, um grande orgulho, eterna amiga, obrigada por aguentar minhas angústias e maluquices de sempre!

Aos meus queridos avós Risoleta e Ermelindo, com quem tive o prazer de conviver grande parte da minha vida, pessoas com quem nós pudemos contar em definitivamente todas as situações. Esse trabalho também é de vocês!

Ao meu único e verdadeiro amor, Jefferson Collacico, por voltar a caminhar ao meu lado e fazer da vida uma aventura tão deliciosa. Seu incentivo foi fundamental e tornou a fase final deste trabalho muito mais tranquila e prazeirosa.

Gostaria de agradecer em especial duas grandes e queridas amigas, Janice Cunha e Julia Klaczko pelos conselhos preciosos, pela paciência e carinho de todas as horas. Aos amigos do Museu de Zoologia, que foram fundamentais nessa caminhada: Ilana, Carine (minhax cariocax), Raquel, Flavio, Pedro, Maurício e a todos os queridos colegas e funcionários, especialmente Cida, Mercis, Marta, Chico e Vanderley. Ao Felipe Franco Curcio, um amigo muito especial, por aguentar minhas choradeiras e ter sempre uma idéia 'dimaisss'! Obrigada por ser tão querido e por todas as piadas e incentivos em momentos tão difíceis. Ao amigo Luis Fábio, pelas rápidas conversa e preciosos conselhos, um grande exemplo: "eu quero ser como você, quando eu crescer!" Ao Tuca, por dividir essa vidinha de pós comigo, com direito a muitos perrengues e risadas! Pelas ajudas informáticas e pelo carinho de sua amizade à moda baiana. Ao Marco Sena, meu fiel amigo de USP, Cananéia, répteis e tudo mais! Sua companhia foi essencial desde o início deste trabalho e, sua ajuda e amizade foram e continuam sendo inestimáveis. A princesinha Vânia, por toda ajuda deste mundo. Não consigo imaginar o que seria deste trabalho sem a sua fiel ajuda e amizade. A Mari, Felipe e Carlos, colegas queridos do Laboratório de Ictiogenética, sempre prestativos e muito queridos.

A Deise, Helenice, Erika e Helder por toda paciência e ajuda nos assuntos acadêmicos. 
Aos meus queridos e inesquecíveis amigos de UFSCar: Georgia, Fernanda, Alvimar e Marc, vocês vivem em meu coração para sempre.

Ao eterno companheiro James, pelas longas conversas, discussões e desabafos, sem palavras para descrever o valor de tudo isso.

Aos queridos estagiários Javier, Grazi, Gabriela, Luis e Henrique, obrigada pela ajuda em campo e pelo grande incentivo, resultante da imensa expectativa de aprender.

A familia IPeC por todo suporte e amizade que se pode contar, em especial aos amigos Fernando, Helô, Lisa, Ana Rita, Shan, Kakulé e Fred.

A mini-republica, pelos momentos inesquecíveis e pelas histórias que devo contar aos meus netos: Gica, Manu e Letícia. Vocês são minha família! Isto definitivamente inclui Luciene Mignani, Bruna Coelho e Tatiane Puzzoni! Amo muito vocês!

Ao chefinho, Emygdio e a minha querida mestra, Dra. Lurdes. Obrigada por toda a confiança que depositaram em mim!!! Não consigo descrever em palavras os exemplos que vocês se tornaram em minha vida.

Aos meus queridos e incomparáveis alunos, os melhores que alguém pode sonhar em ter: Bárbara, Natália, Larissa, Aninha, Daiana, João, Cátia, Natasha e Luiz. Esta é a melhor equipe de trabalho que alguém pode desejar! Cada um, a seu modo, me ensinou muito mais do que aprenderam comigo, tenho certeza disto!

Gostaria de agradecer em especial a todos os pescadores, grandes amigos de todas as horas, em especial a Familia Neves! Dico, Sr. Toninho, Sr. Ivo, Ademir, Leandro, Antonio, João, Tiago, Ivan, Ivaldo, Noeli, Vanessa e Vania, muito obrigada sempre. Agradeço também ao Pedrinho, Sr. José Carlos, Sr. Evaristo e Vica. Aos funcionários do Parque Estadual Ilha do Cardoso em especial a Cidinha, Nanke, Marlene, Lair e ao ex-diretor do PEIC, Marcos Campolin, obrigada por toda ajuda e apoio!! Ao Ilso, meus braços direito e esquerdo, companheiro fiel de trabalho com quem sempre pude contar, muito obrigada! Aos motoristas dos ônibus de Ilha Comprida em especial ao Isaias, pelas caronas e avisos sobre as tartarugas. A família Lagamar, em especial ao Adriano, Roberta, Suelen e Chiquinho!

Agradeço especialmente a minha grande amiga Noel, por toda paciência e ajuda deste mundo, por me ensinar que amizade verdadeira não tem fronteiras.

Ao maior tartarugueiro que já conheci, Alejandro Falabrino, por todos os ensinamentos sobre tartarugas e conservação, pelos conselhos, broncas e ajudas inestimáveis e pelas milhares de risadas, dale Pato!

Ao Alejandro Marquez, meu querido amigo por toda, toda ajuda! Não há palavras suficientes para te agradecer!

A Dra. Eugenia Naro-Maciel, por abrir as portas do American Museum, por toda a ajuda nas análises, pelas discussões bastante produtivas e pela recepção calorosa em Nova York. Muito obrigada!

Ao Instituto de Pesquisas Cananéia, que transformou o sonho de trabalhar com tartarugas em realidade, isto jamais seria possível sem o total e irrestrito apoio, tanto do Instituto, quanto de sua equipe.

Ao Museu de Zoologia, em especial ao Prof. Dr. Mario de Pinna, por permitir o desenvolimento desta tese no Laboratório de Biologia Molecular desta Instituição.

E, por fim, a Fundação de Amparo a Pesquisa do Estado de São Paulo por fornecer apoio financeiro a realiação deste trabalho. 


\section{Índice}

Resumo 10

Abstract 11

Introdução Geral 12

Capítulo 1

1.1 Biologia e Ecologia de Tartarugas Marinhas 15

1.2 Conservação 24

1.3 Genética aplicada a conservação de tartarugas marinhas 28

1.4 Estudos populacionais 31

Capítulo 2

2.1 Cananéia: Estruturação e Análise Populacional 36

2.1.1 Introdução 36

2.1.2 DNA Mitocondrial 37

2.1.3 Áreas de Alimentação 38

2.2 Objetivos 42

2.3 Metodologia $\quad 42$

2.3.1. Área de Estudo $\quad 42$

2.3.2 Coleta de Tecidos 45

2.3.3 Processamento das Amostras 46

2.3.4 Análise de dados 48

2.4 Resultados 49

2.5 Discussão

2.5.1 Dados Populacionais 55

2.5.2 Diversidade Genética em Cananéia 55

2.5.3 Análise Temporal 59

2.5.4 Diferenciação Genética: Áreas de Alimentação do Atlântico 61

\section{Capítulo 3}

3.1 Análise dos Estoques Populacionais: Áreas de Alimentação

e Desova do Atlântico Sul Ocidental 63

3.1.1 Introdução 63

3.1.2 A contribuição dos dados moleculares 63

3.1.3 A conectividade entre as áreas de alimentação 65

$\begin{array}{ll}3.2 \text { Objetivos } & 66\end{array}$ 
3.3 Metodologia 66

3.3.1 Testanto a hipótese de "Estoque Misto" 67

3.3.2 Análise de Estoque Misto: Máxima Verossimilhança 67

3.3.3 Análise Bayesiana: Many-to-One 68

3.3.4 Análise Bayesiana: Many-to-Many 69

$\begin{array}{ll}3.4 \text { Resultados } & 70\end{array}$

3.4.1 Testando a hipótese de "Estoque Misto" $\quad 70$

3.4.2 Análise de Estoque Misto: Máxima Verossimilhança e Bayes 72

3.4.3 Análise Bayesiana: Many-to-One $\quad 72$

3.4.4 Análise Bayesiana: Many-to-Many $\quad 75$

$\begin{array}{ll}3.5 \text { Discussão } & 79\end{array}$

3.5.1 Análise de Estoque Misto: Máxima Verossimilhança 79

3.5.2 Análise Bayesiana: Many-to-One $\quad 80$

3.5.3 Análise Bayesiana: Many-to-Many 81

\section{Capítulo 4}

4.1 A utilização de dados moleculares na elaboração de planos de manejo e conservação $\quad 86$

4.1.1 Introdução $\quad 86$

4.1.2 A manutenção da diversidade genética $\quad 87$

4.2 Objetivos $\quad 89$

4.3 Metodologia $\quad 90$

4.4 Resultados $\quad 91$

4.5 Discussão 92

Conclusão Geral $\quad 94$

Anexo I $\quad 95$

Referências Bibliográficas $\quad 96$ 


\section{Resumo}

As tartarugas marinhas são répteis existentes ao longo da costa brasileira, principalmente em áreas de alimentação e anidação. Por possuírem comportamento migratório, estudos ecológicos sobre esses animais são muito difíceis de realizar e muitas questões sobre sua biologia permanecem obscuras. A biologia molecular é uma importante ferramenta, que auxilia os pesquisadores na obtenção de informações valiosas a respeito de estrutura populacional, filogeografia e genealogia de populações naturais. Assim, este trabalho teve como objetivo analisar populações de tartarugas verdes (Chelonia mydas) que freqüentam a região de Cananéia, SP, com base na variedade haplotípica das seqüências gênicas correspondentes ao tRNA-Pro+D-loop do DNA mitocondrial. A área de estudo foi descrita como uma área de alimentação para juvenis de tartarugas verdes, Chelonia mydas, sendo caracterizada pela presença de um estoque misto, composto por animais provenientes de pelo menos seis diferentes áreas de desova analisadas durante quatro anos. A variabilidade haplotípica e nucleotídica é intermediária em relação às demais áreas de alimentação estudadas no Oceano Atlântico, sendo a amostra composta principalmente por indivíduos dos haplótipos CM08 (63\%) e CM-05 (26\%). Os demais haplótipos foram relativamente raros, apresentando-se em frequências menores que 5\% (CM-01, CM-06, CM-09, CM-10, CM-24, CM-32, CM-36, CM-45). Foi detectada diferença significativa entre as amostras anuais $(p<0.05)$ e não houve diferença entre as amostras sazonais $(p>0.05)$.

Análises indicam que Cananéia encontra-se conectada com as demais áreas de desova e alimentação estudadas no Oceano Atlântico, dependendo destas para o equilíbrio de populações saudáveis e necessitando de atenção, visto o grau atual de ameaça que sofrem. A importância da incorporação de parâmetros ecológicos que contribuam para o entendimento da dinâmica populacional da região, às análises genéticas, é imprescindível para que esses dados sejam validados e tenham utilidade e aplicação direta na proteção das tartarugas marinhas.

As informações obtidas através deste trabalho foram utilizadas na elaboração de um documento que será anexado ao plano de manejo do Parque Estadual Ilha do Cardoso e contribuirão para a elaboração do plano de manejo da Área de Proteção Ambiental de Ilha Comprida, de modo que a região de Cananéia seja considerada prioitária na preservação das tartarugas verdes. 


\begin{abstract}
The green turtle, Chelonia mydas, is an endangered marine reptile that nests and forages along the Brazilian coast and oceanic islands, among other tropical areas. Due to the highly migratory and oceanic nature of these animals, ecological studies are many times difficult to carry out, and many questions about their biology remain. Molecular genetic analysis is a powerful tool for bridging these gaps, providing valuable information about population structure, phylogeography, and genealogy. This study analyzes mitochondrial DNA sequences (tRNA-Pro + D-loop) from green sea turtles of the Cananéia regional juvenile feeding ground over a four-year period. Significant differences were found between annual samples $(p<0.05)$, however no significant differences were found between seasons ( $p>0.05$ ). The sample was composed primarily of individuals of haplotypes CM-08 (63\%) and CM-05 (26\%). All other haplotypes ( $\mathrm{n}=$ 8) were relative rare, with frequencies lower than $5 \%$. The analysis revealed the area to be a "mixed stock", composed of animals drawn from at least six different nesting areas. Because Cananéia is connected to other nesting and feeding grounds throughout the Atlantic Ocean, the health of these populations is interdependent, and threats in one area will likely impact connected sites. This connectivity underscores the importance of understanding regional population dynamics using genetic analysis, with conservation applications. These data will be included in the management plans for the Ilha do Cardoso State Park and the Environmental Protection Area of Ilha Comprida, so that Cananéia will be considered a priority area for the preservation of green sea turtles in Brazil.
\end{abstract}




\section{Introdução Geral}

Biodiversidade é o termo que descreve o conjunto de todos os seres vivos, os ecossistemas em que vivem e os processos biológicos dos quais fazem parte. A humanidade depende de tal diversidade, utilizada como recursos alimentares e farmacêuticos, que apresenta um grande potencial para fornecer outros benefícios ainda desconhecidos (Wilson, 1997). Estima-se que 1,8 milhões de espécies vivas foram descritas e a maioria dos pesquisadores concorda que estes números ainda estão muito distantes da diversidade total que habita este planeta (IUCN, 2008). As projeções para o número absoluto de espécies variam entre 5 e 30 milhões de organismos (IUCN, 2008), muitos dos quais não serão sequer conhecidos pela humanidade, dado o ritmo de destruição acelerado.

Existe um valor estético agregado à biodiversidade que pode ser exemplificado pelo apreço a plantas ornamentais, animais domésticos, zoológicos, ecoturismo e documentários sobre a vida selvagem. Essa indústria que gera milhões de dólares todos os anos é movida pela necessidade e o conforto trazido ao ser humano através do contato com o ambiente natural. Há também, uma justificativa ética para a conservação dessa diversidade, baseada no fato de que uma espécie não tem direito de condenar outras à extinção (Frankham, 2004).

Apesar da importância descrita acima, a natureza vem sendo destruída rapidamente, como consequência direta e indireta das atividades humanas. Espécies ameaçadas sofrem declínio principalmente devido à perda de habitat, exploração, introdução de espécies exóticas e poluição. Em populações pequenas, fatores adicionais como a demografia, risco ambiental, o perfil genético e catástrofes aumentam o risco de extinção (DeSalle, 2004).

A biologia da conservação busca descrever padrões e processos que colocam inúmeras espécies em ameaça iminente de extinção. Este ramo da ciência é conhecido como “disciplina da crise”, pois descreve adequadamente a situação atual da biodiversidade da Terra, que passou por dois séculos de intensa atividade exploratória e, como consequência vive um dos mais severos períodos de extinção de todos os tempos (DeSalle, 2004). A escala deste problema alcança tal magnitude que é descrita como a "Sexta Extinção" sendo, portanto, comparada às outras cinco extinções em massa reveladas pelo registro geológico (Frankham, 2004). 
A extinção, no entanto, é parte natural do processo evolutivo e é balanceada pela especiação, processo pelo qual se originam novas espécies, mantendo deste modo um equilíbrio natural. Extinções em massa foram provocadas por cataclismas que eliminaram a fauna e flora quase que em sua totalidade; espécies que levaram milhões de anos para proliferar (DeSalle, 2004). A sexta extinção é igualmente dramática; as taxas de perda de espécies registradas atualmente são muito superiores a origem de outras (Pimm, 2000).

Avanços técnológicos como o aumento da integração de sistemas de posicionamento geográficos (GPS), o desenvolvimento de teorias matemáticas e o florescimento da genética contribuem para o diagnóstico e desenvolvimento de possíveis soluções que buscam aplacar a atual crise ambiental. Em particular, o avanço da genômica, da sistemática e da biologia populacional tem contribuído para a integração da genética e da biologia da conservação (DeSalle, 2004).

A genética da conservação surgiu como parte integrante da biologia da conservação e é motivada pela necessidade de reduzir as taxas atuais de extinção e preservar a biodiversidade. É o uso da teoria genética e suas técnicas com objetivo de reduzir o risco de extinção sofrido por espécies ameaçadas. Seu objetivo é preservar espécies como entidades dinâmicas, capazes de se adaptar a mudanças ambientais (Frankhan, 2004).

O campo deste ramo da ciência é multidisciplinar e inclui o uso de ferramentas moleculares para elucidar diferentes aspectos da biologia das espécies, relevantes para sua conservação (Frankhan, 1995). A perda da variabilidade genética, a resolução de incertezas taxonômicas, o manejo de populações em cativeiro e as análises moleculares utilizadas em investigações forenses são exemplos de sua importância crucial para o entendimento e manutenção da diversidade para as futuras gerações.

Particularmente, a integração entre estudos genéticos e ecológicos é necessária para o estabelecimento de unidades de conservação, de forma que a maior parte dos indivíduos de uma determinada espécie seja preservada (Moritz, 2002). São necessários conhecimentos integrados sobre o comportamento, dieta, reprodução e dinâmica populacional para se obter uma completa visão de determinada espécie para, por fim, acessar as ameaças que esta enfrenta, podendo desta forma, propor medidas que contribuam de maneira efetiva à sua manutenção (Formia, 2002). 
Animais de grande longevidade, as tartarugas marinhas possuem um complexo ciclo de vida, composto por etapas que ocupam diversos nichos e que inclui grandes migrações, o que dificulta o desenvolvimento de estudos sobre determinadas fases de sua vida (Lahanas, 1998). Diversas questões sobre distribuição e estrutura populacional permanecem pouco compreendidas, sendo a maior parte proveniente de experimentos de marcação e recaptura (Papi, 2000).

O uso de hábitat, a filopatria, o comportamento de acasalamento e os padrões migratórios desempenham papéis importantes na determinação da estrutura populacional, e as técnicas moleculares têm se mostrado importantes ferramentas na ampliação do conhecimento destes comportamentos das tartarugas marinhas, que dificilmente poderiam ser diretamente observados. Além disso, a habilidade de distinguir colônias de desova e analisar estoques mistos presentes em áreas de alimentação contribui para o entendimento da dinâmica de suas populações e, portanto, para o desenvolvimento de ações mitigadoras que visem à preservação destes animais.

O presente projeto pretende contribuir para o entendimento da dinâmica populacional de tartarugas verdes (Chelonia mydas) que frequentam o litoral sul do estado de São Paulo, visando à ampliação do conhecimento de sua biologia, assim como de seu status atual, contribuindo para sua preservação. 


\section{Capítulo 1}

\subsection{Biologia e Ecologia de Tartarugas Marinhas}

As tartarugas são répteis pertencentes à ordem Chelonia. Estes animais caracterizam-se por apresentar uma estrutura corporal bastante conspícua, conhecida como carapaça, formada pela fusão dos ossos das vértebras e as costelas, originando uma armadura rígida que protege o corpo do animal contra choques mecânicos e desidratação. Este caráter é extremamente conservado, sendo apresentado por todos os animais pertencentes a esta ordem e sofreu pouquíssimas modificações durante 200 milhões de anos (Ernest e Barbour, 1989). A carapaça apresenta-se dividida em duas partes, ligadas por pontes ósseas dispostas lateralmente ao corpo do animal: a porção dorsal, conhecida propriamente como carapaça e a porção ventral, o plastrão. Os ossos da carapaça são recobertos por escudos córneos, porém, algumas famílias perderam tal revestimento apresentando o corpo coberto por pele (Ernest e Barbour, 1989).

Outra característica excepcional do grupo é o posicionamento das cinturas pélvica e escapular, dispostas internamente às costelas, uma modificação exclusiva do grupo, que confere uma arquitetura corporal única entre os vertebrados (Garcia-Porta, 2001). Seus membros, assim como o formato da carapaça, são adaptados para o hábito que exibem. Por exemplo, os jabutis apresentam patas robustas que auxiliam a locomoção terrestre e suportam seu peso elevado; ao passo que os cágados e tracajás são dotados de garras, que auxiliam seu deslocamento em terra e membranas interdigitais, que contribuem para que sua locomoção aquática seja eficiente (Pritchard, 1997). O crânio dos quelônios, formado por uma estrutura sólida, desprovida de fenestras temporais (anapsida) é altamente modificado embora bastante primitivo (Zardoya, 2001). As mandíbulas não apresentam dentes e são modificadas em bicos de corte afiado, adaptado a diferentes hábitos alimentares exibidos por estes animais (Wyneken, 2001).

As espécies atuais de tartarugas encontram-se divididas em duas subordens: Pleurodira e Criptodira, diferenciadas principalmente pelo mecanismo de retração do pescoço. Ao primeiro grupo pertencem os animais que retraem a cabeça de forma horizontal e ao segundo, aqueles que retraem o pescoço em forma de "S" para dentro da cintura escapular (Ernest e Barbour, 1989). 
As tartarugas foram descritas originalmente como terrestres. Evidências desta hipótese são provenientes dos primeiros fósseis, pertencentes ao gênero Proganochelys (Gaffney, 1990), de depósitos do Triássico (210 milhões de anos), que possuem uma carapaça bastante ossificada e membros adaptados à vida em terra (Gaffney, 1990). Entretanto, recentemente, um fóssil descoberto na China, apresenta-se controverso diante de tal hipótese. Trata-se de Odontochelys semistestacea (Li, 2008). Segundo este mesmo autor, este animal, apresentava uma carapaça incompleta, formada apenas por sua porção ventral, o plastrão, e sua mandíbula era dotada de dentes. Tais características o distinguem de todos os outros membros da ordem e podem contribuir para o posicionamento, atualmente discutido, dos quelônios em relação às demais ordens dentro da classe Reptilia. Além disto, a origem terrestre do grupo volta a ser discutida, visto que Odontochelys exibe características que apontam para o hábito aquático deste animal de 220 milhões de anos.

As tartarugas marinhas apresentam uma longa história evolutiva, durante a qual compartilharam os oceanos com uma rica diversidade de outros répteis pulmonados (Lutcavage, 1997). O registro fóssil anterior ao final do período Cretáceo é representado apenas por Santanachelys (Hirayama, 1998) e Bouliachelys (Kear, 2006) como os mais antigos espécimes deste grupo. Santanachelys possui membros transformados em nadadeiras, apesar de ainda apresentar dígitos móveis, do mesmo modo que as tartarugas de água doce atuais. Além disso, possui um foramen interorbital bastante grande, indicando a presença de glândulas de sal aumentadas na região dos olhos e, portanto, o desenvolvimento do sistema excretor desta substância, anterior à formação dos membros totalmente rígidos que as tartarugas marinhas apresentam atualmente (Hirayama, 1998).

A modificação dos membros para a natação alcançou seu apogeu nas tartarugas marinhas atuais (Pritchard, 1997), que são igualmente caracterizadas pelo formato hidrodinâmico de sua carapaça (Wyneken, 2001) e a presença de glândulas lacrimais altamente modificadas cuja função é a excreção do excesso de sal ingerido durante sua alimentação (Lutz, 1997).

Estes animais encontram-se agrupados em duas famílias: Dermocheliydae e Cheloniidae. Dermocheliydae caracteriza-se pela extrema redução dos ossos da carapaça que são formados por um mosaico de ossículos poligonais imersos em tecido cartilaginoso, cuja textura assemelha-se à couro (Harless e Morlock, 1979). Apresenta sete quilhas longitudinais bastante conspícuas e seu corpo encontra-se revestido por pele 
e placas córneas estão ausentes. O crânio destes animais não apresenta palato secundário e a maxila superior é dotada de duas cúspides formando uma projeção em "W". Seu pescoço é curto e incompletamente retrátil e suas nadadeiras não apresentam unhas. Encontra-se representada atualmente por uma única espécie Dermochelys coriacea (Linnaeus, 1766), conhecida como tartaruga de couro, a maior espécie entre os quelônios atuais (Pritchard, 1997).

Cheloniidae apresenta a carapaça e plastrão ósseos recobertos por um número variável de escudos córneos. A cabeça e os membros apresentam placas córneas, em número igualmente variável. São animais dotados de palato secundário; a pré maxila não é fusionada ao vomer; há contato entre os ossos parietal e esquamosal; e não há contato entre os ossos da maxila e o quadradojugal. Esta família possui 6 espécies distribuídas em 5 gêneros: Caretta caretta (tartaruga cabeçuda), Lepidochelys kempii (tartaruga kempi), Lepidochelys olivacea (tartaruga oliva) e Eretmochelys imbricata (tartaruga de pente), Natator depressus (flatback), e Chelonia mydas (tartaruga verde) (Pritchard, 1997).

Uma oitava espécie, pertencente ao gênero Chelonia permanece controversa, sendo objeto de debate entre os pesquisadores (Parham e Zug, 1996). Chelonia agassizii foi descrita sob o status de espécie por apresentar um tamanho menor, coloração e formato do corpo distintos de C. mydas. Sua distribuição estaria restrita ao Pacífico Oriental sendo popularmente conhecida como “tortuga negra” (Meylan e Meylan, 1999). Características morfológicas, genéticas e bioquímicas deste animal fornecem resultados discordantes quanto ao posicionamento filogenético do mesmo. Revisões recentes dos dados disponíveis indicam uma profunda separação entre as populações encontradas nas bases Atlântica e Pacífica, contudo não apóiam a distinção entre estas e o morfótipo do Pacifico leste (Bowen, 1992, 1993; Bowen e Karl 1997, Naro-Maciel 2008).

O relacionamento filogenético entre as familias de tartarugas marinhas, tanto a partir de dados morfológicos (Gaffney e Meylan 1988; Hirayama 1994), quanto moleculares (Bowen 1993; Dutton 1996, Naro-Maciel, 2008) indicam se tratar de um grupo monofilético. Dermochelys aparece como grupo basal e irmão da família Cheloniidae. Esta apresenta-se dividida em duas tribos: Carettini, formada por $C$. caretta, E. imbricata, L. olivacea e L. kempii sendo o relacionamento entre as duas últimas espécies bem sustentado (Pritchard 1999; Bowen 1993; Bowen 2007) e Chelonini, que apresenta a espécie $N$. depressus como grupo irmão do gênero Chelonia (Naro-Maciel, 2008). 
Chelonia mydas foi descrita por Linnaeus em 1758, como Testudo mydas e, posteriormente recebeu seu nome atual de Schweigger, em 1812 (Formia, 2002). Este réptil marinho apresenta uma carapaça óssea revestida de escudos córneos justapostos. Os membros são transformados em nadadeiras, sendo as anteriores, dotadas de uma unha bastante evidente. A cabeça apresenta um formato arredondado e sua mandíbula encontra-se revestida por uma estrutura córnea e serrilhada denominada ramfoteca (Wyneken, 2001). Os machos, quando atingem a maturidade, apresentam uma longa cauda, que abriga o órgão copulador, que se estende além da extremidade posterior da carapaça e as unhas da nadadeira anterior são bastante evidentes. Tais características são as únicas que distinguem os sexos, e isto se dá apenas na fase adulta. A coloração é variada em tons de verde, oliva e marron apresentando manchas ou padrões rajados e estriados que podem se alterar bastante durante o desenvolvimento do animal (Formia, 2002). Conhecida popularmente como tartaruga verde, este nome se deve não à coloração exibida por seu corpo e carapaça externamente, mas sim pela tonalidade esverdeada apresentada por sua gordura. O plastrão é branco ou amarelo claro e a pele usualmente é cinza ou marron, apresentando um halo mais claro margeando as escamas e um tom amarelo bastante claro na porção ventral das nadadeiras (Wyneken, 2001).

Quando nascem, os filhotes são cinza escuro ou negros dorsalmente e brancos ventralmente, um padrão de camuflagem conhecido como “countershading” bastante eficiente e recorrente em animais marinhos (Ruxton, 2004). Pesam cerca de 20 gramas e medem aproximadamente $5 \mathrm{~cm}$ de comprimento. Quando adultas chegam a alcançar $230 \mathrm{~kg}$ de peso e até 1,50 m de comprimento curvilíneo da carapaça, sendo portanto, a maior espécie entre as tartarugas de carapaça óssea (Pritchard e Mortimer, 2000; Fig. 01).

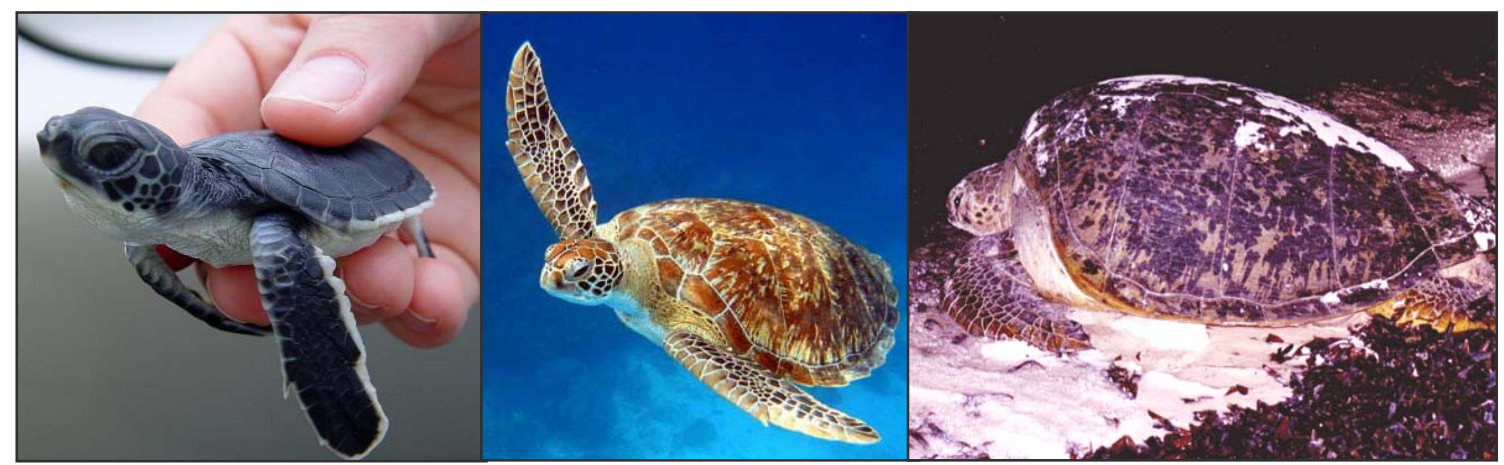

Figura 01. Tartaruga verde em diferentes etapas de seu ciclo de vida. A. Filhote, B. Juvenil e C. Adulto (Fonte: www.seaturtle.org) 
As características utilizadas na identificação desta espécie são: presença de quatro pares de escudos laterais na carapaça, sendo que o primeiro par nunca encontra a placa nucal, dois pares de escamas pré-frontais e quatro pares de escamas pós-orbitais na cabeça (Pritchard e Mortimer, 2000; Fig. 02).

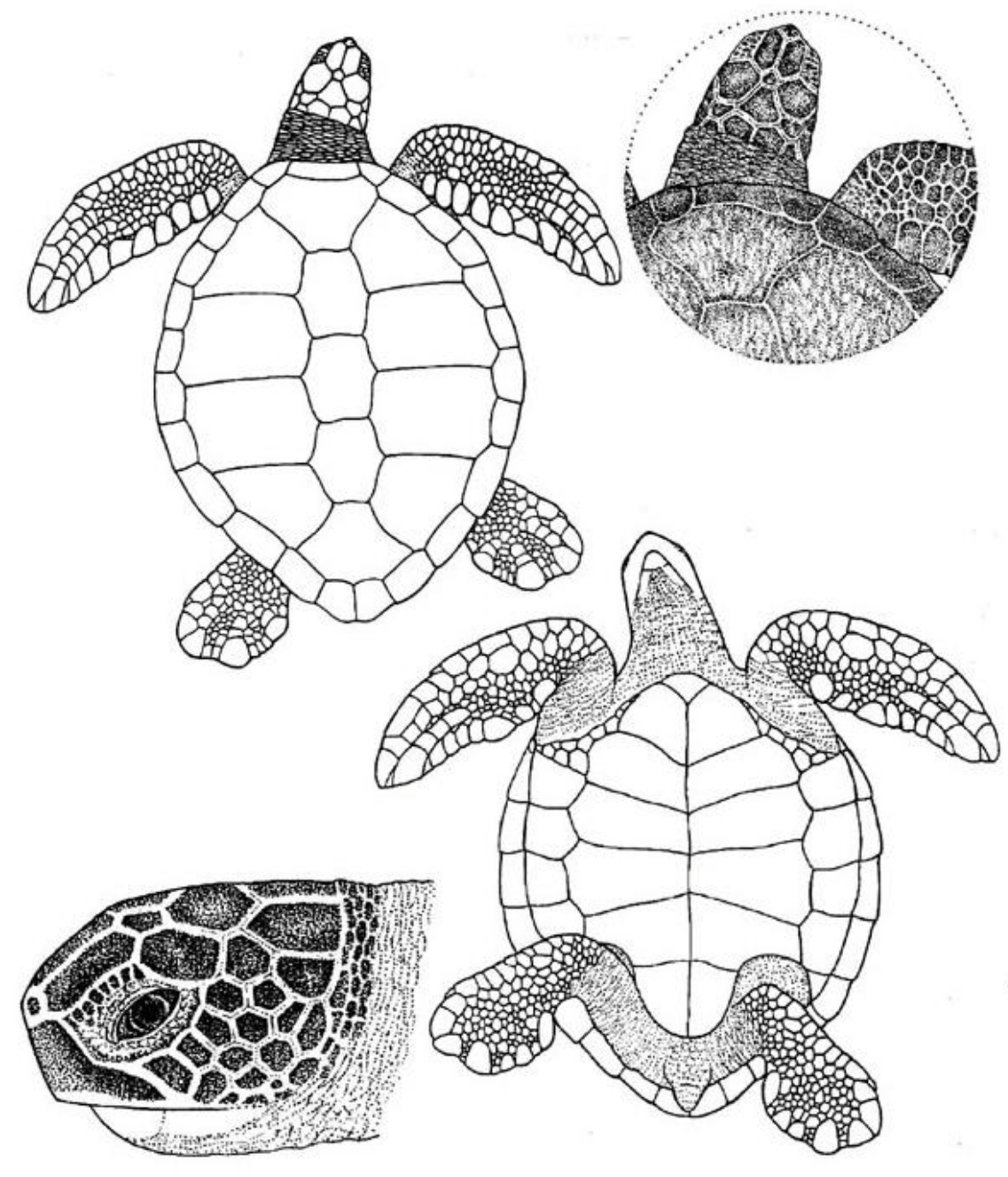

Figura 02. Chelonia mydas. Prancha de Identificação (Pritchard e Mortimer, 2000)

Chelonia mydas apresenta distribuição circuntropical habitando todos os oceanos do globo. A maioria das populações habita regiões entre $50^{\circ} \mathrm{N}$ e $40^{\circ} \mathrm{S}$ de latitude. Estima-se que existam aproximadamente 150 colônias de desova, sendo que apenas 12 destas recebem mais de 2000 fêmeas anidadoras por ano (Formia, 2002). As principais áreas de desova são Austrália, Costa Rica, Canal de Moçambique, Oman, Ilhas Ascensão, costa pacífica do México e provavelmente o Paquistão e a Indonésia (Pritchard, 1997). Entretanto, dados provenientes de monitoramento em longo prazo ainda são escassos e a variação anual no número de fêmeas que visitam cada colônia 
dificulta a obtenção de parâmetros precisos a respeito do status das populações anidadoras.

As tartarugas verdes, assim como as demais espécies de tartarugas marinhas, exibem um complexo ciclo de vida (Fig.03), realizando extensas migrações entre diferentes habitats (Lutz e Musick, 1997; Plotkin, 2003), que distam entre si, centenas ou milhares de quilômetros. Isto dificulta a realização de estudos sobre vários aspectos da vida destes animais e torna seu ciclo de vida ainda hoje pouco compreendido. Além disto, estes répteis apresentam grande longevidade o que torna inviável o acompanhamento das diferentes fases de sua vida.

Historicamente estudos de marcação e recaptura têm sido a atividade mais valiosa e informativa no avanço de nosso entendimento sobre estes répteis e de suas necessidades em relação ao complexo ciclo de vida, às grandes migrações reprodutivas, às taxas de crescimento lentas e à tardia maturação sexual (Balasz, 2000).

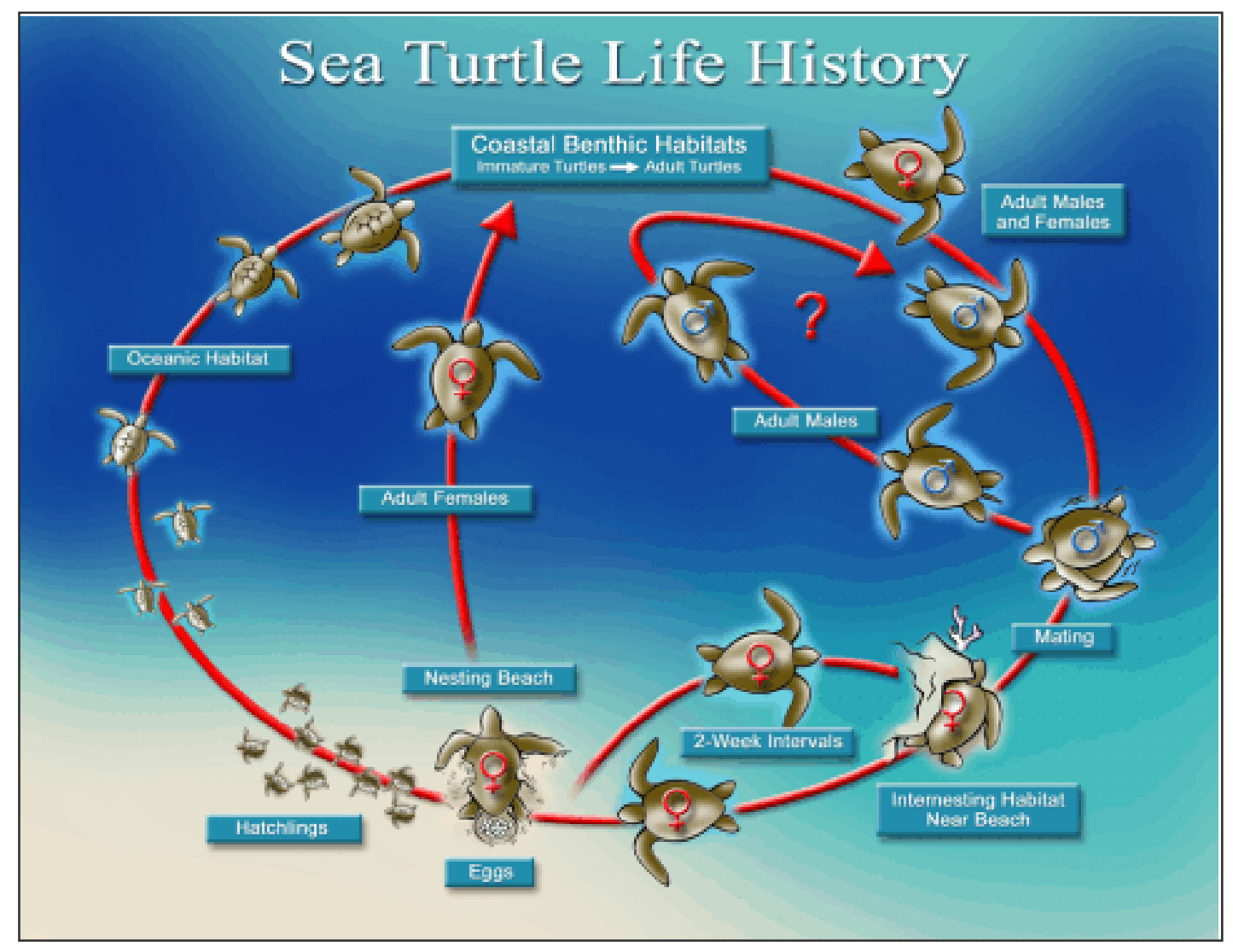

Figura 03. Ciclo de vida das tartarugas marinhas. Fonte: Bárbara Shoeder, (NOAA, 2009). 
A maioria dos aspectos reprodutivos é muito similar entre as sete espécies e as descrições encontradas na literatura, com algumas modificações, se adequam a todas elas.

Os filhotes de tartaruga verde eclodem de seus ovos simultaneamente, apresentando um comportamento em que a atividade de escavação do ninho ocorre em cadeia. A emergência do ninho se dá geralmente no final da tarde ou à noite e é controlada pelo gradiente de temperatura da areia experimentado pelo filhote, ao cavar em direção à superfície (Miller, 1997). Quando o sol se põe, a temperatura da areia cai rapidamente e os filhotes são estimulados a escavar. Assim, cada filhote estimula a escavação de seu vizinho ao iniciar este movimento, facilitando o alcance da superfície, de modo que a maioria dos filhotes emerge na praia ao mesmo tempo, diminuindo com isto, sua suscetibilidade a diversos predadores como caranguejos, aves e mamíferos (Formia, 2002). Durante o percurso ninho-mar, características químicas e físicas da praia natal são registradas por estes filhotes, fenômeno conhecido como “imprinting” e, acredita-se que tais sinais sejam responsáveis pelo seu retorno, anos mais tarde, como adultos em idade reprodutiva, para acasalar e desovar (Lohmann, 1997). Este senso de direção tão refinado, que permite o retorno de uma tartaruga à mesma praia, cinquenta anos depois de seu nascimento, atribui-se também ao campo magnético da terra, que exerce grande influência sobre outras espécies migradoras (Lohmann, 2001).

Ao encontrar a água, os filhotes nadam freneticamente por até 24 horas a uma velocidade média de 1,57 km por hora, em direção perpendicular às ondas (Lohmann, 1990), alcançando o hábitat oceânico.

Durante a fase de vida oceânica conhecida como "ano perdido” (Carr, 1987), os filhotes permanecem boiando passivamente nos maiores sistemas de correntes (giros oceânicos), que servem como áreas de desenvolvimento em mar aberto e que possuem uma baixa densidade e diversidade de predadores. Sabe-se muito pouco a respeito dos hábitos alimentares, comportamento e desenvolvimento destes animais durante esta etapa do ciclo de vida (Bolten e Balazs, 1995; Bowen, 1995; Bolten, 1998; Lahanas, 1998). Isótopos estáveis, extraídos de amostras dos escudos da carapaça de filhotes, foram utilizados para avaliar a ecologia alimentar deste estágio de vida inacessível e indicam que tartarugas verdes apresentam hábito carnívoro durante esta fase oceânica que tem duração de três a cinco anos (Reich, 2007). Após este período são recrutados para áreas neríticas de desenvolvimento, como juvenis. Nesta fase, são frequentemente encontrados próximos à costa, em baías, recifes e regiões estuarinas, ricas em algas e 
angiospermas marinhas, alimento de sua preferência e que proporcionam proteção contra predadores. Estas regiões recebem juvenis de várias áreas de desova distintas (Lahanas, 1998).

Adultos desta espécie exibem a mesma preferência pelo hábito herbívoro, alimentando-se preferencialmente de algas verdes, vermelhas e marrons e angiospermas marinhas de diversas espécies disponíveis em localidades conhecidas como áreas de alimentação, que podem abrigar uma mistura de animais adultos e subadultos de ambos os sexos (Bjorndal, 1997).

O tamanho corporal não indica a idade desses animais de maneira confiável, porque assim como os outros répteis, seu desenvolvimento é proporcional ao aporte alimentar que recebem, podendo alcançar grande porte em menor espaço de tempo, quando se desenvolvem em áreas onde exista grande abundância de alimento (Miller, 1997). Sua dieta é composta por uma grande variedade de espécies de algas, resultante da combinação entre a disponibilidade e um padrão de seletividade do alimento (Formia, 2002). Ocasionalmente são registrados se alimentando de águas-vivas, esponjas, propágulos de mangue, moluscos, peixes e crustáceos (Bjorndal, 1997, Guebert, 2008).

Ao atingir a maturidade sexual, que para estes animais se dá em torno de 30 a 50 anos (Formia, 2002), iniciam grandes ciclos migratórios entre áreas de alimentação e áreas de desova, cruzando zonas oceânicas (Luschi, 2003). Tais migrações são realizadas por machos e fêmeas e a velocidade com que viajam varia entre 1.4 e 3.6 km/hora (Wyneken, 1997).

O mecanismo pelo qual as tartarugas se guiam durante estas migrações permanece desconhecido. Esta habilidade de navegação é atribuída a uma variedade de mecanismos que incluem odor das correntes, parâmetros geomagnéticos e características químicas e físicas provenientes de ventos e correntes (Lohmann, 1997).

Durante os intervalos entre os periodos reprodutivos, adultos geralmente residem em ambiente nerítico. $\mathrm{O}$ acasalamento ocorre em regiões próximas à praia onde a fêmea desova e a promiscuidade é o comportamento dominante durante os acasalamentos (Fitzsimmons, 1998). A fêmea se mostra receptiva ao macho que se posiciona sobre ela, agarrando-a através das grandes unhas que possui nas nadadeiras anteriores. Inicia-se a cópula, pela introdução do órgão copulador do macho na cloaca da fêmea que nada, suportando além do seu peso, o do macho enquanto ocorrer a cópula que dura algumas horas, embora a transmissão de esperma não aconteça durante todo esse periodo (Miller, 
1997). Existem registros de cópulas em cativeiro cuja duração foi superior a dez horas e casos de fêmeas que morrem afogadas devido à longa duração deste comportamento. Após o período de acasalamento, os machos retornam às áreas de alimentação enquanto as fêmeas se dirigem para as proximidades das praias de desova, onde nasceram, e permanecem por um período de tempo, para a maturação dos ovos (Carr, 1978).

Em intervalos de 10 a 15 dias, esta fêmea sobe à areia da praia para colocar seu ninho. Embora existam inúmeros fatores associados à qualidade de uma praia de desova, não há uma relação direta entre estes fatores e a presença de tartarugas em uma determinada praia de anidação. Mortimer (1995) enumerou algumas das qualidades desejadas: a praia deve ser acessível a partir do mar, deve ser alta o suficiente para prevenir a inundação dos ninhos e, com isso a inviabilidade dos ovos, deve ser formada de um substrato que facilite a difusão de gases e a percolação de água, além de ser úmido e fino o suficiente para evitar o colapso da câmara dos ovos durante a construção do ninho.

Os ninhos são escavados pela fêmea, com as nadadeiras traseiras e são depositados entre 100 e 120 ovos em cada um deles (Miller, 1997). Após a deposição, a fêmea recobre de areia o ninho e retorna à água, onde deverá permanecer, até que os outros ovos amadureçam e ela retorne a areia para a construção de um novo ninho e assim sucessivamente. $\mathrm{O}$ número de ninhos a cada temporada reprodutiva varia entre 3 e 7, dependendo da região e de cada indivíduo (Formia, 2002) e, terminada sua última postura, este animal se encaminha para sua área de alimentação, permanecendo nesta região ou alternando entre outras de mesma natureza, até que se inicie uma nova temporada reprodutiva. Chelonia mydas realizada posturas a cada dois ou três anos, tipicamente nos meses de verão (Miller, 1997).

Os ovos são incubados pelo calor do sol nas areias durante um período que varia entre 45 a 60 dias (Miller, 1997) e a determinação do sexo das crias se dá por esta diferença na temperatura de incubação, não havendo cromossomos sexuais que determinem a proporção sexual nestas espécies (Morreale, 1982). A temperatura limite para a definição do sexo, conhecida como temperatura pivotal, varia de acordo com a espécie. Para tartarugas verdes, ela está em torno de $32^{\circ} \mathrm{C}$, acima dos quais, os filhotes serão fêmeas e abaixo dos quais estes serão machos (Standora, 1985). Esta característica sofre influência direta do aquecimento global que acomete o planeta atualmente, podendo gerar consequências fatais para a manutenção destas espécies, decorrentes do 
desequilíbrio na razão sexual resultante da alteração da temperatura nas áreas de desova (Weishampell, 2004; Hawkes, 2007).

\subsection{Conservação}

As populações de tartarugas marinhas têm sofrido reduções drásticas nas últimas décadas. Todas as sete espécies encontram-se listadas como ameaçadas ou em perigo crítico de extinção (IUCN, 2008). Isto se deve principalmente à ação antropogênica, que inclui sua predação direta para o consumo de carne, ovos e carapaça, que é utilizada na fabricação de diversos artefatos (Campbell, 2003).

A carne de tartaruga verde é considerada uma iguaria em vários países (Campbell, 2003). Sua utilização como item alimentar é um hábito histórico que ainda persiste, apesar da ameaça de extinção sofrida atualmente por esta espécie. Em muitas regiões, é comum encontrar sopa de tartaruga, um prato tradicional, muito apreciado, além do comércio de carne e ovos em mercados e restaurantes. A comercialização de sua gordura também é comum na medicina tradicional (Roberts, 1999), porém, não existem estudos que comprovem a existência de propriedades medicinais neste material. No Brasil, todas as espécies de tartarugas marinhas estão legalmente protegidas contra caça e a coleta de ovos, em toda a costa, desde 1986, segundo a portaria $\mathrm{n}^{\circ} 005$ da Superintendência do Desenvolvimento da Pesca - SUDEPE.

Ameaças indiretas agravam a situação destes animais, como a perda de habitats costeiro e marinho, causada pela poluição e a degradação ambiental (Derraik, 2002). Restos de linhas e redes de pesca, plástico e isopor afetam estes animais em todas as fases de seu ciclo de vida. Quando filhotes, podem ficar enredados em dejetos flutuantes, ao longo das zonas de convergência sendo impedidos de se alimentar e se desenvolver (Bjorndal, 1997). Tartarugas verdes juvenis e adultas são herbívoras e frequentemente se alimentam de sacos plásticos que se assemelham as algas e gramas marinhas (Bugoni, 2001). Este fato pode acarretar consequências graves, como a obliteração do trato digestório, a interrupção da alimentação pela sensação de saciedade e a formação de fecalomas produzidos pela compactação do lixo ingerido (Bjorndal, 1994; Lutcavage, 1997).

A ocupação das regiões costeiras pode também comprometer praias de desova, pois a presença humana, muitas vezes, impede as fêmeas de construir seus ninhos, além 
de introduzir nas praias, espécies exóticas e animais domésticos, predadores de fêmeas, ovos e filhotes (Lutcavage, 1997). O desenvolvimento destas ocupações, geralmente envolve a iluminação da região a beira mar. O brilho da luz pode causar desorientação de fêmeas e filhotes que são atraídos para o lado oposto ao mar e acabam morrendo de exaustão e desidratação (Lorne, 2007). Em algumas regiões, a extração de areia altera drasticamente o perfil da praia e as características de incubação deste sedimento impedindo assim, o desenvolvimento dos filhotes. Por fim, o tráfego de veículos causa a compactação da areia e atropelamentos além da destruição de ninhos (Lutcavage, 1997).

Atualmente, entretanto, a captura incidental em larga escala, pela pesca industrial é responsável pelos maiores índices de mortalidade de tartarugas marinhas de todo o globo (Heppel et al., 2003). Entende-se por captura incidental, a captura de animais que não são alvo de um determinado tipo de pesca. Aves e tartarugas são frequentemente capturadas deste modo, principalmente pelo arrasto e o espinhel pelágico, petrechos utilizados na captura de camarões e de peixes de alto valor comercial, respectivamente (Oravetz, 1999; Sasso, 2006; Sales, 2008).

Anteriormente à implementação de medidas de proteção, a mortalidade anual direta de tartarugas cabeçudas e oliva eram estimadas em 50.000 e 5.000 indivíduos, respectivamente, em águas americanas pela pesca de arrasto (National Research Concil, 1990). Em 1978, a agência do governo americano para pesquisa e regulamentação da pesca desenvolveu um sistema conhecido como TED (do inglês, turtle excluder dispositive) que permite o escape de tartarugas, quando capturadas por essas redes (Lutcavage, 1997). Nos anos subsequentes, leis que obrigam o uso deste equipamento em barcos comerciais de pesca de camarão foram implementadas e estima-se que esta medida diminuiu em 44\% a mortalidade de tartarugas cabeçudas, na Carolina do Norte (Crowder, 1995). No Brasil, desde 1997 o uso do TED é obrigatório ao longo de toda a costa, em barcos de pesca de camarão de tamanho superior a 11 metros, que não empregam redes ou métodos manuais de pesca (Portaria n ${ }^{\circ} 000005$ de 19/02/1997; IBAMA, 2009).

As tartarugas marinhas são igualmente vulneráveis à captura por espinhel pelágico e estudos realizados no Atlântico Norte (Ferreira, 2003), Pacífico (Lewinson, 2004) e Mediterrâneo (Gerosa, 1999) mostram indíces significativos de captura e mortalidade. No Brasil, este petrecho é utilizado desde 1956, quando embarcações japonesas foram arrendadas por companhias brasileiras de pesca, em busca de espadartes (Xiphias gladius) e diversas espécies de atum (Thunnus ssp). Sales (2008) 
aponta a necessidade da ampliação do conhecimento a respeito deste tema para realizar análises mais detalhadas sobre o impacto causado, além de servir como base para a elaboração de planos de ação que visem à diminuição de tais índices. A substituição dos anzóis em “J” por aqueles de formato circular é um exemplo de ação que está em andamento visando minimizar este problema, pois anzóis circulares diminuem a captura de tartarugas cabeçudas mantendo os índices de captura de espécies-alvo apresentados pelos anzóis em “J” (Swimmer, 2006).

A colisão com embarcações, pode causar ferimentos graves e frequentemente levar à morte, principalmente em alta velocidade (Witzell, 2007; Hazell, 2007). Na Flórida, onde embarcações costeiras são bastante comuns, a frequência de injúrias causadas às tartarugas por colisões com embarcações entre 1991 e 1993 foi de 18\% em 2156 encalhes. Embora algumas colisões possam vir a ocorrer após a morte, estes dados indicam que o tráfego de embarcações é uma importante causa de mortalidade para estes animais (Lutcavage, 1997).

Doenças e parasitas são ameaças naturais ainda pouco compreendidas. A fibropapilomatose é uma doença caracterizada pelo crescimento de tumores, internos ou externos, de tamanho bastante variável (Aguirre, 1998) e cuja causa, apesar de incompletamente determinada, suspeita-se ser de origem viral associada a fatores como a poluição e aquecimento das águas (Greenblatt, 2005; Foley, 2005). Estes tumores comprometem comportamentos essenciais à sobrevivência destes animais como a alimentação e deslocamento e, quando acometem os olhos podem causar cegueira levando o animal à morte.

Parasitas externos, como sanguessugas marinhas da espécie Ozobranchus branchiatus são frequentemente encontrados fixados às tartarugas verdes (Willians, 2008; Adnyana, 1997) e podem estar associados ao desenvolvimento de tumores, visto que causam pequenas fissuras na pele, consideradas uma importante via de contaminação viral (Willians, 1996). Outros invertebrados foram descritos como parasitas internos destes répteis sendo encontrados principalmente no trato digestório, pulmões, baço e bexiga urinária (Santoro, 2007). Estudos sobre estas relações parasíticas são ainda escassos, de modo que frequentemente novas espécies são descritas neste tipo de associação (Werneck, 2006) e o completo entendimento destas se faz necessário a fim de se obter um panorama da verdadeira ameaça que representam. 
Conforme descrito acima, inúmeros fatores dificultam a conservação das tartarugas marinhas. Seu comportamento altamente migratório indica a necessidade de esforços cooperativos nacionais e internacionais para sua conservação. Muitas tartarugas que se utilizam de áreas de alimentação brasileiras, por exemplo, nasceram em praias africanas dependendo, deste modo, de esforços conjuntos destes países para que possam ser efetivamente protegidas. Ao atingir a idade reprodutiva, esses animais retornarão a África para construir seus ninhos e, se porventura sofrerem ameaças nestes locais, os esforços brasileiros na preservação desta espécie terão sido de pouca utilidade e vice-versa.

Outro fator importante, diz respeito à distribuição tropical e subtropical destes animais. Muitos de seus habitats encontram-se em países em desenvolvimento onde as condições econômicas são precárias e cujos habitantes, muitas vezes dependem destes recursos naturais como única fonte de proteína e energia (Formia, 2002).

Por fim, seu ciclo de vida exibe mecanismos e comportamentos sensíveis a alterações ambientais que podem facilmente ser modificados ou interrompidos gerando consequências graves à manutenção de suas populações (Formia, 2002). A determinação sexual dos filhotes, pela temperatura de incubação dos ninhos é um exemplo bastante claro. A proporção sexual nas populações pode ser alterada pelo aquecimento global causando desequilibrio entre machos e fêmeas. O comportamento filopátrico é igualmente sensível a distúrbios provocados nas praias de desova. Fêmeas que não retornam à praia onde nasceram para colocar seus ovos podem contribuir para o surgimento de novas colônias (Bowen, 2007), porém, na maioria dos casos, perdidas por alterações ou ausência das informações necessárias à execução deste comportamento, acabam por construir seus ninhos em praias que não possuem condições adequadas à incubação de seus ovos.

Durante muito tempo, os esforços conservacionistas foram direcionados para a identificação de ameaças, particularmente em áreas de desova, onde filhotes e fêmeas adultas encontram-se mais acessíveis. Dada a alta taxa de mortalidade nos primeiros estágios de vida e o longo tempo de geração, pesquisadores de todo o mundo direcionaram sua atenção para a conservação de adultos, em idade reprodutiva. Considerada a fase onde existe maior ameaça humana, o decréscimo na mortalidade de adultos tem grande efeito na viabilidade das populações em longo prazo. Entretanto, tais esforços mostraram-se insuficientes para a manutenção das populações. Apesar de as 
tartarugas marinhas passarem menos de 1\% de seu ciclo vital em praias de anidação, 90\% dos estudos sobre a biologia destas espécies se baseiam em informações coletadas nestas localidades (Bjorndal, 2000). Isto indica claramente, a necessidade de se realizarem estudos sobre outras etapas do ciclo de vida, com o intuito de obter um completo entendimento da biologia destes répteis.

Estudos demográficos indicam que a mortalidade de juvenis tem maior impacto nas populações que a perda de ovos e filhotes. Assim, embora a proteção de áreas de desova seja considerada prioritária, esta terá pouca utilidade, caso os juvenis não sobrevivam para se desenvolver até a maturidade. O conhecimento sobre esta fase, apesar de ainda incipiente, trouxe contribuições importantes para o entendimento da ecologia alimentar (Boyle, 2008; Arthur, 2008) e de aspectos comportamentais (Avens, 2003; Revelles, 2007) além de detectar ameaças (Koch, 2006) anteriormente desconhecidas, criando demanda de ações mitigatórias que visem à preservação desta etapa fundamental para a manutenção da variabilidade dessas espécies.

\subsection{Genética aplicada à conservação de tartarugas marinhas}

Análises genéticas são utilizadas para responder uma ampla gama de questões a respeito de indivíduos, populações e espécies, que ainda permanecem sem resposta devido a determinadas características dos organismos estudados, como por exemplo, ao se tratar de espécies raras, altamente sensíveis a distúrbios ou que ocupam habitats inacessíveis (Formia, 2002). Nas últimas décadas, as ferramentas moleculares têm esclarecido vários aspectos de vida das tartarugas marinhas. Muitas técnicas, como a eletroforese de proteínas, RFLP (Restriction Fragment Length Polymorphisms), RAPDs (Random Amplification of Polymorphic DNA) e microssatélites são úteis na descrição de caracteríticas como estrutura social e demográfica, sistemas de acasalamento, análise de paternidade e relações de parentesco, sucesso reprodutivo, endocruzamento, hibridização, comportamento migratório, viabilidade populacional e suscetibilidade a alterações ambientais (Conceição, 1990; Schroth, 1996; Moore, 2003; Jensen, 2006).

A elucidação sobre o funcionamento de aspectos comportamentais é importante na elaboração de estratégias que visem à preservação destas espécies. Por exemplo, uma das primeiras observações resultantes de estudos de marcação e recaptura desenvolvidos 
nas décadas de 1950 e 1960 foi o retorno das fêmeas à mesma praia, em ciclos reprodutivos de 2 a 4 anos. Este comportamento levou Carr, (1967) a postular que fêmeas migravam para as praias onde nasceram para se reproduzir, fenômeno ao qual deu o nome de "natal homing”. Alternativamente, Hendrickson, em 1958 formulou uma hipótese denominada "facilitação social” segundo a qual, fêmeas mais experientes, guiariam as fêmeas em sua primeira estação reprodutiva até uma determinada praia de desova e, estas, após aprenderem o caminho, continuariam visitando a mesma área durante todos os ciclos reprodutivos subsequentes. Esta teoria poderia explicar a fidelidade das fêmeas a uma determinada área de desova sem invocar um comportamento tão extremo em que filhotes de apenas $5 \mathrm{~cm}$ localizariam com sucesso a praia onde nasceram, décadas depois, para se reproduzir (Bowen, 2007). Entretanto, o advento das ferramentas moleculares tornou possível testar a hipótese proposta por Carr, que foi corroborada, para a maioria das espécies (Meylan, 1990; Broderick, 1994; Hatase, 2002; Shanker, 2004; Dutton, 1999), visto que análises do DNA mitocondrial demonstraram uniformidade genética entre fêmeas de uma mesma área de desova que é transmitida aos seus descendentes. Estudos sobre este tema tornaram-se bastante aprofundados determinando o mesmo comportamento para machos (Fitzsimmons, 1997) e para juvenis (Avens, 2003; Bowen, 2004). Recentemente, pesquisadores têm voltado a atenção ao refinamento de tais análises, visto que, embora esteja claro o retorno à praia natal, a especificidade geográfica deste comportamento permanece desconhecida. Ao analisar colônias situadas em Fernando de Noronha e Atol das Rocas, Bjorndal (2006) encontrou forte estruturação genética entre ilhas que distam 1800 km porém não houve diferença entre ilhas separadas por $150 \mathrm{~km}$. Lee (2007) utilizou microssatelites para acessar a diferenciação genética existente entre três praias localizadas em Ascensão e, demonstrou que as fêmeas exibem este comportamento com maior precisão que os machos porém este não gera diferenças significativas entre as diferentes praias de uma mesma colônia. O esclarecimento genético acerca deste comportamento impulsionou inúmeros trabalhos afim de descrever a estrutura populacional exibida pelas diferentes espécies, assunto que, necessita ainda ser completamente esclarecido (Bowen, 2007).

O comportamento reprodutivo é também um componente central na história de vida de um animal e, o conhecimento detalhado dos sistemas de acasalamento é fundamental na avaliação do status de populações ou espécies ameaçadas (Zbinden, 2007). A análise de paternidade é de grande interesse no estudo dos quelônios marinhos 
visto que se trata de um método indireto de análise da biologia reprodutiva que, de outra forma, seria inacessível, devido ao habitat marinho. Existem poucos registros do comportamento de côrte em populações selvagens de tartarugas marinhas, porém a existência de múltipla paternidade em seus ninhos está bem descrita na literatura (Ireland, 2003; Moore, 2002; Hoeckert, 2002). Isto se dá devido à presença de um ducto armazenador de esperma, posicionado na porção posterior da região secretora de albumina do oviduto (Galbraith, 1993) e ao comportamento promíscuo de acasalamento, ambos exibidos pelas fêmeas de tartarugas marinhas (Fitzsimmons, 1998). As vantagens decorrentes da múltipla paternidade permanecem em debate, porém a maioria dos pesquisadores concorda que esta poderia ocorrer em espécies onde o macho não contribui no cuidado parental e, onde as fêmeas possuem poucas oportunidades de avaliar o fitness dos parceiros antes da cópula (Bowen, 2007). Ambas as condições se aplicam às tartarugas marinhas que, ao exibir tal comportamento, possuem maior garantia de fertilização dos ovos, aumento no fitness através da competição espermática e um aumento da variabilidade genética e, portanto, da sobrevivência de seus descendentes (Pearse, 2001).

A hibridização é outro aspecto da biologia reprodutiva bastante peculiar nas populações de tartarugas marinhas e, com exceção de $D$. Coriacea, é exibida entre todas as espécies de distribuição cosmopolita (Karl, 1995; Seminoff, 2003; Bowen, 2007). O tempo de divergência estimado entre algumas espécies é superior a 50 milhões de anos (Dutton, 1996) e a existência de híbridos entre elas é atribuída às taxas de evolução molecular lentas (Avise, 1992), aliadas ao comportamento de acasalamento indiscrimidado exibido pelos machos. Da mesma forma, a manutenção do número e estrutura cromossômica idênticos entre as espécies indica que a evolução das barreiras reprodutivas ocorreu lentamente entre estes animais e está intimamente relacionada à ocorrência de híbridos (Bickham, 1981). Em determinadas populações, altos índices de hibridismo podem estar ligados a alterações ambientais causadas pelo ser humano como a perda e sobreposição de habitats promovendo o encontro reprodutivo entre espécies anteriormente separadas (Lara-Ruiz, 2006).

Apesar do número reduzido de espécies, a utilização de sequências gênicas resolveu o relacionamento filogenético entre as tartarugas marinhas atuais, conforme descrito no início deste capítulo, além de contribuir para o entendimento de determinadas questões como a discussão sobre a elevação de C. agassizi ao status de espécie e o estudo sobre a evolução do habito alimentar espongívoro, bastante raro na 
natureza e exibido por tartarugas de pente, E. imbricata (Bowen, 2003; Naro-Maciel, 2008).

Ao analisar as populações de tartarugas verdes a partir de RFLP, Bowen et al. (1992) encontraram 14 haplótipos distintos, divididos entre as bases oceânicas Atlântico-Mediterrânea e Indo-Pacífica. Karl (1992), confirmou este padrão, proporcionando entretanto, uma descrição mais refinada entre a distância genética e a proximidade geográfica buscando explicações em possiveis conexões históricas entre tais populações e/ou fluxo gênico existente atualmente entre elas. Este último foi descrito como moderado, mediado pelos machos e igualmente relacionado à proximidade geográfica.

Ao soerguimento do Istmo do Panamá, há cerca de 3,5 milhões de anos, atribuise a divergência genética registrada entre as bases oceânicas e, portanto, a toda fauna marinha tropical que não tolera o ambiente dulcícola do Canal do Panamá. Ao sul, o regime termal rigoroso exibido pela corrente de Benguela foi descrito como mortal para a maioria das espécies tropicais. Contudo, tal regime termal não é instransponível às tartarugas verdes analisadas por Bourjea (2007) que registrou haplótipos característicos da base oceânica Atlântica disseminados no Canal de Moçambique, sul do Oceano Índico.

Sendo assim, os padrões de especiação e biodiversidade sofrem profunda influência do cenário geográfico que ocupam e a resolução de limites filogeográficos entre as populações tem se tornado essencial para o estabelecimento de prioridades de conservação e para a avaliação de estratégias de manejo para espécies ameaçadas.

Ainda, a determinação da origem de produtos confiscados durante inspeções ligadas ao combate do tráfico de animais silvestres é outra importante aplicação das ferramentas moleculares para fins conservacionistas (Roman e Bowen, 2000). A utilização de RFLP na detecção de carnes e ovos de tartarugas marinhas, mesmo quando cozidos, mostrou ser uma eficiente ferramenta, sendo utilizada pelo governo norte americano na inspeção de produtos suspeitos de serem oriundos destes animais (Moore, 2003).

\subsection{Estudos populacionais}

Todos os organismos vivem na natureza em populações que são caracterizadas por conjuntos de interações cooperativas ou inibitórias entre seus membros (Nei, 1975). 
Cada população exibe propriedades que transcendem as características próprias dos indivíduos que a compõem. A genética populacional busca compreender estrutura genética, ou seja, o conjunto de tipos e frequências de genes e genótipos existentes nas populações (Nei, 1975) e entender a causa da diferenciação existente entre aquelas que ocupam uma determinada área geográfica (Silva e Russo, 2000).

Populações naturais frequentemente são compostas por inúmeras subpopulações ou por indivíduos que se distribuem de maneira mais ou menos uniforme em determinada área. Estudos indicam haver uma estruturação pronunciada entre populações de tartarugas marinhas, com o avanço da idade e do desenvolvimento (Bowen, 2005). Na fase pelágica, filhotes de diferentes colônias de desova constituem agregamentos que exibem grande variabilidade genética, enquanto que agrupamentos de juvenis apresentam, ainda que discreto, um perfil genético que se tornará bastante pronunciado nas colônias de desova, durante a fase adulta. Cabe ressaltar, a importância desta complexa estruturação, visto que, em cada etapa de seu ciclo de vida, estes répteis poderão sofrer ameaças distintas que, resultarão em diferentes consequências para a manutenção da variabilidade que possuem (Bowen, 2005).

O grande desafio reside na definição dos estoques, visto que tais populações encontram-se isoladas geneticamente em determinadas fases da vida, nas praias de desova, mesclando-se em outras, em habitats de desenvolvimento e alimentação.

Os primeiros estudos populacionais realizados com tartarugas marinhas tinham por objetivo descrever, em termos genéticos, as áreas de desova. Bonhomme (1987) utilizaram eletroforese proteica para acessar colônias localizadas nos oceanos Atlântico, Pacífico e Índico, porém esta técnica não revelou diferenças significativas entre estas colônias.

Haplótipos de DNA mitocondrial, provenientes de 15 colônias localizadas nas diferentes bases oceânicas indicaram haver uma divisão bastante evidente entre dois grupos distintos de tartarugas verdes: (1) Atlântico e Mar Mediterrâneo e (2) Pacífico e Índico (Bowen, 1992). Este resultado é consistente com os limites geográficos e de temperatura que definem atualmente a distribuição desta espécie. Neste trabalho o modelo "natal homing", descrito anteriormente, foi sugerido como mais adequado para explicar o comportamento migratório exibido pelas fêmeas.

As colônias de Ilhas Ascensão e Suriname compartilham áreas de alimentação localizadas na costa brasileira, porém são completamente distintas, sob o ponto de vista genético (Bowen, 1992). Da mesma forma, praias de desova situadas ao sul e ao norte 
da grande barreira de coral da Austrália, caracterizadas por diferenças fixas em suas composições haplotípicas utilizam os mesmos recursos alimentares, distribuídos na costa deste país e do Mar de Coral (Norman, 1994; Dethmers, 2006).

Este mesmo padrão de estruturação geográfica foi descrito em outras regiões (Allard, 1994; Lahanas, 1994, Encalada, 1996; Bjorndal, 2006) e para outras espécies. C. caretta, a tartaruga cabeçuda, compartilha haplótipos, em diferentes frequências, entre bases oceânicas. Este fato é atribuído à distribuição e à tolerância a ambientes temperados exibida por esta espécie (Bowen, 1994). Em escala global, entretanto, "natal homing” foi corroborado para as populações do Atlântico (Bolten, 1998; Bowen, 2004) e do Pacífico (Hatase, 2002) assim como para E. imbricata, tartarugas de pente, amostradas na Austrália e no Caribe (Broderick, 1994; Bass, 2006; Velez-Zuazo, 2008).

Apesar da forte estruturação genética, em escala global, populações de $L$. olivacea, apresentam modesta estruturação, em termos regionais (Shanker, 2004; Lopez-Castro \& Rocha-Olivares, 2005) sendo o mesmo observado em tartarugas de couro, D. coriacea (Dutton, 1999, 2007), o que indica haver menor especificidade deste comportamento para estas espécies, talvez relacionado à ampla distribuição pelágica que exibem, durante a maior parte de suas vidas (Bowen, 2007).

Machos são raramente observados, e diferentemente das fêmeas, ocupam o habitat marinho durante todo seu ciclo de vida. Por este motivo, muito pouco é sabido a respeito de sua dispersão, comportamento migratório e de acasalamento, o que fez com que estudos sobre estes indivíduos fossem conduzidos, buscando complementar a estruturação genética descrita para as fêmeas.

“Natal homing” foi igualmente verificado para machos de tartarugas verdes, que retornam à mesma área de corte, geralmente próximas à região onde nasceram, durante as sucessivas estações reprodutivas (Karl, 1992; Limpus, 1993). Em contraste com as diferenças marcantes encontradas nos haplótipos mitocondriais em escala regional, os marcadores nucleares evidenciaram grande homogeneidade, apresentando alelos compartilhados por praticamente todas as populações analisadas por Karl (1992). Estimativas de fluxo gênico, para colônias de mesma base oceânica apontam os machos como responsáveis por este intercâmbio gênico. Apesar de apresentar comportamento migratório, esta homogeneidade, confirmada por Fitzsimmons (1997b) pode ser resultante de cópulas em corredores migratórios, áreas de alimentação ou em sítios de acasalamento, frequentados por fêmeas de duas ou mais colônias distintas. Através da análise de microssatélites, Roberts (2004) confirmou haver pouca estruturação genética 
entre populações de tartarugas verdes dentro das diferentes bases oceânicas. Contudo, confirmam a clara divisão entre Atlântico e Pacífico.

Estes trabalhos indicam haver uma importante relação entre o comportamento filopátrico e a estruturação exibida por populações de tartarugas marinhas. Da mesma forma que “natal homing” está diretamente ligado às migrações reprodutivas, o mesmo poderia ser aplicado a outras etapas do desenvolvimento destes quelônios. Diferentes testes foram conduzidos por Bowen (2004) a fim de confirmar que este modelo aplicase também à fase juvenil das tartarugas cabeçudas (Caretta caretta), que utilizam regiões adjacentes às praias onde nasceram para se alimentar. A segregação de áreas de alimentação, que reflete o padrão filogeográfico descrito para as áreas de desova, corrobora tal hipótese para juvenis de tartarugas verdes (Bass, 2006).

Inúmeros estudos têm sido conduzidos para acessar a composição demográfica de áreas de alimentação, cujo principal interesse é entender os mecanismos responsáveis pelo recrutamento dos animais para estas regiões e as rotas migratórias por eles utilizadas (Sears, 1995; Bass e Witzell, 2000; Luke, 2004; Bass, 2006; Naro-Maciel, 2007, Dutton, 2008; Velez-Zuazo, 2008). Sabe-se que tais regiões abrigam estoques mistos, provenientes de diferentes áreas de desova (Lahanas, 1998; Dias-Fernandez, 1999 Bass, 2004; Naro-Maciel, 2007; Dutton, 2007).

Para determinar a composição genética de um sítio de alimentação situado nas Bahamas, Lahanas (1998) amostrou 80 juvenis e, como resultado, encontrou um estoque misto, oriundo de múltiplas áreas de desova, com 79,5\% dos animais provenientes do Caribe Ocidental e 12,9\% do Caribe Oriental, sendo tais contribuições proporcionais ao tamanho das respectivas colônias. Diferentemente, os resultados encontrados a partir da análise de juvenis em áreas de alimentação da costa da Flórida, indicam a distância geográfica como fator determinante na composição haplotipica encontrada (Bass e Witzell, 2000). Em Barbados, evidências de multiplas origens foram encontradas por Luke (2004) que registrou contribuições praticamente iguais provenientes das Ilhas Ascensão, Costa Rica e Flórida, não encontrando, entretanto, qualquer influência significativa do tamanho ou distância existente entre a área de estudo e os estoques contribuintes, atribuindo seus resultados ao complexo padrão de giros e correntes oceânicas como responsável pelo recrutamento de juvenis provenientes das colônias mais distantes.

Em trabalhos mais recentes, pesquisadores buscam possíveis combinações entre os fatores acima descritos, na tentativa de explicar os padrões de estruturação genética 
encontrados nestas regiões (Bass, 2006; Naro-Maciel, 2007). Muitas regiões amostradas, apresentam ainda haplótipos denominados “orfãos” por terem suas áreas de origem ainda desconhecidas, o que indica necessidade de aprofundamento nas investigações a fim de definir de quais praias de desova esses animais são provenientes. Por outro lado, tais haplótipos podem ser oriundos de regiões ja estudadas, cuja amostragem não forneceu um panorama genético completo de modo que, uma ampla amostragem das colônias estoques ainda é prioritária (Formia, 2002).

O entendimento da composição genética das áreas de alimentação permite aos pesquisadores monitorar o status de tais populações, fornecendo dados para a avaliação dos estoques e do complexo ciclo de vida que estes répteis exibem. Por exibir grande homogeneidade genética nas praias de desova, agregações de alimentação contêm a variabilidade genética crucial à manutenção destas espécies e entender a conexão entre tais estoques assim como a estruturação genética existente nestes, permite a elaboração de estratégias efetivas para a conservação de tais espécies. 


\section{Capítulo 2}

\subsection{Cananéia: Estruturação e Análise Populacional utilizando DNA mitocondrial}

\subsubsection{Introdução}

O entendimento da fase juvenil e os padrões de movimento exibidos nessa etapa do ciclo de vida são questões intrigantes no estudo dos vertebrados marinhos (Norman, 1994). Animais de pequeno porte, que exibem padrões migratórios envolvendo longas distâncias e que utilizam habitats pouco compreendidos são dificilmente monitorados por estudos biológicos.

Movimentos de longa distância foram inicialmente monitorados através da marcação destes animais (Carr, 1978), utilizando-se anilhas metálicas e, através de suas recapturas, tornando possível acessar informações sobre deslocamento, encalhes, distribuição e taxas de crescimento (Balazs, 2000). A marcação e recaptura permite ainda o acompanhamento do desenvolvimento de doenças, ferimentos, tumores ou mesmo seu reestabelecimento, em casos em que os animais foram liberados após reabilitação.

$\mathrm{O}$ advento da tecnologia de telemetria satelital permitiu o entendimento de alguns aspectos comportamentais das tartarugas durante esses movimentos de longa distância (Godley, 2002), como por exemplo, diferentes padrões de migração ao longo da costa ou cruzando o oceano aberto, a velocidade com que viajam e o comportamento de mergulho durante tais deslocamentos (Rice, 2008). Por permitir o acesso a informações sobre padrões de distribuição espacial e temporal, rotas migratórias resultantes destes estudos podem ser integradas a dados de sensoriamento remoto a fim de elucidar as condições oceanográficas que podem ter influência sobre o uso de habitat das tartarugas marinhas (Seminoff, 2008). Apesar das informações valiosas obtidas através deste método, grandes lacunas impedem o completo entendimento do comportamento migratório exibido por neonatos e juvenis por dificuldades logísticas e financeiras no desenvolvimento de trabalhos que envolvam tal técnica, pois além do alto custo dos transmissores, o pequeno porte dos animais, muitas vezes impede a utilização destes equipamentos, podendo comprometer seu desenvolvimento e deslocamento. 
Atualmente, entretanto, marcadores moleculares têm sido utilizados para elucidar diferentes aspectos da história de vida de juvenis de organismos marinhos migratórios como salmões, baleias e tartarugas marinhas (Sato, 2004; Pastene, 2006; Dutton, 2008). Estas ferramentas permitem acessar a repartição genética entre populações geograficamente isoladas, definir unidades significamente evolutivas além de serem úteis na elaboração de propostas de manejo e conservação (Moritz, 2002).

O entendimento da distribuição das populações dentro de seus habitats não é apenas vital para a implementação de estratégias efetivas de conservação destas espécies, mas também contribui significativamente para a compreensão de aspectos fundamentais de sua biologia e ecologia (Norman, 1994).

\subsubsection{DNA mitocondrial}

O DNA mitocondrial tem sido amplamente utilizado em estudos ecológicos e evolutivos de tartarugas marinhas (Norman, 1994; Bowen e Karl, 1997; Bass e Witzell, 2000; Formia, 2002; Bass, 2004; Bowen, 2005; Bjorndal 2006; Naro-Maciel, 2007). Exceto em algumas espécies, o genoma mitocontrial é formado por uma molécula circular de DNA dupla fita de aproximadamente 15000 a 20000 pares de bases (pb), contendo em geral 13 genes codificadores de proteínas, 22 genes codificadores de tRNA (RNA transportador), 2 genes de rRNA (RNA ribossômico) e uma região de 1000 pb, responsável pelo início da replicação e transcrição denominada região controle (Tarbelet, 1996). A região controle é também denominada "D-loop” nos vertebrados. Este material genético é transmitido, geralmente sem que ocorra recombinação, pela linhagem materna, o que possibilita seu uso no traçado de uma filogenia matrilinear. Sua utilização é especialmente facilitada por se tratar de uma região amplamente conhecida que exibe taxas evolutivas equivalentes a 5 a 10 vezes aquelas apresentadas pelo genoma nuclear (Brown, 1982). Embora para estas regiões do DNA, os quelônios não exibam taxas tão altas de mutação, este material genético apresenta um nível de variabilidade adequado para a realização de estudos populacionais (Avise, 1992).

Diferenças nas frequências de sequências de DNA mitocondrial, denominadas haplótipos, permitem a distinção entre colônias de desova incluindo aquelas compostas de tartarugas verdes (Encalada, 1996). A análise desses haplótipos permite ainda, a reconstrução de conexões entre áreas de alimentação e desova, podendo ser utilizadas 
na construção de um cenário filogeográfico, a partir da distribuição geográfica e padrão histórico de dispersão destes animais (Avise, 1995). Os haplótipos nos informam também a respeito de cruzamentos entre membros de espécies distintas (Karl e Bowen 1995; Lara-Ruiz,. 2006), o que pode vir a modificar a história evolutiva destes animais.

As populações de tartarugas marinhas estudadas apresentam um padrão estrutural, no qual alguns haplótipos são geralmente específicos para determinadas regiões geográficas, fazendo com que as praias de desova representem unidades genéticas descontínuas. A perda de tais unidades representa um declínio na diversidade genética da espécie em questão e estas informações são bastante valiosas no entendimento de seu status atual, podendo ser utilizadas na elaboração de estratégias que efetivamente contribuam para sua conservação.

\subsection{2 Áreas de alimentação}

Áreas de desova de tartarugas marinhas localizadas nos Oceanos Atlântico, Pacífico e Índico foram amplamente estudadas (Bowen, 1992; Lahanas 1994; Encalada 1996, Bowen 2007). Atualmente, os trabalhos desenvolvidos nestas regiões têm voltado sua atenção para o refinamento das informações obtidas através da ampliação de amostragens, de estações e anos amostrados, além da utilização de outros marcadores (Bass, 1999; Roberts, 2004; Dethmers, 2006; Lee, 2007; Monzón-Argüello, 2008, Roden, 2008; Fig. 04).

Áreas de alimentação foram mais recentemente acessadas devido a maior dificuldade de amostragem, menor garantia de obtenção de amostras, além dos altos custos envolvidos nestes estudos. Estas áreas foram descritas como estoques mistos, reunindo indivíduos provenientes de colônias de desova distintas (Luke, 2004; Bass, 2006; Dutton, 2008; Figura 04). Ao analisar colônias de tartarugas verdes do Oceano Atlântico e do Mar Mediterrâneo, Encalada (1996) reuniu os haplótipos encontrados, em dois grandes grupos, de acordo com o isolamento geográfico e a independência demográfica: o primeiro grupo inclui a população do Caribe Ocidental e um único sítio de desova do Mar Mediterrâneo e, ao segundo grupo pertencem as populações do Caribe Oriental, Atlântico Sul e colônias da Costa Ocidental da África (Fig. 05). 


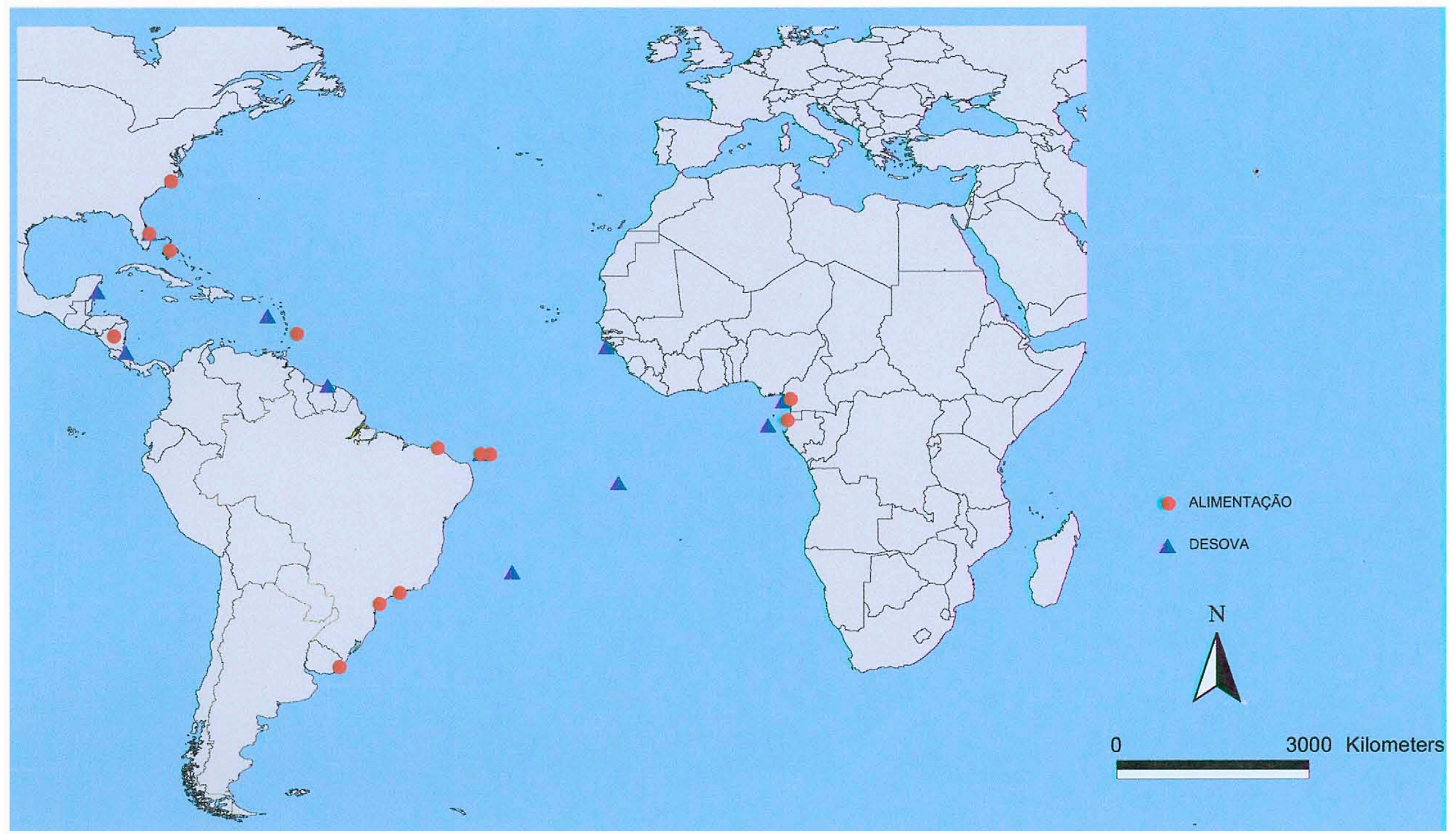

Figura 04. Mapa da distribuição das áreas de alimentação e desova localizadas no Oceano Atlântico. 


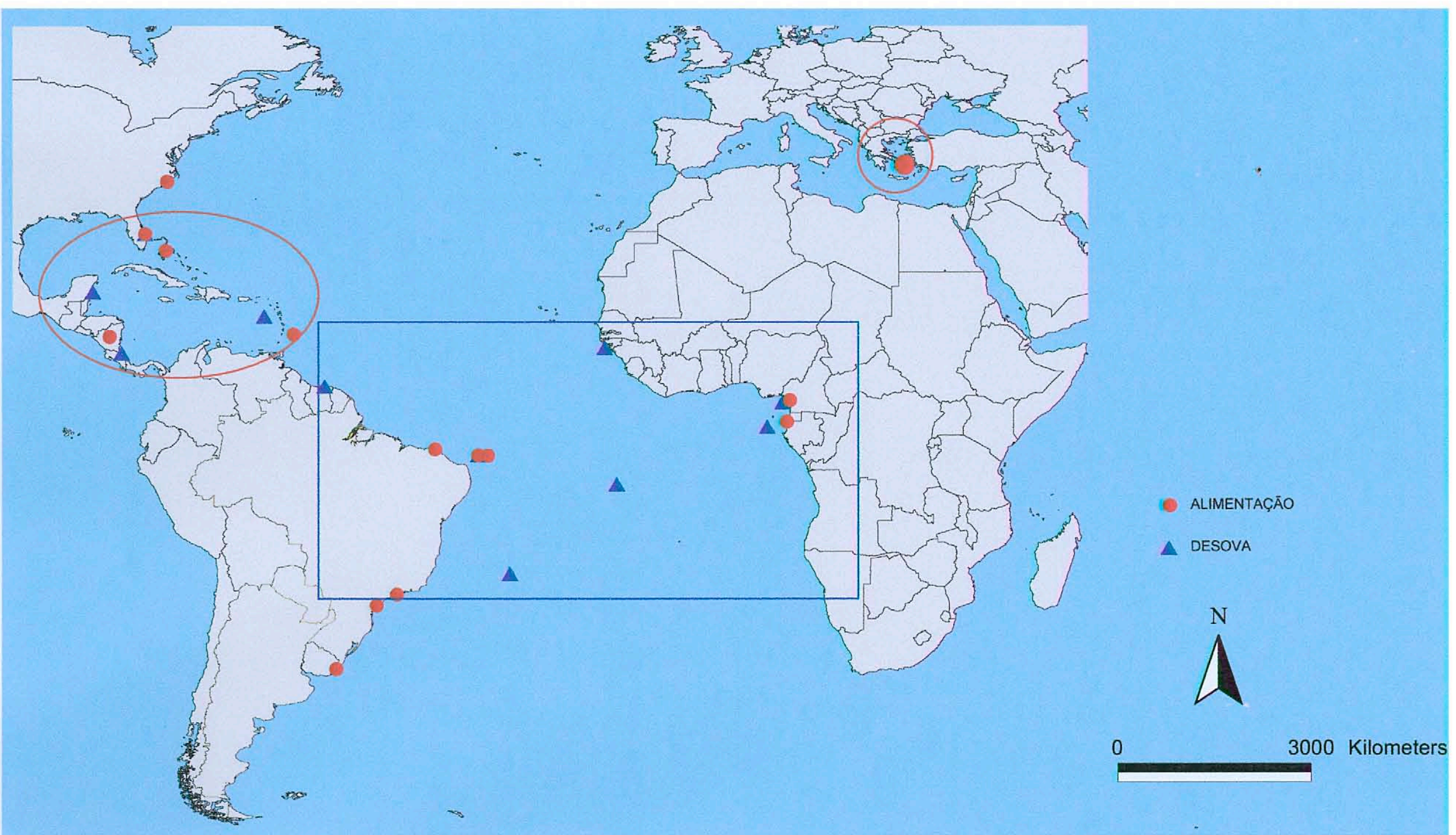

Figura 05. Mapa da distribuição filogeográfica das populações de desova analisadas no Oceano Atlântico (Adaptado de Encalada, 1996). 
Recentemente áreas de alimentação e desenvolvimento de tartarugas verdes na costa uruguaia foram acessadas por Caraccio (2008) que encontrou um estoque misto, muito similar aquele registrado para Ubatuba e composto de animais provenientes de colônias localizadas nas Ilhas Ascensão, Suriname, Ilha Aves, Guiné Bissau, Guiné Equatorial, Atol das Rocas, São Tomé, Príncipe e México.

Ao estudar áreas de alimentação localizadas em Ubatuba (SP) e Almofala (CE), Naro-Maciel (2007) confirmou a existência de estoques mistos em áreas de alimentação localizadas na costa brasileira, contribuindo significativamente para o entendimento da conectividade entre sítios de alimentação e de desova localizados no Atlântico Sul Ocidental, sendo o único estudo sobre composição genética em áreas de alimentação no Brasil.

Da mesma maneira que as áreas descritas acima, os demais sítios de forrageio brasileiros encontram-se dispersos ao longo de toda a costa, do Ceará ao Rio Grande do Sul, com maior agrupamento de indivíduos atraídos pela disponibilidade de alimento, em regiões caracterizadas por costões rochosos, parcéis, lajes, ilhas e ilhotas, substratos para a proliferação de algas.

O Complexo Estuarino Lagunar de Cananéia/Iguape abriga uma importante área de alimentação de juvenis de tartarugas verdes, que ocorrem em abundância durante o ano todo (Bondioli, 2008), sendo registrada, entre os anos de 2007 e 2008, uma média de 120 animais (Dados não publicados). A presença desses indivíduos nessa área é principalmente atribuída à grande disponibilidade de algas e angiospermas marinhas, alimento de sua preferência e que ocorrem em grandes bancos distribuídos ao longo do estuário (Guebert, 2008). Estima-se, através de dados de marcação e recaptura, que estes animais podem permanecer na região por períodos superiores a um ano, o que pode indicar a sua utilização por esta espécie como área de desenvolvimento (Dados não publicados).

Estudos dedicados a áreas de alimentação tratam principalmente de ecologia alimentar (Bjorndal, 2000), telemetria (Hatase, 2002) e uso de hábitat (Godley, 2002). Estas áreas são de fundamental importância, uma vez que são utilizadas pelas tartarugas durante a maior parte da suas vidas e são compostas, na maioria dos estudos, por um estoque misto, recebendo animais de diferentes áreas de desova. Esta mistura pode trazer informações valiosas sobre a composição populacional, o fluxo gênico e a filopatria, além de ser fundamental na elaboração de qualquer plano de manejo, tanto para a espécie em questão, como para a região do estudo. 


\subsection{Objetivos}

O presente trabalho teve por objetivo descrever a varialibidade e estruturação genética de tartarugas verdes (Chelonia mydas) da região de Cananéia, com base no DNA mitocondrial, buscando:

- Identificar a composição haplotípica encontrada na região de Cananéia, analisando sua diversidade;

- Identificar as praias de desova que contribuem para a composição desta área de alimentação;

- Detectar e analisar possíveis variações temporais entre as amostras coletadas nos anos de 2005, 2006, 2007 e 2008;

- Detectar e analisar possíveis variações sazonais entre as diferentes estações amostradas (três estações de verão e quatro estações de inverno);

- Avaliar a diversidade genética presente em Cananéia, em relação às outras áreas de alimentação do Oceano Atlântico e entre aquelas localizadas no Atlântico Sul Ocidental.

\subsection{Metodologia}

\subsection{1 Área de Estudo}

A região de Cananéia localiza-se no litoral sul do Estado de São Paulo (2501'27”S; 4755’56”O; Fig. 06). Compondo parte do Complexo Estuarino-lagunar de Iguape-Cananéia-Guaraqueçaba (Lagamar), é uma das Reservas de Biosfera declaradas pela UNESCO, em 1991, e recebeu o título de Patrimonio Natural da Humanidade, em 2000, representando uma das regiões costeiras com ecossistemas mais importantes de nosso país (Diegues, 1987). Segundo a IUCN (1984), essa região está entre os cinco estuários considerados como pouco degradados, prioritários para a conservação de acordo com a Estratégia Mundial de Conservação. 


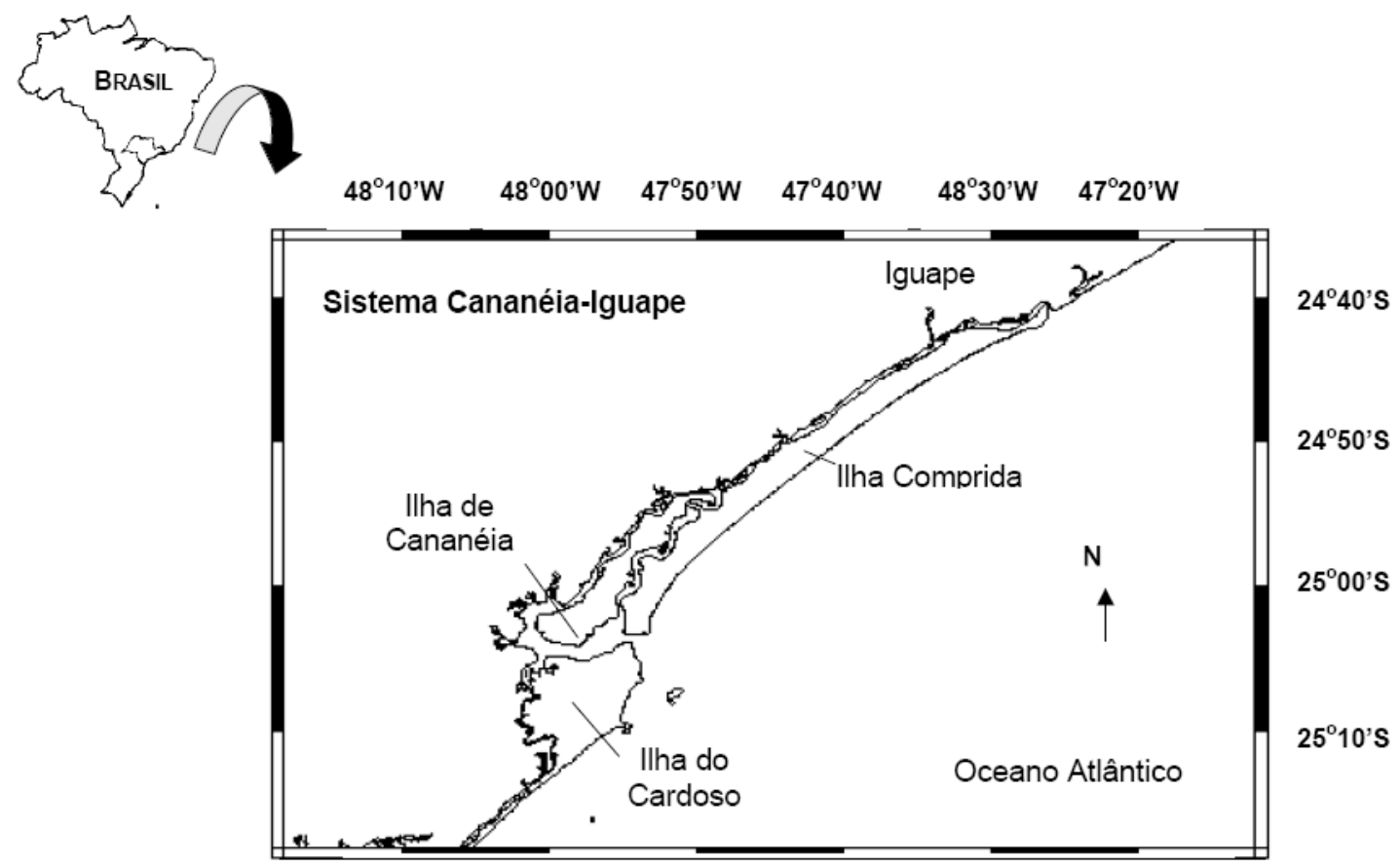

Figura 06. Complexo Estuarino Lagunar de Cananéia/Iguape (Cunha-Lignon, 2001).

Protegida do mar aberto pela Ilha Comprida e pela Ilha do Cardoso (ambas pertencentes a Áreas de Proteção Ambiental Estadual e Federal, respectivamente), a região é formada por um conjunto de baías, morros isolados, desembocaduras de rios e vários tipos de ilhas e ilhotas. A circulação do sistema é dirigida principalmente pela ação da onda de maré e pela contribuição de água doce dos rios, embora sofrendo em algumas ocasiões influências eólicas; a distribuição da salinidade na região varia com o tempo em função da água doce acumulada (Miyao, 1986). A onda de maré que entra pela Barra de Cananéia e Barra de Icapara, divide-se em duas porções que seguem para pontos diferentes: uma em direção ao Mar Pequeno e outra que atinge o Mar de Cubatão, através da Baía de Trapandé (Besnard 1950; Miniussi 1959). Nos canais banhados por água salobra e na zona costeira interna predominam os manguezais. A temperatura média anual é de $21,2^{\circ} \mathrm{C}$ e a variação média diária e de $6,7^{\circ} \mathrm{C}$. O clima da região é caracterizado pelo predomínio de massas de ar tropical no verão e discreto predomínio de massas de ar polar no inverno (Occhipinti, 1963). Diferentes ecossistemas como mata de restinga, a Mata Atlântica, manguezais, praias, costões rochosos e o ambiente marinho são encontrados na região que abriga grande diversidade.

A região de Cananéia apresenta grande abundância de peixes. Amostragens realizadas em 13 localidades do Complexo Estuarino-Lagunar de Iguape-Cananéia 
revelaram a ocorrência de 132 espécies de peixe, distribuídas em 50 famílias (Maciel, 2001), sendo que boa parte é proveniente de regiões oceânicas, ocorrendo apenas em determinadas épocas do ano.

Essa riqueza de recursos disponíveis proporciona uma importante atividade econômica para a região, principalmente para a comunidade local de pescadores que utiliza uma armadilha de pesca artesanal, conhecida como cerco-fixo de pesca (Mendonça e Katsuragawa, 2001). Esta armadilha composta por taquaras e mourões fica situada à margem do estuário. A espia, que se estende da margem até a casa do peixe é colocada perpendicularmente à direção da maré e sua função é conduzir os cardumes até o gancho, onde ficam retidos tendo como único destino, a casa do peixe, uma espécie de tanque onde os peixes permanecem armazenados (Fig. 07). A retirada dos peixes do cerco, conhecida como despesca, é efetuada por no mínimo dois pescadores que, com o auxílio de uma rede, realizam uma espécie de arrasto dentro da casa do peixe, retirando todo o pescado contido dentro dela. Além dos peixes, é comum a eventual entrada de outros animais como as tartarugas marinhas (Fig. 08), que ficam retidos vivos sem nenhum dano, até que se realize a despesca. Nesta ocasião em que os animais são liberados, o apoio dos pescadores, possibilitou a coleta de dados e amostras de tecidos destes animais (Nagaoka, 2008).

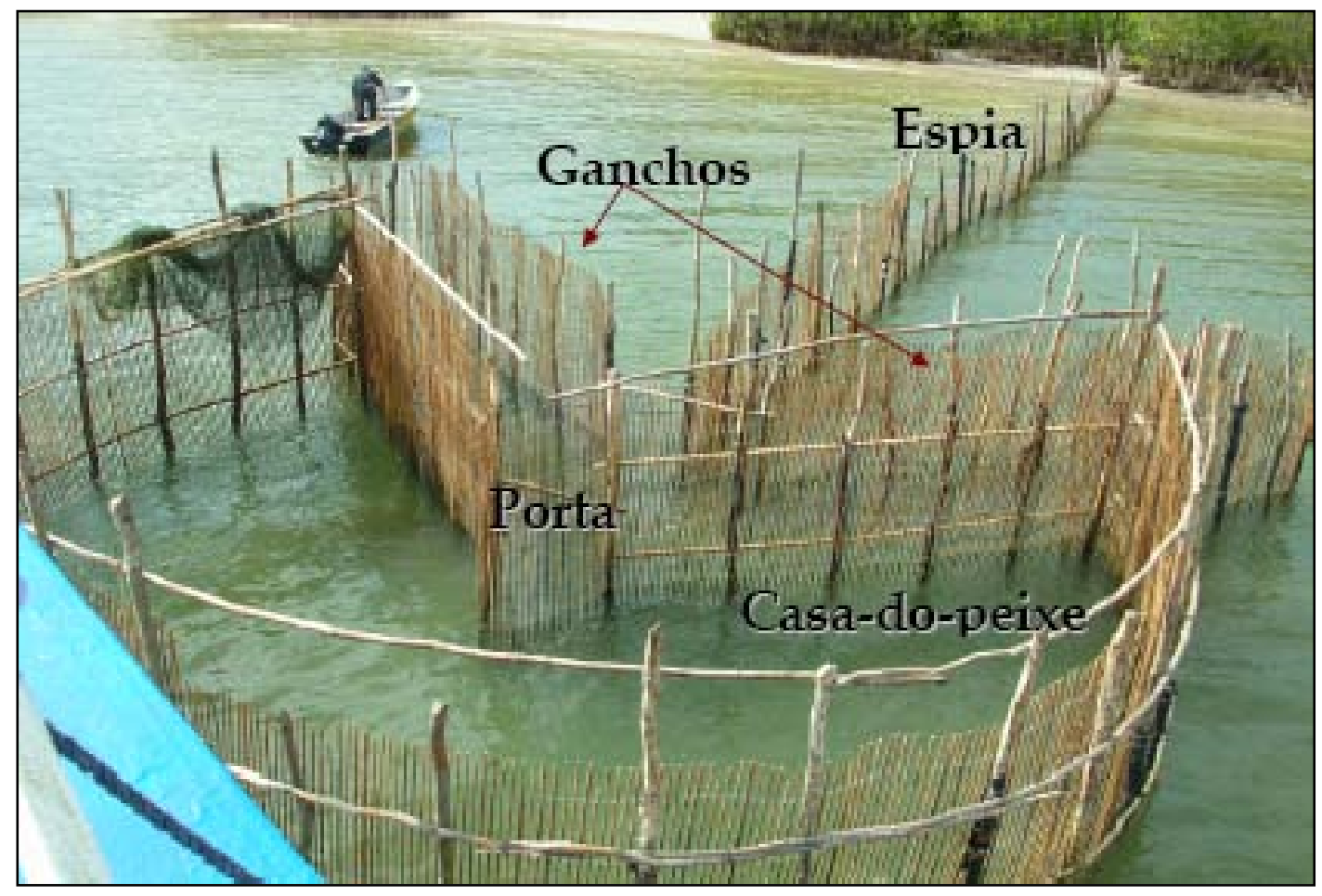

Figura 07. Cerco-fixo de pesca, armadilha artesanal que captura incidentalmente tartarugas marinhas na região de Cananéia (Foto: Flávia C. de Oliveira). 


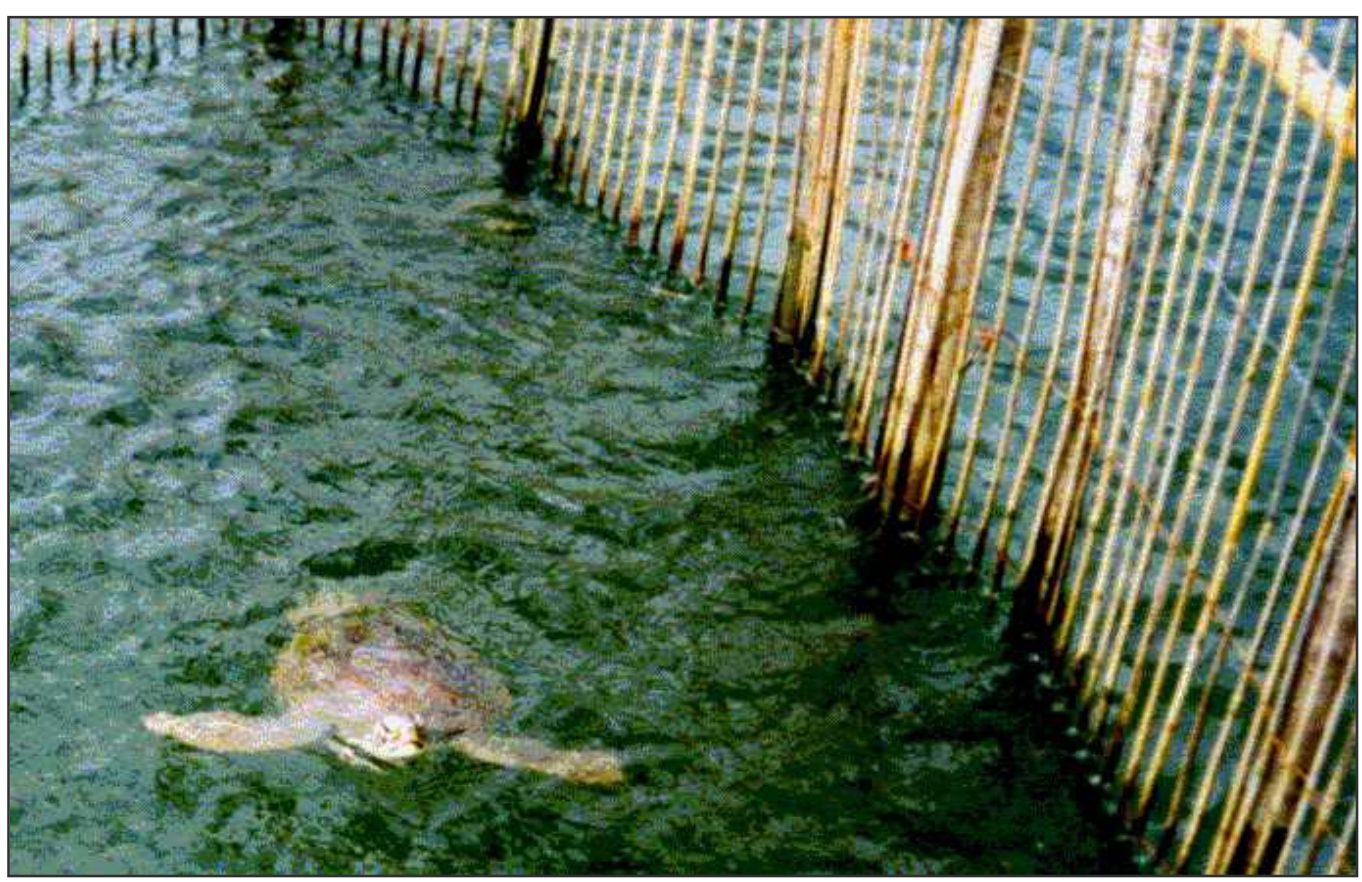

Figura 08. Chelonia mydas capturada incidentalmente no cerco-fixo de pesca (Foto: Jaqueline Frois).

\subsubsection{Coleta de Tecidos}

Sete temporadas de coleta foram realizadas no presente estudo. Durante as mesmas, monitoramentos das armadilhas de pesca foram realizados com o intuito de amostrar os animais capturados incidentalmente neste petrecho de pesca. Além disto, e com o objetivo de implementar o banco de dados, monitoramentos das praias da região (Ilha Comprida e Ilha do Cardoso) foram semanalmente realizados durante as temporadas de coleta, à procura de carcaças trazidas pela ação da maré, ou animais debilitados encontrados encalhados.

Ao capturar cada animal foi realizada a biometria do mesmo, segundo o método adotado pelo Tamar-ICMBio, onde são coletados data, hora, local e forma de captura, além da tomada de medidas de comprimento curvilíneo da carapaça (CCC), largura curvilínea da carapaça (LCC) e peso (TAMAR, 2008). Foram verificada a presença de parasitas, epibiontes, fibropapilomas e qualquer tipo de ferimento. Em seguida, foi realizada a marcação, com a utilização de anilhas metálicas (National Band and Tag CO) cedidas pelo Projeto Tamar-ICMBio, a fim de identificar cada animal evitando coletas posteriores de tecido de um mesmo indivíduo, caso ocorra sua recaptura. Da mesma forma, cada tartaruga foi fotoidentificada, através da tomada de registros fotográficos dos padrões de escamas pós-orbitais direitas e esquerdas assegurando 
assim, não haver reamostragem de um mesmo indivíduo (Fig 09).

Cada animal capturado teve pequenos fragmentos de pele de aproximadamente 6 mm de diâmetro retirados com o auxílio de uma pinça cirúrgica e lâminas estéreis, a fim de evitar contaminação. Após a retirada, as amostras foram estocadas em microtubos contendo etanol 90\%, segundo o método descrito por Dutton (1995). A coleta de fragmentos de tecidos das carcaças encontradas durante o monitoramento de praias foi realizada da mesma forma que para os animais capturados, porém precauções como a retiradas de fragmentos de regiões menos afetadas pela decomposição foram tomadas a fim de obter amostras mais frescas quanto possíveis. Alíquotas de todas as amostras coletadas foram depositadas na coleção de tecidos herpetológicos do Museu de Zoologia da Universidade de São Paulo.

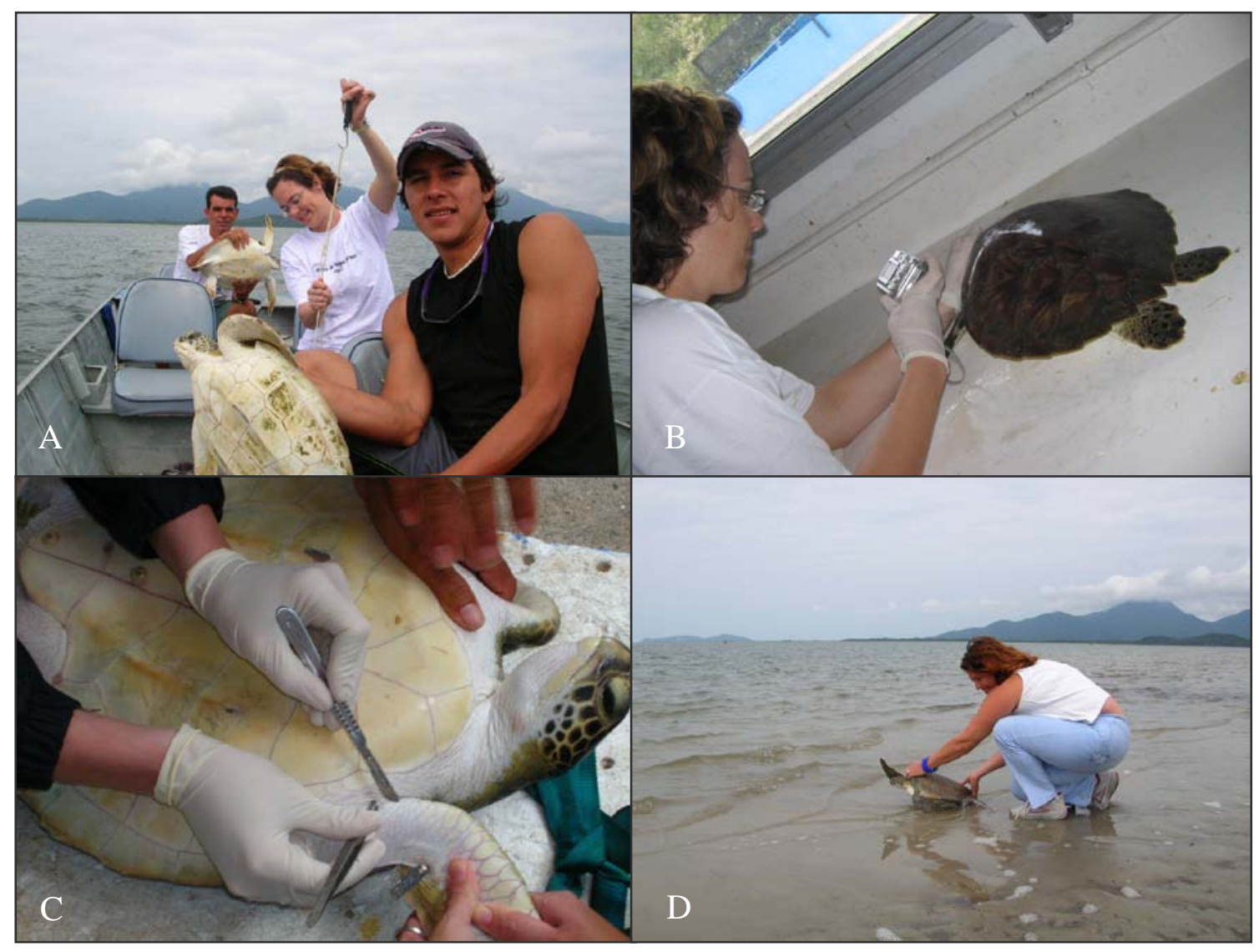

do animal (Fotos: Projeto Tartarugas - IPeC). 


\subsubsection{Processamento das amostras}

Para cada digestão, foi utilizado um fragmento de aproximadamente $3 \mathrm{~mm}$ de tecido cutâneo de $C$. mydas submetido a uma solução de lise nuclear, contendo $10 \mu \mathrm{l}$ de Proteinase K (10mg/ml) e incubado a $55^{\circ} \mathrm{C}$ durante uma noite (Sambrook, 2001). A extração foi realizada através do kit promega (Wisard ${ }^{\circledR}$ ) e seu protocolo para extração de DNA de tecido animal recomendado pelo fabricante sem qualquer alteração.

Para a amplificação do fragmento correspondente ao tRNA-Pro+D-loop do DNA mitocondrial, utilizou-se o par de iniciadores LTCM2 e HDCM2 descritos por Lahanas (1994).

\section{LDCM2 5’ - (CGGTCCCCAAAACCGGAATCCTAT-3’) \\ HDCM2 5'-(GCAAGTAAAACTACCGTATGCCAGGTTA-3’)}

As reações foram preparadas contendo 1X Tampão da Taq polimerase, 1,5 mM de $\mathrm{MgCl}_{2}, 0,25 \mathrm{mM}$ de dNTPs, 0,5 $\mu \mathrm{Mol}$ de cada primer, 0,5 U de Taq polimerase e aproximadamente 15ng de DNA e $\mathrm{H}_{2} \mathrm{O}$ para completar o volume final da reação (25 $\left.\mu \mathrm{l}\right)$. Os ciclos utilizados se iniciam a $94^{\circ} \mathrm{C}$ por 5 minutos, seguidos de 35 ciclos de $94^{\circ} \mathrm{C}$ por 45 segundos, $55^{\circ} \mathrm{C}$ por 30 segundos e $72^{\circ} \mathrm{C}$ por 45 segundos, seguidos de uma extensão de $72^{\circ} \mathrm{C}$ por 3 minutos.

Os produtos de PCR foram purificados através do Kit Gene Clean II, de acordo com as recomendações dos fabricantes, e as reações de sequenciamento foram realizadas no Centro de Estudos do Genoma Humano da Universidade de São Paulo, através do método dideoxiterminal descrito por Sanger (1977). Este método de seqüenciamento consiste no uso de moléculas fluorescentes com quatro diferentes cores ligadas aos didesoxinucleotídeos (uma cor para cada um). Utilizando o equipamento MegaBACE 1000 (GE Healthcare), as reações foram preparadas com o kit MegaBACE DYEnamic ET Dye Terminator Kit e seguiram o seguinte protocolo: $4 \mu \mathrm{l}$ de Mega BACE Mix, 0,6 $\mu$ l de cada primer $(5 \mu \mathrm{M})$, 40ng de produto de PCR purificado e $\mathrm{H}_{2} \mathrm{O}$ para completar o volume final da reação $(10 \mu \mathrm{l})$. Foram utilizados trinta e cinco ciclos de $95^{\circ} \mathrm{C}$ por 20 segundos, $55^{\circ} \mathrm{C}$ por 15 segundos e $60^{\circ} \mathrm{C}$ por um minuto, após os quais a reação foi mantida a $10^{\circ} \mathrm{C}$. Em seguida, as reações foram purificadas em sephadex G50 
e aplicadas no Megabace 1000 sob as seguintes condições: injeção (2kv - 60 segundos) e corrida ( $8 \mathrm{kv}$ - 140 minutos).

Por fim, os resultados do seqüenciamento foram analisados pelo software Sequence Analyser 3.0 (GE Healthcare ${ }^{\circledR}$ ) com basecaller Cimarron 3.12 (GE Healthcare $\left.{ }^{\circledR}\right)$.

\subsubsection{Análise de dados}

O alinhamento das sequências obtidas foi conduzido com o auxílio do programa BioEdit 5.0.6 (Hall, 2001). Os haplótipos observados foram classificados de acordo com aqueles depositados no banco de dados do Archie Carr Center for Sea Turtle Research (ACCSTR) para tartarugas verdes do Oceano Atlântico e GeneBank (http://ncbi.nlm.nih.gov/).

Estimativas de diversidade haplotípica e nucleotídica foram geradas através do programa Arlequin 3.0.1 (Excoffier, 2006). O programa TCS 1.21 (Clemente, 2000) foi utilizado para gerar uma rede haplotípica, baseada em estatística parcimoniosa a fim de determinar as relações entre os haplótipos registrados.

Análises de subconjuntos desta população foram realizadas através de testes exatos de diferenciação com o intuito de observar variações anuais (2005, 2006, 2007 e 2008) e sazonais (estações de verão e inverno). Estes testes foram realizados utilizandose cadeia de Markov de 10000 passos com dememorização de 1000 passos implementados pelo programa Arlequin 3.01 (Excoffier, 2006). Para a análise temporal utilizou-se $2005(n=44), 2006(n=51), 2007(n=76)$ e $2008(n=54)$. Para a análise sazonal utilizou-se três estações de verão (outubro a março; $n_{v 1}=11, n_{v 2}=61, n_{v 3}=15$ ) e quatro estações de inverno (abril a setembro; $n_{i 1}=42, n_{i 2}=10, n_{i 3}=44, n_{i 4}=30$ ). Estas amostras foram também submetidas a testes do $\mathrm{X}^{2}$ implementados pelo programa CHIRXC (Zaykin e Pudovkin, 1993) com o objetivo de avaliar a homogeneidade existente entre elas.

Testes exatos de diferenciação populacional (Raymond e Rousset, 1995) foram igualmente executados a fim de estimar diferenças entre a amostra e aquelas descritas na literatura para outros sítios de alimentação presentes no Oceano Atlântico (Tabela 01). Estes testes foram realizados da mesma forma e sob os mesmos parâmetros que aqueles aplicados para acessar diferenças entre subconjuntos da amostra total. Da 
mesma forma, a homogeneidade foi testada para estes sítios, através de testes do $\mathrm{X}^{2}$ (CHIRXC; Zaykin e Pudovkin, 1993) e comparações entre os valores de Fst e Фst obtidos através do programa Arlequin 3.0.1 (Excoffier, 2006) para estas amostras.

Tabela 01. Áreas de alimentação utilizadas neste estudo, números amostrais e referências.

\begin{tabular}{ccc} 
Área de alimentação & N & Referência \\
\hline Carolina do Norte & 106 & Bass, 2006 \\
Florida & 62 & Bass \& Witzell, 2000 \\
Bahamas & 79 & Lahanas, 1998 \\
Barbados & 60 & Luke, 2004 \\
Nicaragua & 60 & Bass, 1998 \\
Almofala & 117 & Naro-Maciel, 2007 \\
A. Rocas/ F. Noronha & 23 & Bjorndal, 2006 \\
Ubatuba & 113 & Naro-Maciel, 2007 \\
Uruguai & 144 & Caraccio, 2008 \\
Corisco & 239 & Formia, 2002 \\
Golfo da Guiné & 395 & Formia, 2002
\end{tabular}

A análise de variância molecular (AMOVA) foi conduzida a fim de determinar como se comporta a variação molecular entre os sítios de alimentação do Atlântico. Especificamente para as áreas de alimentação pertencentes ao Atlântico Sul Ocidental, as mesmas análise foram realizadas e, para todas elas, as distâncias foram calculadas usando-se o modelo de substituição nucleotídica conhecido como Kimura-2 parâmetros (Kimura, 1980) e estatística “ $F$ ” convencional, ambos implementados pelo programa Arlequin 3.01 com 10000 permutações a fim de acessar a significância do valor de $P$ a eles associados.

\subsection{Resultados}

Fragmentos de 481 pares de base da região controladora do DNA mitocondrial foram sequenciados em 219 indivíduos, amostrados durante sete estações, em quatro anos consecutivos (2005 a 2008). Deste total, 202 (92\%) foram capturadas em 
amadilhas de pesca, 17 (8\%) foram coletadas a partir de carcaças encontradas na praia. Vinte tartarugas amostradas apresentaram fibropapilomas (9\%) e amostras de 12 animais não puderam ser amplificadas, dado o alto grau de putrefação das carcaças amostradas. Ainda, 27 indivíduos foram recapturados, sendo que o maior intervalo entre capturas registrado foi de 17 meses.

Estes animais foram classificados como juvenis, por apresentar CCC variando entre 31 e $49 \mathrm{~cm}(x=38,4 \pm 4.32 \mathrm{~cm})$ e LCC variando entre 28,5 e $43 \mathrm{~cm}(x=36 \pm$ $4.06 \mathrm{~cm})$. O peso variou entre 2,5 e $16 \mathrm{~kg}(\mathrm{x}=5,95 \pm 2,21 \mathrm{~kg})$, sendo este dado coletado apenas a partir de animais capturados vivos. Apenas cinco indivíduos (2\%) foram registrados com CCC superiores a $50 \mathrm{~cm}$.

Um total de dez haplótipos, definidos a partir de quatorze sítios polimórficos (onze transições e três transversões) foi registrado entre os indivíduos amostrados, todos descritos anteriormente para áreas de desova. O haplótipo mais freqüente na amostra foi CM-8 (63\%), seguido de CM-5 (26\%). Os demais haplótipos registrados (CM-01, CM6, CM-9, CM-10, CM-24, CM-32, CM-36 e CM-45) contribuíram em freqüências menores que 5\% (Fig 10). Os valores da diversidade haplotípica e nucleotídica encontrados para Cananéia foram de $\mathrm{H}=0,5393 \pm 0,0300$ e $\pi=0,002138 \pm 0,001588$. 


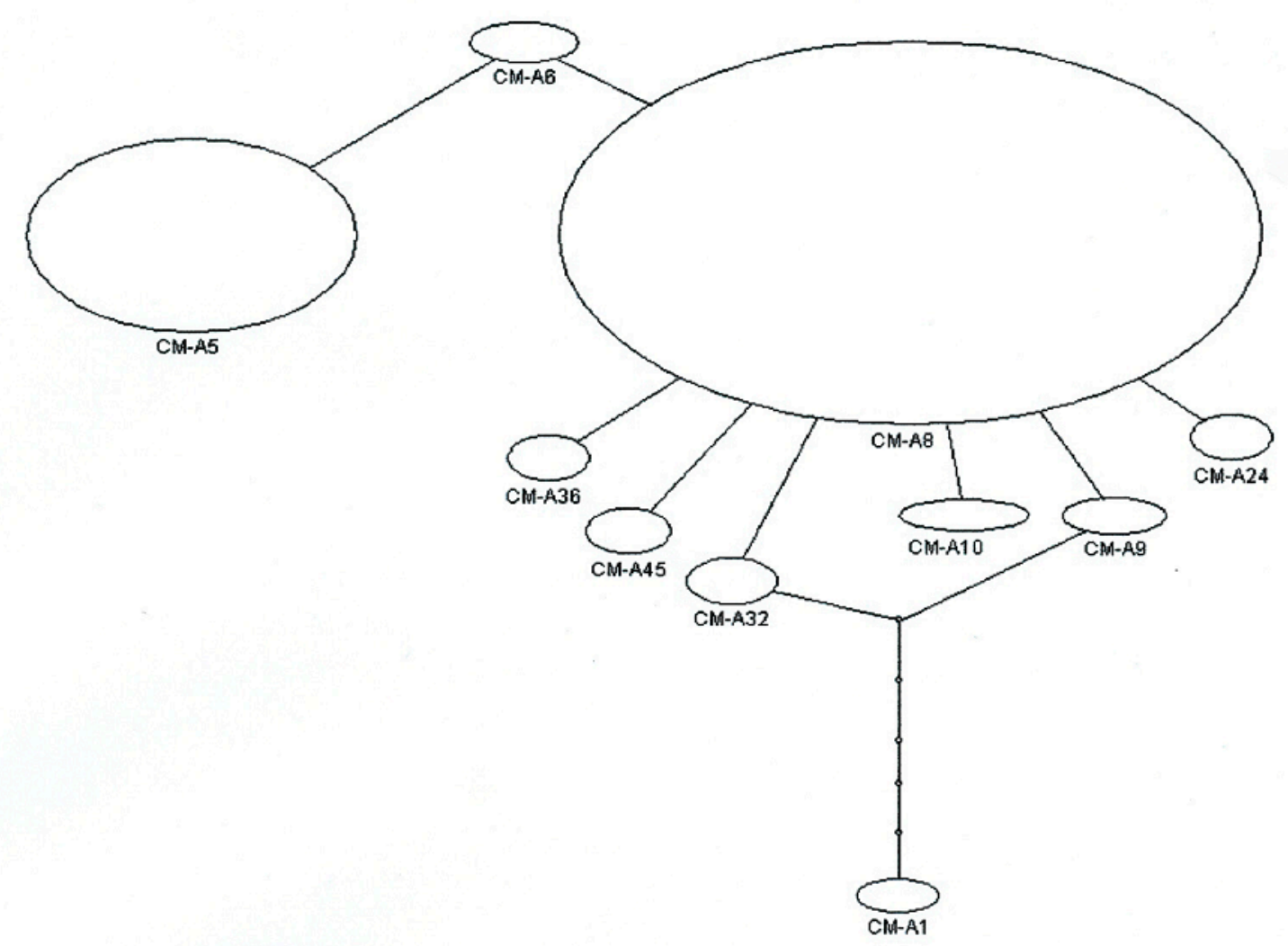

Figura 10. Rede haplotipica construída a partir da amostra obtida na região de estudo. Cada oval representa um haplótipo e o tamanho que estas figuras apresentam é proporcional a frequência apresentada por cada haplótipo. Cada linha que conecta as figuras, assim como os pontos contidos nestas representam substituições de uma base nucleotídica- 
O teste exato de diferenciação global realizado entre as amostras coletadas nos anos de 2005, 2006, 2007 e 2008 revelou diferença significativa entre estes ( $p=$ $0,02732 \pm 0,00628$ ) apesar de o teste do $X^{2}$ não rejeitar a homogeneidade entre os mesmos $\left(\mathrm{X}^{2}=36,17 ; \mathrm{gl}=27 ; p=0,06\right)$. Ao analisar cada ano de coleta separadamente, observaram-se diferenças na composição haplotípica apenas entre os anos de 2005 e $2006(p=0,04582 \pm 0,0082)$ e entre 2006 e 2008 ( $p=0,01684 \pm 0,0019)$, e este resultado foi confirmado através do teste do $\mathrm{X}^{2}$.

Em relação às estações analisadas, o teste de diferenciação global não aponta variação em suas composições genéticas ( $p=0,12276 \pm 0,02258$ ), porém, ao analisar cada estação de coleta, verificaram-se diferenças significativas entre a $2^{\circ}$ estação de verão e a $3^{\circ}$ estação de inverno ( $\left.p=0,02989 \pm 0,0047\right)$ e, entre a $2^{\circ}$ e a $3^{\circ}$ estações de verão ( $p=0,04226 \pm 0,0033)$. O teste do $\mathrm{X}^{2}$ confirmou estes resultados indicando homogeneidade entre todas as estações $\left(\mathrm{X}^{2}=57,87 ; \mathrm{gl}=54 ; p=0,35\right)$ e para a $2^{\circ}$ e $3^{\circ}$ estações de verão $\left(\mathrm{X}^{2}=8,56 ; \mathrm{gl}=4 ; p=0,094\right)$. Entretanto, para a $2^{\circ}$ estação de verão e a $3^{\circ}$ estação de inverno, o teste do $\mathrm{X}^{2}$ rejeita a homogeneidade confirmando o resultado obtido através do teste exato de diferenciação.

Para a caracterização de Cananéia como sítio de alimentação, testes de homogeneidade, conduzidos através do programa CHIRXC rejeitaram esta hipótese, tanto em relação às outras áreas de alimentação do Oceano Atlântico, $\left(X^{2}=174\right.$; gl = $290 p=0,000)$ como em relação aos sítios de alimentação mais próximos: Almofala, Ubatuba, Atol das Rocas/Fernando de Noronha e Uruguai $\left(X^{2}=213,64\right.$; gl = 90; $p=$ 0,000) . A comparação par-a-par entre as populações indica que todas estas são significativamente distintas, com exceção de Atol das Rocas/Fernando de Noronha ( $p=$ 0,188; Tabela 02). 
Tabela 02. Comparação par a par entre as áreas de alimentação descritas na literatura e Canenéia. A) valores de $\mathrm{X}^{2}$. B) valores de $F$ st e C) valores de $\Phi$ st. A significância do valor de $p<0.05$ é indicada como *, $p<0.001$ como ** e $p<0.0001$ como *w*

\begin{tabular}{|c|c|c|c|c|c|c|c|c|c|c|c|}
\hline$x^{2}$ & C. Norte & Flórida & Bahamas & Barbados & Nicaragua & Almofala & $\begin{array}{l}\text { A. } \\
\text { Rocas/Noronha }\end{array}$ & Ubatuba & Uruguai & Corisco & G. Guiné \\
\hline Cananéia & $258,51^{* * *}$ & $259.05^{\star \star \star}$ & $247,12^{\star \star \star}$ & $123,62^{* \star *}$ & $246,84^{\star \star \star *}$ & $51,22^{\star \star \star \star}$ & 19,89 & $27,26^{*}$ & $23,12^{\star}$ & $61,52^{\star * *}$ & $62,72^{\star \star \star \star}$ \\
\hline Fst & C. Norte & Flórida & Bahamas & Barbados & Nicaragua & Almofala & $\begin{array}{l}\text { A. } \\
\text { Rocas/Noronha }\end{array}$ & Ubatuba & Uruguai & Corisco & G. Guiné \\
\hline Cananéia & $0.34125^{\star * *}$ & $0.47322^{\star \star \star}$ & $0.50438^{\star \star \star}$ & $0.19330^{\star \star \star}$ & $0.56845^{\star \star \star *}$ & $0.03819^{\star \star \star}$ & -0.01128 & $0.02440^{\star \star \star}$ & $0.04647^{\star \star \star}$ & $0.05543^{\star \star \star}$ & $0.06477^{\star \star \star \star \star}$ \\
\hline Фst & C. Norte & Flórida & Bahamas & Barbados & Nicaragua & Almofala & $\begin{array}{l}\text { A. } \\
\text { Rocas/Noronha }\end{array}$ & Ubatuba & Uruguai & Corisco & G. Guiné \\
\hline Cananéia & $0.78429^{\star \star \star}$ & $0.85676^{* * *}$ & $0.77727^{\star \star \star}$ & $0.48981^{\text {t*k}}$ & $0.84322^{* \star *}$ & $0.09161^{\star \star \star \star}$ & -0.01696 & $0.03678^{\star \star \star *}$ & $0.06156^{* \pm *}$ & $0.06013^{\star \star \star \star}$ & $0.08505^{* * *}$ \\
\hline
\end{tabular}


Análise da variância molecular (AMOVA) calculada para todos os sítios de alimentação do Oceano Atlântico indica que a maior parte da variabilidade está entre as populações analisadas. Este resultado foi confirmado através do teste do X2 que rejeitou a hipótese de homogeneidade entre tais áreas (X2=1808,56; $\mathrm{gl}=372 ; \mathrm{p}=0,0009$ ). Entretanto, ao analisar os sítios de alimentação mais proximamente localizados à área de estudo (Almofala, Atol das Rocas/Fernando de Noronha, Ubatuba e Uruguai), observou-se que 94-96\% da variabilidade é encontrada dentro das populações e aproximadamente 6-4\% da variação está entre estas populações o que indica que a maior parte da variabilidade pode ser atribuída a diferença individual. Ainda que, relativamente pequenas, o resultado do teste do X2 confirma esta diferenciação visto que rejeita a homogeneidade entre estas (X2=146,93; gl=68; $\mathrm{p}=0,0009)$.

Tabela 03. AMOVA entre áreas de alimentação do Oceano Atlântico (Tabela 01) baseada em dois métodos. A. Utilizando a matriz de distância calculada a patir do modelo Kimura 2-parâmetros (Kimura, 1980). B. Utilizando a estatística $F$ convencional, calculada a partir das frequências haplotípicas.

\begin{tabular}{lcc} 
AMOVA & $\begin{array}{c}\text { \% de variação } \\
\text { A. Distância Genética }\end{array}$ & $\begin{array}{l}\text { B. Frequências } \\
\text { Haplotípicas }\end{array}$ \\
\hline $\begin{array}{l}\text { Entre } \\
\text { populações }\end{array}$ & $58,14 \%$ & $28,47 \%$ \\
$\begin{array}{l}\text { Dentro de } \\
\text { Populações }\end{array}$ & $41,86 \%$ & $71,53 \%$ \\
\hline Fst & $0,5814 \quad(p=0,00)$ & $0,2846(p=0,00)$
\end{tabular}

Tabela 04. AMOVA entre áreas de alimentação do Atlântico Sul Ocidental (Tabela 01) baseada em dois métodos. A. Utilizando a matriz de distância calculada a patir do modelo Kimura 2-parâmetros (Kimura, 1980). B. Utilizando a estatística $F$ convencional, calculada a partir das frequências haplotípicas.

\begin{tabular}{lcc} 
AMOVA & $\begin{array}{c}\text { \% de variação } \\
\text { A. Distância Genética }\end{array}$ & $\begin{array}{l}\text { B. Frequências } \\
\text { Haplotípicas }\end{array}$ \\
\hline $\begin{array}{l}\text { Entre } \\
\text { populações }\end{array}$ & $6,40 \%$ & $4,41 \%$ \\
$\begin{array}{l}\text { Dentro de } \\
\text { Populações }\end{array}$ & $93,60 \%$ & $95,59 \%$ \\
\hline Fst & $0,06 \quad(p=0,000)$ & $0,04(p=0,000)$
\end{tabular}

\subsection{Discussão}




\subsubsection{Dados Populacionais}

A população amostrada em Cananéia é composta por juvenis, que visitam esta localidade ao longo do ano, o que confirma que a região é uma área de alimentação para esses animais durante nesta etapa de seu ciclo de vida (Bondioli, 2008). Animais de comprimento curvilíneo da carapaça superior a $50 \mathrm{~cm}$ foram raramente registrados, sendo amostrados apenas 5 indivíduos nesta fase (2\%) durante os quatro anos de atividades de coleta, todos encontrados mortos nas praias da região. Por integrar um corredor migratório para esta espécie (Caraccio, 2008), é provável que estes animais tenham sido mortos em locais próximos a região de estudo, em zonas mais profundas, enquanto realizavam movimentos migratórios, visto que animais deste tamanho não são observados com frequência, próximos à costa. Por este motivo, tais indivíduos foram excluídos das análises populacionais descritas neste trabalho. Onze indivíduos acometidos por fibropapilomas foram amostrados (5\%), e em alguns casos recapturados, o que possibilitou o acompanhamento da evolução dessa doença (Bondioli, 2007). No entanto, por se tratar de um número bastante reduzido, testes comparativos entre indivíduos saudáveis e doentes não puderam ser realizados.

Para aqueles indivíduos recapturados, o intervalo de tempo existente entre as capturas indicou que estes animais utilizam a região por períodos que podem exceder 17 meses, confirmando sua utilização para desenvolvimento, por juvenis de tartarugas verdes. Além de apresentar grande abundância de seu alimento de preferência (algas marinhas), a região estuarina de Cananéia é constituída por águas rasas e abrigadas, o que confere proteção a outras espécies que se utilizam da área como berçário e abrigo, como é o caso do boto-cinza Sotalia guianensis (Monteiro-Filho, 2000). Da mesma forma e, pela inexistência de grandes predadores, a região pode servir de abrigo para as tartarugas verdes durante sua fase juvenil, visto que nesta fase ainda são bastante vulneráveis a tubarões e outros peixes de grande porte (Musick e Limpus, 1997).

\subsubsection{Diversidade genética em Cananéia}

A simplicidade da rede haplotípica representada permitiu acessar o relacionamento genético entre os haplótipos baseando-se no critério da parcimônia ou 
na diferença entre as frequências haplotípicas. A grande frequência observada para CM08 se deve ao fato de se tratar do haplótipo predominante nas colônias do Atlântico e mais disseminado nas praias equatoriais (Encalada, 1996), sendo registrado como o mais frequente em áreas de desova localizadas na Guiné Bissau, Bioko, São Tomé e Príncipe, Ilhas Ascensão, Atol das Rocas, Fernando de Noronha e Trindade (Formia, 2006; Bjorndal 2006). Por este motivo, e devido a sua posição central na rede haplotípica, CM-08 foi descrito como o mais próximo ao haplótipo ancestral que colonizou o Oceano Atlântico (Encalada, 1996; Formia, 2002). Áreas de alimentação do Oceano Atlântico apresentam esse haplótipo como Carolina do Norte, Barbados e Bahamas e o mesmo perfil de predominância encontrado neste estudo foi descrito para sítios de forrageio localizados no Atlântico Sul Ocidental, como Almofala, Ubatuba, Fernando de Noronha e Uruguai além daqueles localizados na Costa Africana, como Corisco e Golfo da Guiné (Formia, 2002; Naro-Maciel, 2007; Caraccio, 2008).

O haplótipo CM-05 foi o segundo mais frequentemente registrado (26\%), sendo descrito para áreas de desova do México, Venezuela, Suriname e São Tomé (Encalada, 2006; Formia, 2006). Este haplótipo foi igualmente registrado em áreas de alimentação do Atlântico Norte e Sul, porém as frequências registradas nesta área de estudo são bastante superiores à maioria dos registros, sendo comparável apenas com Almofala (24\%), descrita como uma das mais diversas em termos genéticos, em relação aos outros sítios de forrageio do Atlântico. Almofala recebe animais provenientes dos maiores estoques de ambos os hemisférios devido à sua localização estratégica e, portanto, incluem as duas linhagens de haplótipos da base Atlântica (Encalada, 1996). Evidências provenientes de estudos de marcação e recaptura confirmam esta hipótese descrevendo Almofala como área de alimentação para adultos e juvenis provenientes de Suriname e Venezuela (Meylan, 1995) assim como de outras áreas de desova localizadas no Atlântico Sul Ocidental (Luschi, 1998).

O haplótipo CM-06 foi registrado em baixa frequência (3,2\%) e este foi descrito para áreas de desova localizadas em Ascensão, Bioko, São Tomé e Suriname e registrado anteriormente em áreas de alimentação do Atlântico Sul Ocidental como Almofala, Atol das Rocas e Uruguai (Naro-Maciel, 2007; Bjorndal, 2006; Caraccio, 2009).

A presença dos haplótipos CM-09 (2,7\%), CM-10 (1,3\%), CM-24 (0,45\%) e CM-32 (1,3\%) em baixas frequências é característica para áreas de alimentação e todos estes 
são provenientes de áreas de desova localizadas no Atlântico Sul confirmando existir em Cananéia, o padrão típico para áreas de forrageio.

O registro do haplótipo CM-36, tipicamente descrito para praias de desova de São Tomé e Príncipe, indica claramente que Cananéia recebe tartarugas provenientes de colônias africanas e sua importância como provedora de recursos energéticos para os animais que se originam nesta região.

A ocorrência de CM-45 é bastante rara e tal haplótipo foi descrito apenas para as Ilhas Ascensão, tendo como único registro no sítio de forrageio de Almofala (CE) (Naro-Maciel, 2007). Tal registro apenas confirma a contribuição da segunda maior colônia do Atlântico (Broderick, 2006) para esta área de forrageio visto que esta é primariamente composta pelo haplótipo CM-08 (83\%) e compartilha ainda outros cinco haplótipos com a região de estudo. Ascensão recebe cerca de 3700 fêmeas anualmente para nidificação e está sob a influência direta da Corrente do Brasil e Sul Equatorial, que provavelmente são responsáveis pelo deslocamento de grande parte dos filhotes provenientes desta área, e uma vez que estes alterem seu hábito alimentar para a herbivoria, passam a utilizar regiões de forrageio da costa brasileira.

Por fim, o haplótipo CM-1, descrito como proveniente do México e Flórida, é comumente encontrado em áreas de alimentação do Atlântico Norte, sendo registrado no Atlântico Sul apenas no Uruguai (Caraccio, 2008). Isto pode ocorrer devido a incompleta caracterização das áreas de desova localizadas no Oceano Atlântico, porém pode indicar que Cananéia também recebe contribuições de estoques pertencentes a linhagem distinta daquela que compõe o grupo do Atlântico Sul Ocidental, ainda que em frequências menores.

Estes dados confirmariam a hipótese inicial, segundo a qual, Cananéia receberia indivíduos provenientes de diferentes linhagens (lhas Ascensão, Caribe Oriental, Costa Ocidental da Africa e colônias brasileiras Atol das Rocas, Trindade e Fernando de Noronha) e ampliam tal hipótese, ao detectar a presença de animais pertencentes a um grupo filogeográfico distinto do qual acreditariamos fazer parte todos os animais registrados neste trabalho (CM-01), evidenciando a importância da região para a manutenção das populações de tartarugas verdes, em escala regional, como também para a base Oceânica Atlântica.

Cananéia apresentou valores intermediários de diversidade haplotípica e nucleotídica em relação aos outros sítios de alimentação de tartarugas verdes do Atlântico (Tabela 05). 


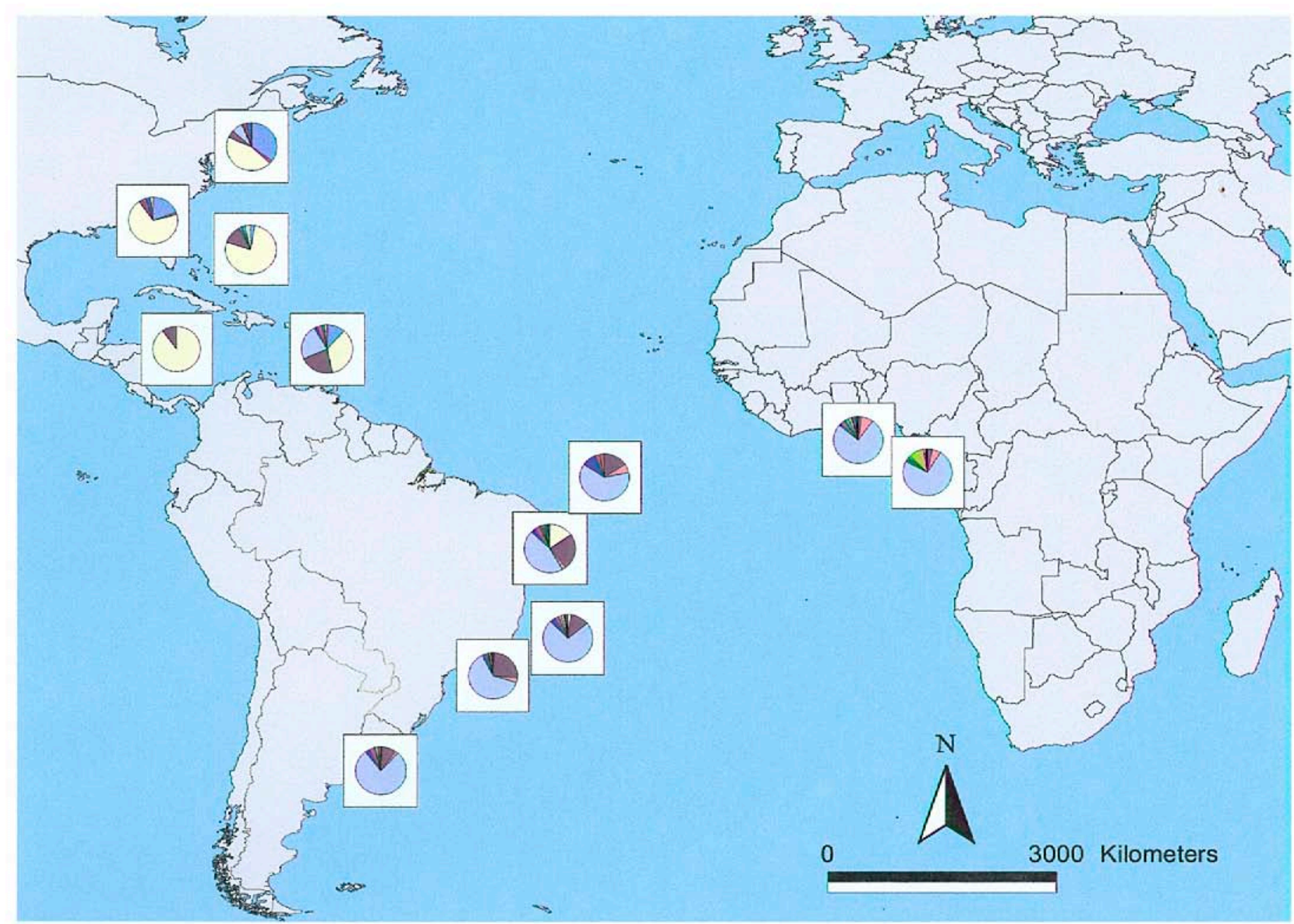

Figura 11. Mapa da distribuição haplotipica entre as áreas de alimentação analisadas neste estudo (Tabela 01). 
Tabela 05. Áreas de alimentação do Atlântico, tamanho amostral, número de haplótipos e índices de diversidade haplotípica e nucleotídica, e seus respectivos valores de desvio padrão. (Bass, 2006; Bass e Witzel, 2000; Formia, 2002, Lahanas, 1998; Luke, 2004; Bass, 1998; Naro-Maciel, 2007 e Caraccio, 2008).

\begin{tabular}{|c|c|c|c|c|c|}
\hline Áreas de Alimentação & $\mathbf{N}$ & $\mathrm{N}^{\circ}$ de Haplótipos & Div Haplotípica & \multicolumn{2}{|c|}{ Div Nucleotídica } \\
\hline Carolina do Norte & 106 & 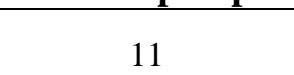 & $0,7290+/-0,0300$ & $0,005274+/-$ & 0,003166 \\
\hline Florida & 62 & 6 & $0,4855+/-0,0668$ & $0,003097+/-$ & 0,002102 \\
\hline Golfo da Guiné & 395 & 11 & $0,4437+/-0,0479$ & $0,001987+/-$ & 0,001511 \\
\hline Corisco & 239 & 13 & $0,4415+/-0,0400$ & $0,001600+/-$ & 0,001301 \\
\hline Bahamas & 79 & 6 & $0,3703+/-0,0650$ & $0,006146+/-$ & 0,003603 \\
\hline Barbados & 60 & 8 & $0,7734+/-0,0276$ & $0,010274+/-$ & 0,005624 \\
\hline Nicaragua & 60 & 2 & $0,1831+/-0,0621$ & $0,003806+/-$ & 0,002461 \\
\hline Almofala & 117 & 13 & 0,7168+/- 0,0306 & $0,007607+/-$ & 0,004295 \\
\hline Atol/F Noronha & 23 & 5 & $0,6443+/-0,0917$ & $0,002186+/-$ & 0,001678 \\
\hline Ubatuba & 113 & 10 & $0,4460+/-0,0556$ & $0,002047+/-$ & 0,001547 \\
\hline Cananéia & 219 & 10 & 0,5393 +/- 0,0300 & $0,002138+/-$ & 0,001588 \\
\hline Uruguai & 144 & 10 & $0,3867+/-0,0506$ & $0,001411+/-$ & 0,001200 \\
\hline
\end{tabular}

Em relação às diversidades haplotípicas encontradas em outras áreas de alimentação, esta região apresentou um número de haplótipos bastante significante ao passo que o valor encontrado para a diversidade nucleotídica é bastante baixo e isto se deve ao fato de haver poucas diferenças nucleotídicas entre estes. Os haplótipos registrados apresentam, em sua maioria apenas um sítio polimórfico em relação ao CM08, com exceção de CM-01 que por pertencer a outra linhagem apresenta sete diferenças nucleotídicas.

A diversidade observada nesta área de forrageio apresentou valores intermediários àqueles encontrados em Almofala (CE) e Ubatuba (SP) e, apesar da proximidade deste último sítio $(350 \mathrm{~km})$, apresenta maior diversidade haplotípica e nucleotídica que este e maior número de haplótipos compartilhados com Almofala.

\subsubsection{Análise Temporal}


As análises temporais indicaram haver variação entre os anos e, apesar de não haver diferenças temporais na maioria dos estudos realizados em áreas de alimentação, estes trabalhos não amostraram períodos superiores a um ano com apenas cinco exceções: Bass (2004), que analisou uma população de $C$. caretta durante três anos, Naro-Maciel (2007) que amostrou duas populações de C. mydas da costa brasileira, durante dois anos, Caraccio (2008) que amostrou C. mydas na costa uruguaia, durante dois anos, Velez-Zuazo (2008) que realizou um estudo de cinco anos com E. imbricata e Bjorndal (2008) cuja análise temporal foi conduzida durante um período de 10 anos para a população de juvenis que frequenta a região sul de Bahamas. Com exceção deste último, nenhum destes estudos apresentaram alterações significativas nas frequências haplotipicas ao longo do tempo e, seus autores observam que esta ausência de variação pode ser atribuída ao curto intervalo de tempo amostrado (dois anos, Naro-Maciel, 2007) ou ao tamanho amostral reduzido (8-18 tartarugas por ano, Vezez-Zuazo, 2008). Bjorndal (2008) encontraram uma estruturação temporal significativa e a atribuem à substancial variação nas contribuições relativas às diferentes colônias, entre anos, de acordo com os resultados obtidos através da análise bayesiana.

No presente trabalho a variação na composição haplotípica global e entre os anos de 2005 e 2006 e entre 2006 e 2008, podem refletir uma variação substancial na contribuição de diferentes colônias entre anos (Bjorndal, 2008), estar relacionadas aos ciclos migratórios exibidos por esses animais ou ser apenas reflexo da diferença entre amostragens. Os ciclos reprodutivos de tartarugas verdes em geral são de 2 ou 3 anos e o padrão utilizado pelos juvenis, ao migrarem entre as áreas de forrageio ainda permanece desconhecido. Estudos realizados a longo prazo, encontraram diferenças entre anos consecutivos e, ao se tratar de animais que não exibem ciclos anuais como é o caso das tartarugas verdes, amostragens de pelo menos dois anos são recomendadas a fim de descrever adequadamente a diversidade haplotípica da região estudada (Formia, 2007). Tais resultados confirmam a necessidade de estudos populacionais a longo prazo a fim de avaliar o nível de variação entre anos e se este padrão se confirma para períodos de tempos mais longos.

Em relação às análises sazonais, não foi registrada diferença genética global entre os grupos amostrados no verão e inverno embora os resultados das comparações entre algumas estações sejam discordantes. Assim como para outros vertebrados 
marinhos, a distribuição dos haplótipos da região controle do DNA mitocondrial das tartarugas verdes no Oceano Atlântico, tem sido caracterizada por poucos haplótipos comuns e muitos haplótipos raros (Lahanas, 1994; Encalada, 1996; Formia, 2006). Nestes casos, erros amostrais podem tornar as análises tendenciosas e pequenas amostras diminuem sua resolução, reduzindo seu poder em discriminar populações e detectar haplótipos raros ou únicos (Formia, 2007). Cabe ressaltar que, devido a problemas na obtenção de anilhas, houve a interrupção de coleta e a amostragem foi bastante prejudicada, principalmente durante a $1^{\circ}$ estação de verão e a $2^{\circ}$ estação de inverno, o que pode ter influenciado sensivelmente os dados obtidos, impossibilitando algumas conclusões.

\subsubsection{Diferenciação Genética - Áreas de alimentação do Atlântico}

É interessante observar que, apesar da proximidade e das diferenças identificadas geneticamente, desde o início das coletas e, portanto, da marcação dos animais na região de Cananéia, nenhum individuo foi recapturado em Ubatuba. Da mesma forma, Cananéia não apresenta nenhum registro de recaptura de animais marcados em Ubatuba, apesar de haver registro de animais do Rio de Janeiro (1), Caraguatatuba (1), Balneário da Penha (1) e Uruguai (3) (Dados não publicados).

Outros trabalhos indicam também diferenças entre as duas regiões como, por exemplo, na diversidade e quantidade de parasitas internos registrados nestas duas regiões (Loreto, Dados não publicados). Conforme sabemos, a fauna associada às tartarugas marinhas pode ser utilizada de forma indireta para acessar a origem destes animais e para inferir possíveis rotas migratórias (Lutcavage, 1997). Segundo o presente trabalho, pode-se dizer que Ubatuba e Cananéia, apesar de compartilhar haplótipos são estoques mistos distintos. Estudos que comprovem esta diferenciação devem ser conduzidos a fim de esclarecer a relação entre tais regiões.

A hipótese de homogeneidade entre Cananéia e as outras áreas de alimentação localizadas no Oceano Atlântico foi rejeitada, confirmando assim a existência de um estoque misto nesta área, cujas análises estão descritas no próximo capítulo do presente trabalho.

Atol das Rocas/Fernando de Noronha não foram significativamente diferentes de Cananéia e este resultado pode estar relacionado ao tamanho amostral reduzido 
apresentado para esta área (23 amostras). Formia (2007) ao analisar as praias de desova localizadas em Ascensão mostra claramente a importância de tamanhos amostrais adequados para a obtenção de resultados significativos, ao comparar valores de Fst em diferentes tamanhos amostrais e encontrar diferenças bastante relevantes entre eles. Tais valores, inicialmente avaliados como não significativos, mostraram-se claramente distintos em sua reavaliação e, uma consequência bastante importante desta diferença é a recomendação de que tais regiões devem ser manejadas como unidades distintas (Formia, 2007).

Em relação a comparação entre os índices calculados para a distinção entre as populações, embora exista um debate sobre qual índice (Fst ou $\Phi$ st) apresenta resultados mais realísticos, O’Corry-Crowe (1997) sugere que Fst produz estimativas mais acuradas, quando analisamos amostras em que os haplótipos se distinguem por um número pequeno de substituições e quando as populações são distinguíveis baseado nas diferenças das frequências haplótípicas, como é o caso do presente estudo.

Os resultados da AMOVA indicam que maior parte da variabilidade está entre as áreas de alimentação, porém uma quantidade significativa é encontrada dentro destas. Entretanto, ao analisar as áreas de alimentação mais próximas à área de estudo, observamos claramente que a variabilidade está quase totalmente dentro destas, restando menos de $10 \%$ de diferença entre estas. Isto é esperado devido à proximidade dos sítios e uniformidade exibida entre eles, contudo a comparação par a par entre tais populações indica que todas elas são significativamente distintas entre si. 


\section{Capítulo 3}

3.1Análise dos Estoques Populacionais: A relação entre áreas de alimentação e desova do Atlântico Sul Ocidental

\subsubsection{Introdução}

A tartaruga verde (Chelonia mydas) é uma espécie altamente migratória, que realiza extensas viagens transoceânicas, ao longo de seu ciclo de vida. Pesquisadores sugerem que este comportamento esteja relacionado com seu hábito herbívoro (Hendrickson, 1980). Isto porque raramente existem bancos de algas ou pasto marinho de boa qualidade e em abundância, proximamente localizados as praias de desova e vice-versa; fontes adequadas de alimento não são encontradas próximas a ilhas remotas, que usualmente são utilizadas como áreas de desova. Entretanto, mesmo quando estes sítios localizam-se proximamente, ciclos migratórios de milhares de kilômetros ainda persistem, o que significa que uma fêmea não necessariamente se alimenta em áreas próximas à praia de desova, tampouco que desove em locais próximos aos seus sítios de forrageio (Limpus, 1992).

Evidências provenientes de estudos de marcação e recaptura e telemetria têm auxiliado a descrição deste comportamento mostrando que um determinado estoque se dispersa entre diferentes sítios de forrageio. Embora machos e fêmeas exibam comportamento filopátrico (Karl, 1992; Robert, 2004), raramente existem registros de recaptura em áreas de alimentação (Lima, 1999). Dados obtidos através de transmissores satelitais indicam que as tartarugas verdes são capazes de percorrer uma reta quase perfeita, cruzando o mar aberto, em direção aos seus destinos, durante seu ciclo migratório (Luschi, 1998) utilizando como mecanismo de orientação o geomagnetismo (Luschi, 2007), a direção dos ventos e a percepção olfativa de determinados fatores químicos (Hays, 2003).

\subsubsection{A contribuição dos dados moleculares}

Análises genéticas podem ser utilizadas para inferir padrões migratórios e composição demográfica de populações mistas. O estudo de tais populações permite 
entender a diferença genética existente entre estas, possibilitando assim a definição de unidades que as constituem, conhecidas como estoques (Chapman, 1996). O estudo destas unidades é conhecido como Análise de Estoque Misto (do inglês Mix Stock Analysis, MSA) e representa uma fonte de valiosas descobertas que possibilitam seu manejo e manutenção adequados (Formia, 2002).

Inicialmente os programas que conduziam MSA utilizavam algoritmos baseados no critério da máxima verossimilhança (do inglês Maximum Likelihood, ML) e populações de tartarugas marinhas em áreas de alimentação foram analisadas através deste método. Bowen (1996) utilizou MSA para acessar uma população de juvenis de tartarugas de pente, amostradas no Caribe a fim de determinar quais áreas de desova poderiam ser impactadas pela mortalidade causada por fatores antrópicos nesta área. Lahanas et al (1998) estudaram uma área de alimentação de juvenis de tartarugas verdes, localizada em Great Inaguá, Bahamas com o intuito de quantificar as contribuições e avaliar a importância que cada estoque representa para a manutenção desta área de forrageio. Outros estudos realizados através deste método mostram-se úteis no entendimento do comportamento migratório e no impacto causado pelas correntes oceânicas no modo de dispersão apresentado por juvenis (Bowen, 1995; Bass, 2004; Bass, 2006).

Recentemente a estatística Bayesiana tem sido incorporada à MSA (Pella e Masuda, 2001), produzindo resultados que levam em conta erros de amostragem (Bolker, 2003). Este método baseia-se na distribuição de probabilidades a partir das estimativas de composição de cada estoque, tornando-se bastante adequado para a análise de populações de tamanho pequeno, que possuem haplótipos raros (Formia, 2002).

MSA bayesiana tem sido amplamente aplicada a estudos populacionais das diferentes espécies de tartarugas marinhas. No Oceano Atlântico, trabalhos foram realizados a fim de acessar as áreas de alimentação de tartarugas verdes (Bass, 2000; Formia, 2002; Luke, 2004; Bass, 2006; Naro-Maciel, 2007) de tartarugas cabeçudas (Bass, 2004; Carreras, 2006; Reece, 2006), assim como de tartarugas de pente ( Bowen, 2007; Velez-Zuazo, 2008).

O conhecimento do status populacional em áreas de alimentação é crucial para a manutenção e recuperação de populações ameaçadas. Estas regiões recebem juvenis e subadultos, que após atingirem a maturidade sexual irão compor a população reprodutiva. Informações sobre a origem dos juvenis que compõem um estoque misto 
são valiosas e complementam dados obtidos em outras etapas do ciclo de vida destes animais constituindo um importante arcabouço para planos de manejo eficazes.

\subsubsection{A conectividade entre áreas de alimentação}

A relação entre agrupamentos de tartarugas marinhas, que ocupam habitats distintos é ainda hoje insuficientemente compreendida, e seu entendimento é essencial tanto para esclarecer aspectos biológicos de seu ciclo de vida quanto para propósitos conservacionistas, sendo igualmente relevantes para a compreensão de outras espécies de tartarugas e outros organismos marinhos (Naro-Maciel, 2006). O esclarecimento da ligação entre populações de tartarugas marinhas permite buscar compreender o funcionamento de sua navegação durante os movimentos migratórios, avaliar seu papel no ecossistema marinho e costeiro, e investigar qual o impacto causado por ações antropogênicas sobre estes animais. Além disto, permite analisar perdas de diversidade genética entre estes agrupamentos e seus potenciais efeitos evolutivos, a curto e longo prazo. A quantificação desta ligação entre diferentes habitats de alimentação e desova é essencial para proteger espécies migratórias ao longo de toda sua área de distribuição (Martin, 2007).

Estudos têm sido realizados sobre a sub-estrutura encontrada dentro de populações de tartarugas marinhas (Bass, 2006; Naro-Maciel, 2007; Velez-Zuazo, 2008). A avaliação dos padrões de conectividade, em escala regional permite o aumento da resolução da conectividade em larga escala geográfica, esclarecendo processos importantes como o recrutamento de juvenis a partir do ambiente pelágico, para as zonas neríticas de alimentação (Bass, 1999). Para avaliar a conectividade entre espécies migratórias baseando-se em marcadores genéticos, o entendimento da variação temporal é essencial. Muitas populações de tartarugas marinhas utilizam-se de áreas de alimentação sobrepostas, tanto durante sua fase oceânica como nerítica. O manejo efetivo de espécies migratórias, principalmente aquelas de grande valor econômico, como o bacalhau (Ruzzante, 2000) e o salmão (Waples, 1990), requer o conhecimento de seus padrões de movimento e distribuição, temporais e espaciais. O mesmo pode ser aplicado à conservação de baleias e tartarugas marinhas (Baker, 2000; Bowen, 2007).

Recentemente um novo método para análise da relação existente entre áreas de desova e estoques mistos foi desenvolvido por Ben Bolker (2007) denominado "Many- 
to-Many”. Ao realizar qualquer MSA, o pesquisador gera estimativas de contribuição de todos os potenciais estoques em relação a uma área de alimentação, o que Bolker designa como análise "Many-to-One”. Many-to-Many gera simultaneamente estimativas de origem e destino de indivíduos da metapopulação formada por múltiplas áreas de desova e múltiplas áreas de alimentação. Este método fornece informações que contribuem para o entendimento da ecologia espacial e conectividade entre populações de espécies migratórias, como as tartarugas marinhas.

No presente trabalho analisamos uma área de alimentação localizada em Cananéia que recebe a visita de juvenis de tartarugas verdes e sua conectividade com outras áreas de alimentação localizadas no Oceano Atlântico, com base em sequências da região controle do DNA mitocondrial.

\subsection{Objetivos}

Este trabalho tem por objetivo avaliar a contribuição de cada área de desova, de modo a conhecer a importância da região de Cananéia para os diferentes estoques contribuintes, com base nos padrões de frequências haplotípicas buscando:

- Quantificar a contribuição de cada estoque populacional, analisando sua importância em relação a estes;

- Avaliar os diferentes métodos de análises, em relação ao seu poder de resolução na produção de resultados mais próximos da realidade biológica desta espécie;

- Entender a conectividade e interligação entre as diferentes áreas de desova e de alimentação, em escala regional e no Oceano Atlântico.

\subsection{Metodologia}

Amostras de 219 sequências gênicas correspondentes ao tRNA-Pro+D-loop do DNA mitocondrial de Chelonia mydas, da região de Cananéia, obtidas durante os quatro anos de coleta foram analisadas em conjunto com dados existentes na literatura para onze áreas de desova que potencialmente poderiam contribuir para esta área de alimentação (Tabela 06). São Tomé e Príncipe são consideradas como uma única área 
de desova por não apresentar diferenças significativas em suas composições haplotípicas, em estudos anteriormente realizados (Formia, 2006).

Tabela 06. Áreas de desova utilizadas neste estudo, números amostrais, número aproximado de fêmeas anidadoras por estação reprodutiva, a distância existente entre estas áreas e Cananéia e referências utilizadas.

\begin{tabular}{ccccc} 
Área de desova & $\mathbf{N}^{\mathbf{o}}$ & $\mathbf{N}^{\mathbf{0}}$ de fêmeas & Distância (km) & Referência \\
\hline \hline Flórida & 24 & 783 & 6772 & Seminoff, 2004 \\
Costa Rica & 433 & 27023 & 5524 & Seminoff, 2004 \\
Ilhas Aves & 30 & 267 & 4834 & Seminoff, 2004 \\
México & 20 & 1593 & 6577 & Seminoff, 2004 \\
A. Rocas & 69 & 115 & 2802 & Bellini, 1995 \\
I. Trindade & 99 & 3000 & 1966 & Seminoff, 2002 \\
Ilhas Ascensão & 187 & 4000 & 4026 & Formia, 2002 \\
Bioko & 50 & 500 & 6868 & Formia, 2002 \\
Guiné Bissau & 51 & 2526 & 5390 & Catry, 2002 \\
São Tomé/Príncipe & 26 & 180 & 6506 & Formia, 2006 \\
Suriname & 15 & 1815 & 3543 & Seminoff, 2004
\end{tabular}

\subsubsection{Testando a hipótese de "estoque misto"}

Inicialmente, foram realizados testes exatos de diferenciação, comparações através dos valores de Fst e Фst, para cada praia de desova e teste do $\mathrm{X}^{2}$ a fim de testar a homogeneidade entre estas áreas e o estoque misto presente em Cananéia e comparar os referidos índices.

O teste exato de diferenciação e comparações através de valores de Fst e Фst para cada área foram calculados através do programa Arlequin 3.01(Excoffier, 2005). O teste do $\mathrm{X}^{2}$ foi realizado através do programa CHIRXC (Zaykin e Pudovkin, 1993).

\subsubsection{Análise de Estoque Misto: Máxima Verossimilhança}

Dois métodos foram utilizados para estimar a contribuição relativa de cada área de desova para o estoque misto em questão: máxima verossimilhança (ML) e análise bayesiana (B). Tais estimativas foram conduzidas a fim de comparar os métodos e a 
robustez de seus resultados, visto que estes produziram informações discordantes em trabalhos anteriores (Bass, 2004). Haplótipos descritos apenas em áreas de alimentação foram necessariamente excluídos destas análises, no entanto, por se tratar de haplótipos raros acredita-se não provocar impacto nas análises (Naro-Maciel, 2005).

Para as análises de máxima verossimilhança (ML) foi utilizado o programa de estatística R 2.9.0 (The R Foundation for Statistical Computing, 2009) e, intervalos de confiança referentes às estimativas obtidas para cada área de desova foram obtidos através do emprego do mesmo programa.

\subsubsection{Análise Bayesiana: Many-to-One}

A MSA bayesiana foi realizada através do emprego do Programa Bayes (Pella e Masuda, 2001) que conduz as análises através da utilização do método de Cadeias de Monte Carlo Markov (MCMC) e gera estimativas para as probabilidades de contribuição de cada colônia para a área de alimentação estudada. Este método foi aplicado através de dois modelos distintos: o primeiro (B1) a partir de probabilidades iguais de contribuição para cada colônia de desova e o segundo (B2), a partir de probabilidades proporcionais ao tamanho das áreas de desova que contribuem para a amostra estudada. Em cada análise, utilizaram-se 20.000 cadeias, sendo a primeira metade destas descartada, e as estimativas aqui apresentadas, baseadas apenas na segunda metade destas. Para confirmação da convergência entre as cadeias de Monte Carlo Markov (MCMC), utilizou-se o diagnóstico de Gelman e Rubin obtido para todas as análises através do emprego do programa BAYES (Pella e Masuda, 2001).

Para verificar os resultados obtidos em B1 foi realizado um teste do $\mathrm{X}^{2}$ através do programa CHIRXC (Zaykin e Pudovkin, 1993), onde se calculou o número esperado de tartarugas, caso cada colônia contribuisse com a mesma quantidade de indivíduos $\left(\mathrm{n}^{\mathrm{o}}\right.$ de indivíduos analisados $/ \mathrm{n}^{\circ}$ de praias de desova analisadas). Para o teste do $\mathrm{X}^{2}$ realizado a partir dos resultados de B2 foram calculados o número esperado de tartarugas de acordo com o número de fêmeas anidadoras ( $\mathrm{n}^{\circ}$ de fêmeas em cada praia de desova $/ \mathrm{n}^{\circ}$ total de fêmeas * $\mathrm{n}^{0}$ de indivíduos analisados). Estes resultados foram comparados às estimativas obtidas em B1 e B2 através de uma regressão linear realizada pelo programa Bioestat 3.0 (Ayres, 2003). Foram consideradas como áreas de desova, aquelas que contribuiam com ao menos um indivíduo nos resultados obtidos através da MSA (B1 e 
B2). Para cada teste foram realizadas 10.000 simulações e utilizou-se o nível de significância de 0,05\%.

\subsubsection{Análise Bayesiana: Many-to-Many}

A Análise "Many-to-Many” (MM) foi realizada utilizando-se o programa R 2.9.0 (The R Foundation for Statistical Computing, 2009) implementado através da ferramenta Winbugs 1.4.3 (Lunn, 2000). Para esta análise empregaram-se os dados obtidos em Cananéia, os outros sítios de alimentação estudados no Atlântico Sul Ocidental (Almofala, Ubatuba e Uruguai) e praias de desova estudadas na Base Atlântica (MM1). Atol das Rocas, Fernando de Noronha e Arvoredo foram excluídos desta análise por apresentarem números amostrais muito reduzidos.

A mesma análise foi conduzida a partir de todas as áreas de alimentação e desova descritas na literatura para o Oceano Atlântico (MM2; Tabela 07). Os resultados foram obtidos a partir de 6 e 10 cadeias de Monte Carlo Markov (MCMC) respectivamente.

O diagnóstico de Gelman e Rubin foi utilizado para confirmar a convergência entre cadeias MCMC (Gelman e Rubin, 1992), sendo obtido pelo programa R 2.9.0 (The R Foundation for Statistical Computing, 2009).

Tabela 07. Áreas de desova e de alimentação utilizadas na análise "Many-to-Many”, números amostrais, número de haplótipos registrados, diversidade haplotípica e nucleotídica observada em cada região.

$\begin{array}{cccccc}\text { Desova } & \mathbf{N} & \text { Haplotipos } & \mathbf{H} & \boldsymbol{\pi} & \text { Referências } \\ \text { Flórida } & 24 & 6 & 0.5616 & 0.001258 & \text { Encalada, 1996 } \\ \text { Costa Rica } & 433 & 5 & 0.1627 & 0.003181 & \text { Bjorndal, 2005 } \\ \text { Aves } & 85 & 5 & 0.2091 & 0.004288 & \text { Encalada, 1996 } \\ \text { México } & 20 & 7 & 0.8158 & 0.005044 & \text { Encalada, 1996 } \\ \text { Atol das Rocas } & 53 & 7 & 0.5196 & 0.002492 & \text { Bjorndal, 2006 } \\ \text { Trindade } & 99 & 7 & 0.5034 & 0.001174 & \text { Bjorndal, 2006 } \\ \text { Ascensão } & 70 & 10 & 0.2890 & 0.00075 & \text { Formia, 2007 } \\ \text { Bioko } & 50 & 2 & 0.1837 & 0.000764 & \text { Formia, 2002 } \\ \text { Guiné Bissau } & 70 & 1 & 0 & 0 & \text { Formia, 2002 } \\ \text { São Tomé/Prin. } & 26 & 7 & 0.5380 & 0.002844 & \text { Formia, 2006 } \\ \text { Suriname } & 15 & 3 & 0.2091 & 0.004288 & \text { Encalada, 1996 } \\ & & & & & \\ \text { Alimentação } & & & & & \\ \text { Uruguai } & 114 & 10 & 0.6579 & 0.002363 & \text { Caraccio, 2008 }\end{array}$




$\begin{array}{cccccc}\text { Ubatuba } & 113 & 10 & 0.4460 & 0.002047 & \text { Naro-Maciel, 2005 } \\ \text { Almofala } & 117 & 13 & 0.7168 & 0.007607 & \text { Naro-Maciel, 2005 } \\ \text { Cananéia } & \mathbf{2 1 9} & \mathbf{1 0} & \mathbf{0 . 5 3 9 3} & \mathbf{0 . 0 0 2 1 3 8} & \text { Este trabalho } \\ \text { Barbados } & 60 & 8 & 0.7734 & 0.010274 & \text { Luke, 2004 } \\ \text { Bahamas } & 79 & 6 & 0.3703 & 0.006146 & \text { Lahanas, 1998 } \\ \text { C. do Norte } & 106 & 12 & 0.7290 & 0.005274 & \text { Bass, 2006 } \\ \text { Flórida } & 62 & 6 & 0.4855 & 0.003097 & \text { Bass \& Witzell, 2000 } \\ \text { Nicarágua } & 60 & 2 & 0.1831 & 0.003806 & \text { Bass, 1998 }\end{array}$

Com o intuito de avaliar a influência da distância existente entre as praias de desova e Cananéia na contribuição de cada uma destas áreas, foi realizada uma regressão linear entre as estimativas de contribuição obtidas através de B1 e B2 e a distância geográfica, em kilômetros, em relação à área de estudo. A regressão linear foi conduzida através do programa Bioestat 3.0 (Ayres, 2003) e as distâncias entre as regiões foram calculadas a partir da ferramenta Great Circle Distance dísponível no GPS Visualizer do programa Google Earth $4.3 ®$, que fornece a distância geográfica, em kilômetros, entre dois pontos, levando-se em conta a superficie esférica do planeta.

Cabe ressaltar que, as análises de estoque misto (MSA) e "Many-to-Many" descritas neste capítulos foram realizadas no Sackler Institute for Comparative Genomics do American Museum of Natural History, NY, durante estágio realizado sob a orientação da Profa. Dra. Eugenia Naro-Maciel.

\subsection{Resultados}

\subsubsection{Testando a hipótese de "estoque misto"}

A comparação realizada entre Cananéia e as praias de desova que potencialmente contribuem para seu estoque rejeitou a homogeneidade entre estas, através do teste exato de diferenciação ( $p=0.000 ; \alpha=0.05 \%$ ), teste do $X^{2}$ e através da comparação par a par entre estimativas de Fst e Фst para cada área de desova. (Tabela 08).

Estes resultados também indicaram não haver diferença entre as colônias de Atol das Rocas e Fernando de Noronha e, Ilhas Aves e Suriname, e por este motivo, aliado à proximidade geográfica exibida entre estas, tais amostras foram agrupadas para a realização das análises seguintes, assim como para São Tomé e Príncipe. 
Tabela 08. Comparação par a par entre as áreas de desova descritas na literatura e Canenéia. A) valores de $\mathrm{X}^{2}$. B) valores de $F$ st e C) valores de (థst. A significância do valor de $p<0.05$ é indicada como *, $p<0.001$ como ** e $p<0.0001$ como $* * *$

\begin{tabular}{|c|c|c|c|c|c|c|c|c|c|c|}
\hline$x^{2}$ & Atol/Noronh & ha Trindade & Ascenção & Bioko & G. Bissau & $\begin{array}{l}\text { S. } \\
\text { T./Princ. }\end{array}$ & México & Flórida & $\begin{array}{l}\text { Costa } \\
\text { Rica }\end{array}$ & Aves/Suriname \\
\hline Cananéia & $58,10^{* * \star}$ & $76,03^{* * *}$ & $66,46^{* \star \star}$ & $249,72^{\text {***}}$ & $26,94^{*}$ & $46,47^{* *}$ & $210,56^{\star * *}$ & $232,70^{* * *}$ & $260^{\star * *}$ & $91,58^{* \star *}$ \\
\hline Fst & Atol/Noronha & Trindade & Ascenção & Bioko & G. Bissau & S.T/Princ. & México & Flórida & $\begin{array}{l}\text { Costa } \\
\text { Rica }\end{array}$ & Aves/Suriname \\
\hline Cananéia & $0.07231^{* * *}$ & $0.08365^{\star \star *}$ & $0.09990^{\star \star * *}$ & $0.08722^{* \star \star *}$ & $0.19677^{\star \star \star \star}$ & $0.04381^{* * *}$ & * $0.35889^{* \star *}$ & $0.45275^{\star \star * *}$ & ** $0.68537^{\star * \star}$ & $0.44733^{\star \star *}$ \\
\hline Фst & Atol/Noronha & Trindade & Ascenção & Bioko & G. Bissau & S.T/Princ. & México & Flórida & $\begin{array}{l}\text { Costa } \\
\text { Rica }\end{array}$ & Aves/Suriname \\
\hline Cananéia & $0.12442^{\star \star k}$ & $0.16900^{\star \star \star}$ & $0.11979^{\star \star \star}$ & $0.05616^{\star \star \star}$ & $0.15962^{\star \star \star}$ & $0.08368^{*}$ & $0.83797^{\star \star \star *}$ & $0.88116^{* * * *}$ & $0.83103^{* * *}$ & $0.40894^{* * *}$ \\
\hline
\end{tabular}




\subsubsection{Análise de Estoque Misto: ML e Bayes}

A MSA conduzida através do método da máxima verossimilhança (ML) e os intervalos de confiança, construídos através do método de bootstrapping com reamostragem de 1.000 vezes estão na Figura 12.

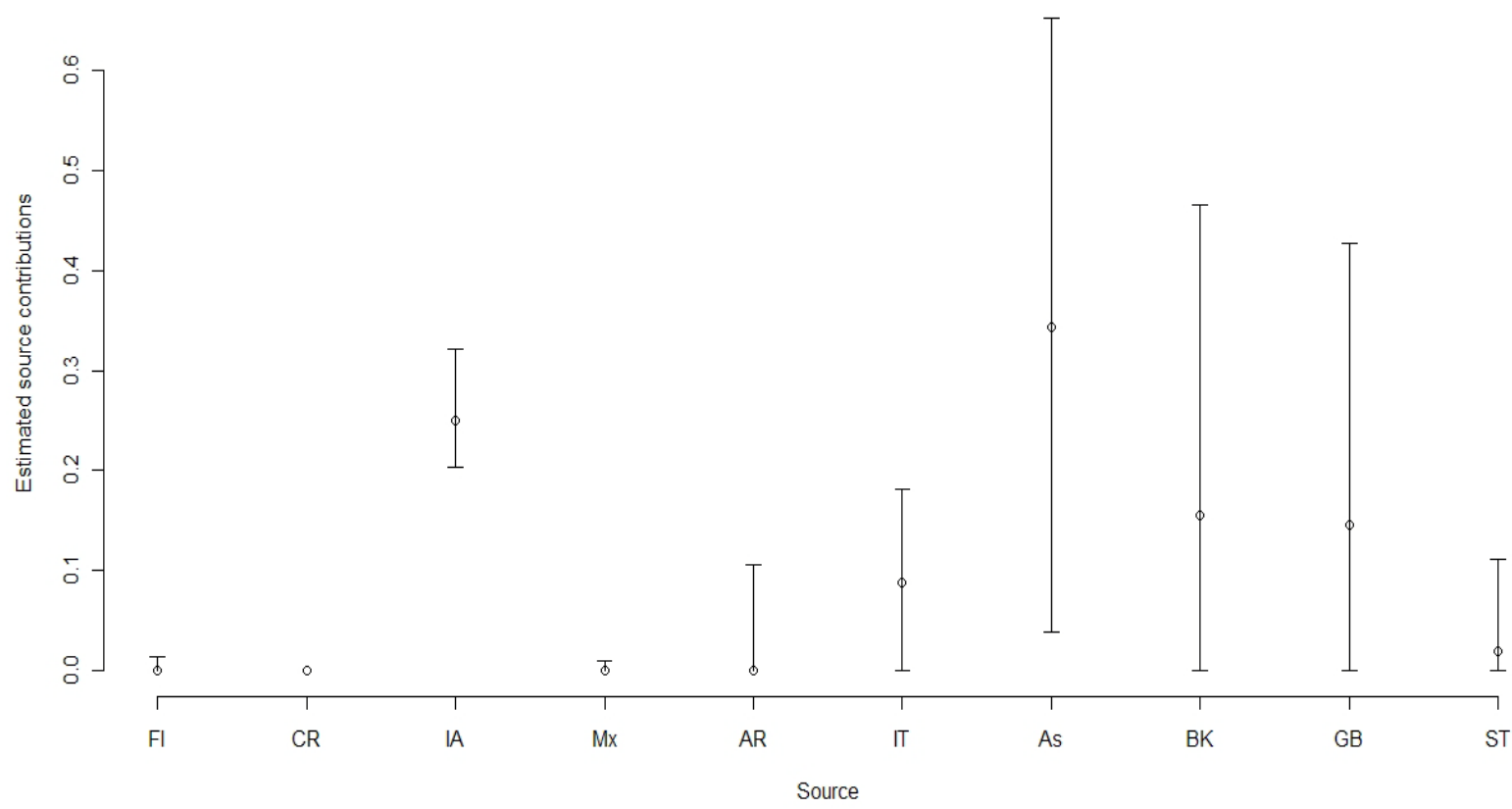

Figura 12. Estimativas de contribuição (método ML) de cada área de desova (círculos) para a população de Cananéia e seus respectivos intervalos de confiança (retas). (Fl:Flórida, CR:Costa Rica, IA: Ilhas Aves e Suriname, Mx: México, AR: Atol das Rocas e Fernando de Noronha, IT: Ilha de Trindade, As: Ilhas Ascensão, BK: Bioko, GB: Guiné Bissau, ST: São Tomé e Principe, Sn: Suriname.

\subsubsection{Análise Bayesiana: Many-to-one}

Os resultados de MSA realizada através do programa Bayes (B1) para probabilidades de contribuições iguais provenientes de cada praia de desova estão descritos na Tabela 09, e aqueles referentes às probabilidades de contribuição proporcionais ao número de fêmeas (B2), na Tabela 10.

Tabela 09. Estimativas de contribuição de cada estoque para a região de Cananéia, a partir de probabilidades iguais de contribuição (B1) obtidos a partir de 20.000 MCMC, valores dos limites inferior (2,5\%) e superior do intervalo de confiança (95\%) e o diagnóstico de Gelman e Rubin para cada estimativa (GR). 


\begin{tabular}{cccccc} 
Estoque & B1 & D. Padrão & $\mathbf{2 , 5 \%}$ & $\mathbf{9 7 , 5 \%}$ & GR \\
\hline \hline Flórida & 0.0015 & 0.0033 & 0 & 0.0115 & 1.00 \\
Costa Rica & 0.0023 & 0.0041 & 0 & 0.0143 & 1.00 \\
I.Aves/Suriname & 0.2711 & 0.0321 & 0.2109 & 0.3361 & 1.00 \\
México & 0.0013 & 0.0033 & 0 & 0.0112 & 1.00 \\
Atol/F. Noronha & 0.0048 & 0.0147 & 0 & 0.0481 & 1.00 \\
Trindade & 0.0416 & 0.0396 & 0 & 0.1436 & 1.00 \\
Ascensão & 0.5190 & 0.1346 & 0.2329 & 0.7167 & 1.01 \\
Bioko & 0.0466 & 0.0867 & 0 & 0.3151 & 1.02 \\
Guiné Bissau & 0.0792 & 0.1122 & 0 & 0.3645 & 1.01 \\
S. Tomé/Princ. & 0.0326 & 0.0372 & 0 & 0.1304 & 1.00
\end{tabular}

Tabela 10. Estimativas de contribuição de cada estoque para a região de Cananéia, a partir de probabilidades proporcionais ao número de fêmeas registradas para cada área de desova (B2), obtidos a partir de 20.000 MCMC, valores dos limites inferior (2,5\%) e superior do intervalo de confiança (95\%) e o diagnóstico de Gelman e Rubin para cada estimativa (GR).

\begin{tabular}{cccccc} 
Estoque & B2 & D. Padrão & $\mathbf{2 , 5 \%}$ & $\mathbf{9 7 , 5 \%}$ & GR \\
\hline \hline Flórida & 0.0004 & 0.0017 & 0 & 0.0052 & 1.00 \\
Costa Rica & 0.0074 & 0.0063 & 0.0002 & 0.0233 & 1.00 \\
I.Aves/Suriname & 0.2757 & 0.0322 & 0.2159 & 0.3412 & 1.00 \\
México & 0.0006 & 0.0022 & 0 & 0.0076 & 1.00 \\
Atol/F. Noronha & 0.0001 & 0.0016 & 0 & 0 & 1.07 \\
Trindade & 0.0383 & 0.0388 & 0 & 0.1361 & 1.01 \\
Ascensão & 0.5722 & 0.1442 & 0.2378 & 0.7448 & 1.01 \\
Bioko & 0.023 & 0.0779 & 0 & 0.3136 & 1.11 \\
Guiné Bissau & 0.0762 & 0.1209 & 0 & 0.3921 & 1.02 \\
S. Tomé/Princ. & 0.0056 & 0.0206 & 0 & 0.0697 & 1.06
\end{tabular}

Em todas as análises os valores obtidos através do diagnóstico de Gelman e Rubin variaram entre 1.00 e 1.11, sendo inferiores a 1.2 e, portanto, indicando a convergência entre cada cadeia para a obtenção das probabilidades a posteriori, como recomendado por Pella e Masuda (2001). Os resultados obtidos em B1 e B2 apresentaram-se altamente correlacionados (Fig. 13). 


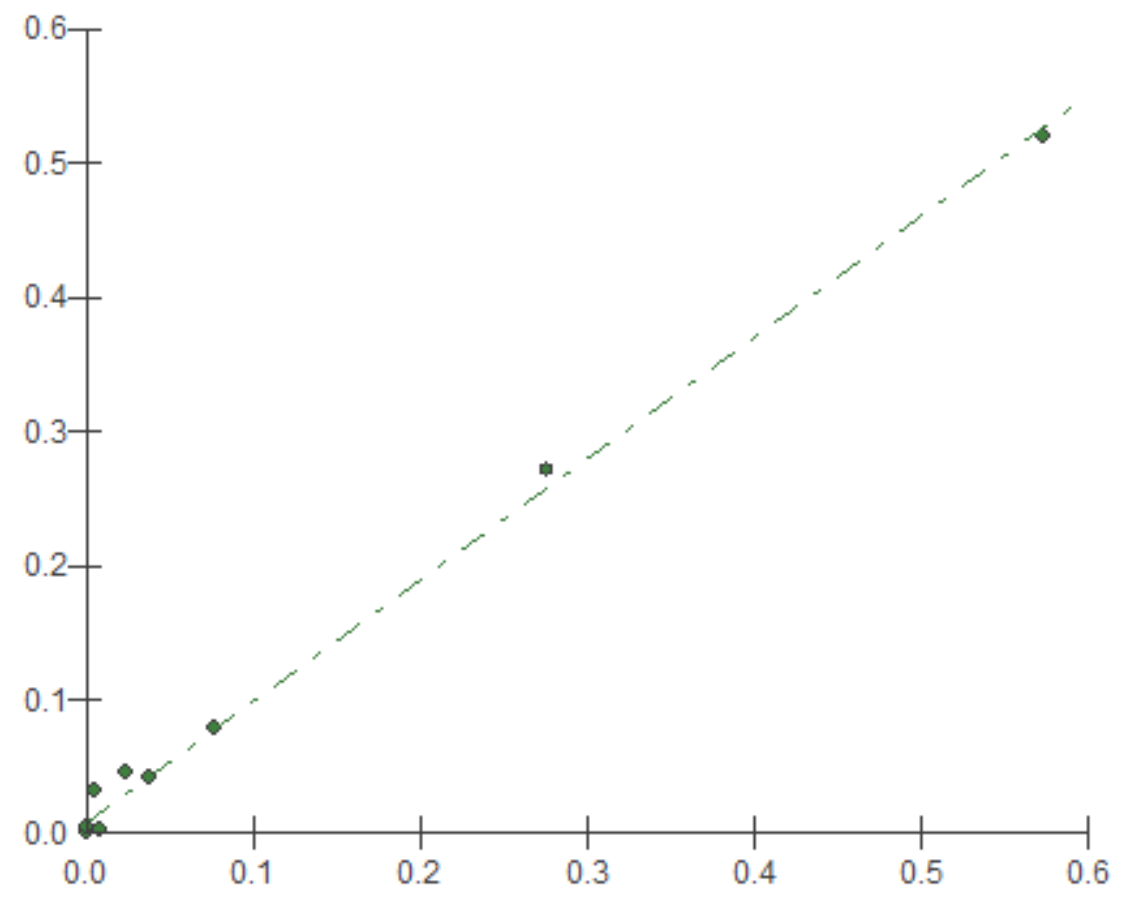

Figura 13. Regressão linear entre os resultados obtidos a partir das análises B1 e B2. $\left(\mathrm{r}^{2}=0.9013 ; p=\right.$ 0.000).

Os principais estoques contribuintes, nas três análises conduzidas formam as Ilhas Ascensão e Ilhas Aves/Suriname. Para as outras colônias, observou-se discordância entre os dados obtidos pelos diferentes métodos. Os resultados da ML indicam seis contribuintes entre os dez potenciais estoques testados enquanto que em B1 e B2, os resultados indicaram que os dez estoques testados contribuíram ao menos com um indivíduo para o estoque misto de Cananéia.

Os intervalos de confiança maiores foram encontrados na análise ML enquanto que os menores foram calculados pelo método B2, ou seja, levando-se em conta o número de fêmeas existente em cada praia de desova.

A relação entre a distância geográfica das áreas de desova ao sítio de alimentação analisado e as estimativas de contribuição gerada pelas análises bayesianas B1 e B2 não foram significativas (B1: $\mathrm{r}^{2}=0, p=0.52$ e B2: $\mathrm{r}^{2}=0, p=0.56$; Fig. 14). 

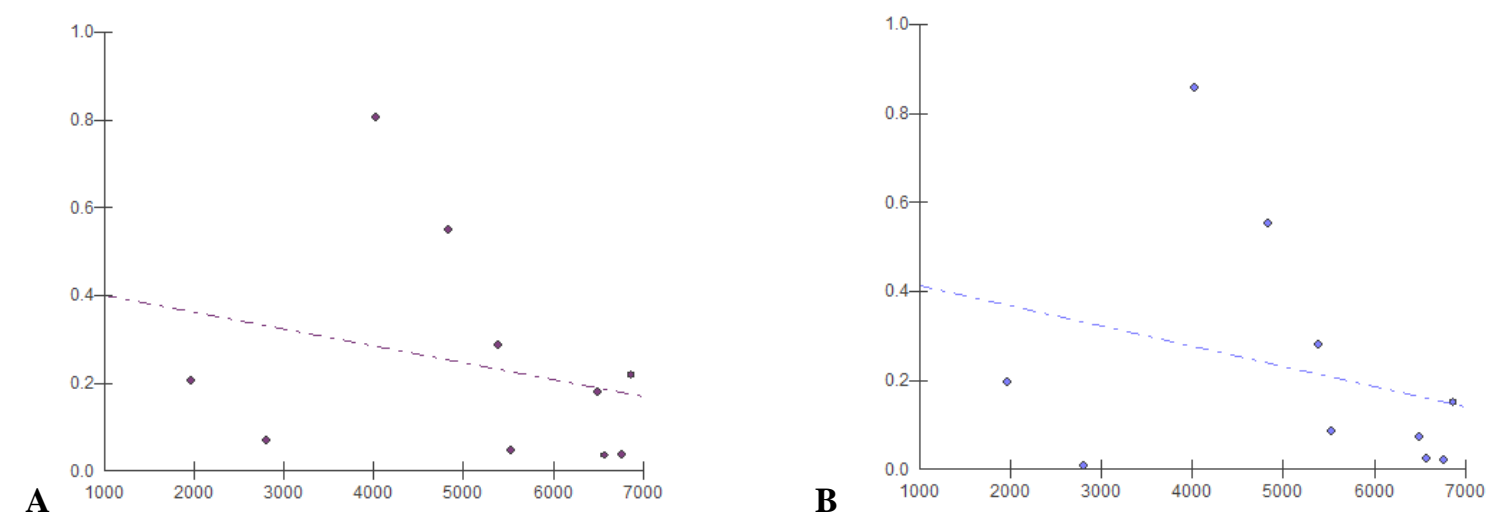

Figura 14. Regressão linear conduzida a partir das estimativas de B1 (A) e B2 (B) e a distância geográfica existente entre as praias de desova e a região de Cananéia.

\subsubsection{Análise Bayesiana: Many-to-Many}

O método "Many-to-Many" conduzido entre as áreas de alimentação do Atlântico Sul Ocidental (MM1) gerou os resultados descritos na Figura 12, com 10.000 iterações necessárias para atingir valores do diagnóstico de Gelman e Rubin inferiores a 1.2. Observa-se o mesmo perfil de contribuição a partir das áreas de desova para os sítios de forrageio analisados, com exceção de Almofala que mostra maior variabilidade genética.

O mesmo método foi aplicado para todas as áreas de alimentação e praias de desova estudadas no Oceano Atlântico (MM2; Fig. 15). Esta análise foi realizada a partir de 10.000 iterações, necessárias para atingir a convergência entre as cadeias. Nesta análise observou-se a nítida diferença entre as áreas de alimentação, de acordo com sua localização geográfica. Bahamas e Nicarágua mostram-se menos diversas exibindo um perfil bastante semelhante à colônia de Costa Rica sendo esta, seu estoque predominante. Áreas de alimentação localizadas na costa dos Estados Unidos exibem também constribuições semelhantes embora em frequências distintas. Para Carolina do Norte observou-se México, Costa Rica e Flórida como principais estoques enquanto que para Flórida, uma contribuição muito superior proveniente da Costa Rica, seguida de México e Flórida foram registradas.

Sítios de alimentação situados no Golfo da Guiné e em Corisco foram os mais diversos, tendo como principais colônias contribuintes as Ilhas Ascensão, seguida de Bioko, Guiné Bissau e São Tomé/Príncipe. 
Barbados apresenta como maior contribuinte a Costa Rica, porém contribuições significativa são provenientes de Aves/Suriname, Ilhas Ascensão, Trindade e México.

Cabe ressaltar ainda a composição do estoque encontrado em Atol das Rocas/Fernando de Noronha que recebem predominantemente animais de Ascensão, conforme esperado, porém as contribuições de Trindade e Ilha Aves/Suriname foram expressivas, ainda que seu número amostral não seja suficiente para corroborar tais resultados. 


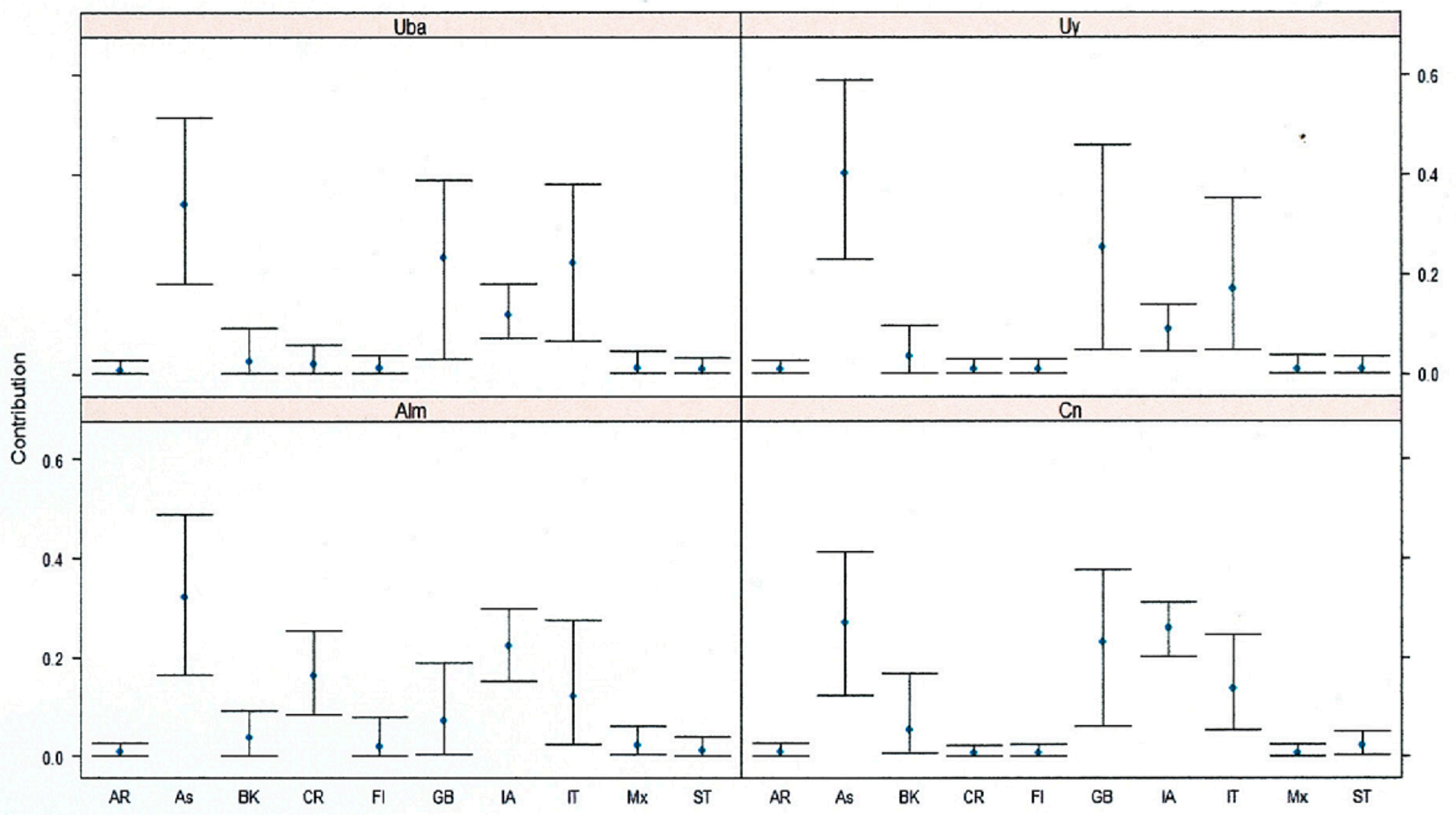

Figura 15. Estimativas de contribuição (ponto azul) e intervalos de confiança de cada área de desova (eixo X) para a população de Ubatuba (Uba), Uruguai (Uy), Almofala (Alm) e Cananéia (Cn). AR (Atol das Rocas), As (Ilhas Ascensão), BK (Bioko), Fl (Flórida), GB (Guiné Bissau), IA (Illha de Aves), IT (Ilha de Trindade), Mx (México), Sn (Suriname) e ST (São Tomé e Principe). 


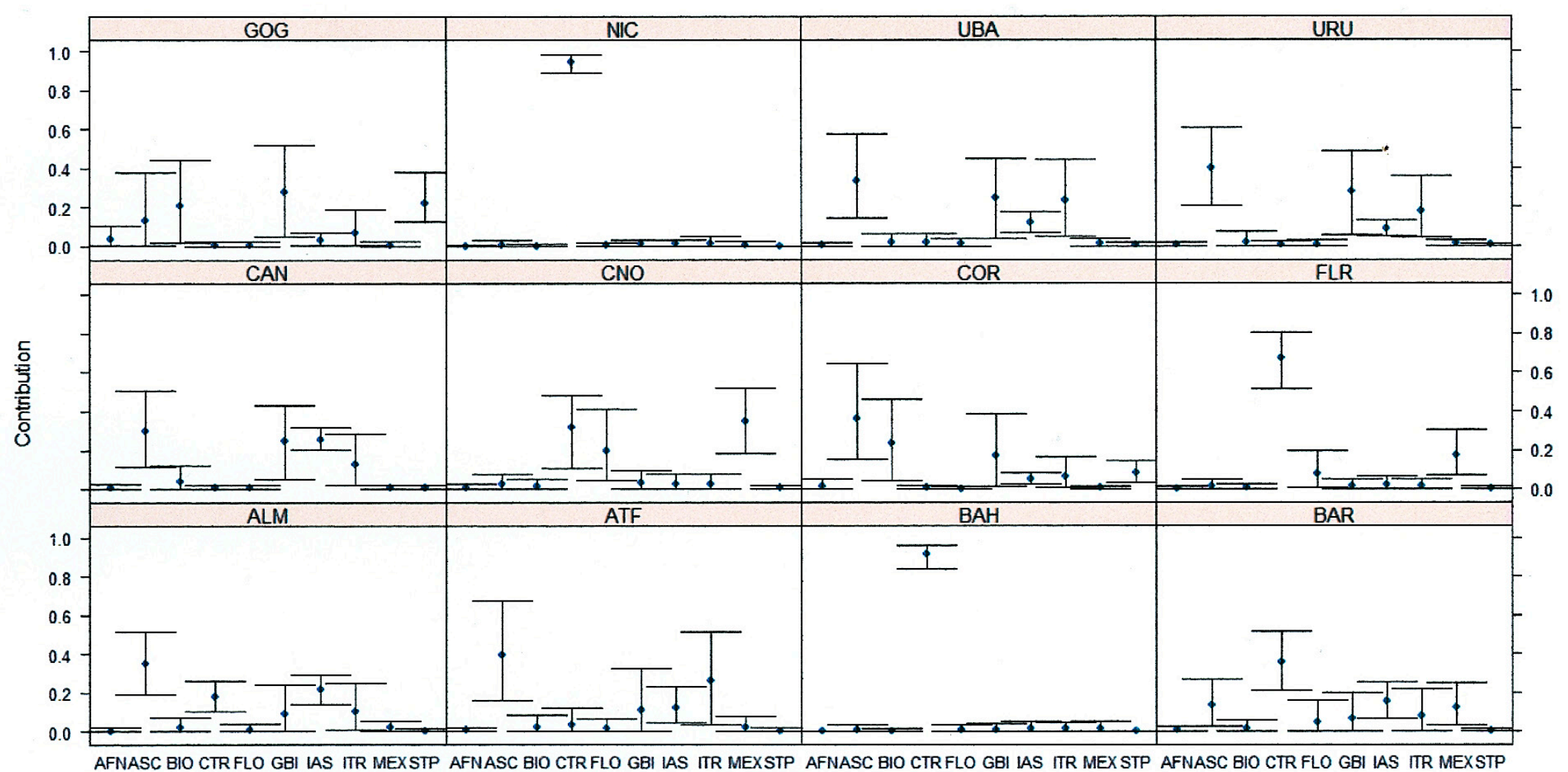

Figura 16. Estimativas de contribuição e intervalos de confiança respectivos de cada área de desova para a população de Golfo da Guiné (GOG),Nicaragua (NIC).Ubatuba (Uba). Uruguai (Uy). Cananéia (Cn), Carolina do Norte (CNO), Corisco (COR). Flórida (FLR), Almofala (ALM), A tol das Rocas/Fernando de Noronha (ATF), Bahamas (BAH) e Barbados (BAR). AFN (Atol das Rocas/Fernando de Noronha), ASC (Ilhas Ascensão), BIO (Bioko), CTR (Costa Rica), FLO (Flórida), GBI (Guiné Bissau), IAS (Ilhas Aves/Suriname), ITR (Ilha de Trindade), MEX (México), STP (São Tomé/Príncipe). 


\subsection{Discussão}

A hipótese de estoque misto foi confirmada para a região de Cananéia e permitiu que análises fossem conduzidas através de três diferentes métodos a fim de compreender a importância do referido estoque tanto para as populações de Chelonia mydas presentes no Atlântico Sul Ocidental como para esta espécie. Por se tratar de dados de mesma natureza que àqueles descritos no capítulo anterior (haplótipos distintos por pequeno número de substituições e populações distinguíveis por frequências haplótípicas) acreditamos que as estimativas de Fst fornecem índices mais realísticos e, por este motivo, mais adequado para descrever a relação entre a população presente em Cananéia e aqueles estoques descritos para as áreas de desova.

\subsubsection{Análise de Estoque Misto - Método da máxima verossimilhança}

A MSA conduzida através do método da máxima verossimilhança não gerou estimativas acuradas por apresentar intervalos de confiança extremamente amplos. A máxima verossimilhança (ML) procura encontrar uma estimativa dada a hipótese que maximize a verossimilhança dos dados observados. Este método assume as frequências observadas para cada área de desova como verdadeiras; deste modo, cada uma delas é representada exatamente como a amostra utilizada nesta análise e isto pode torná-lo tendencioso, visto que contribuições de estoques abundantes são subestimadas enquanto aquelas, provenientes de estoques mais raros ou mesmo ausentes são superestimadas (Pella \& Masuda, 2001).Este é o caso das populações de tartarugas marinhas, que geralmente são formadas por poucos haplótipos em grandes proporções e inúmeros haplótipos raros, sendo registrados, muitas vezes, apenas uma única vez, como é o caso do CM-01 e CM-24 em nossa amostra.

Através das análises qualitativas descritas no capítulo 2 desta tese e dados de telemetria provenientes da literatura (Luschi, 1998; Avens, 2004), esperava-se que as Ilhas Ascensão, que contribuiu com 63\% deste estoque misto, fossem a principal área de desova a contribuir com o estoque de Cananéia. O mesmo pode ser dito a respeito da contribuição do estoque proveniente de Ilhas Aves/Suriname em segunda posição, 
contribuindo com 26\% do estoque, devido à alta porcentagem de indivíduos registrados com o haplótipo CM-05. Estudos de marcação e recaptura e telemetria indicam que este estoque contribui com cerca de 13\% dos animais registrados em Ubatuba (Naro-Maciel, 2007) contudo não houve registros de conectividade, baseados em dados de marcação e recaptura ou provenientes de experimentos de telemetria, entre este estoque e a região de Cananéia. A continuação destas pesquisas, a longo prazo, se faz necessária para a confirmação dos resultados obtidos.

Da mesma maneira que em ML, os resultados obtidos através das análises bayesianas, a partir de probabilidades iguais de contribuição (B1) indicam as Ilhas Ascensão e Ilhas Aves/Suriname como principais contribuintes, seguido das colônias africanas e a Ilha de Trindade, que apresentaram contribuições em proporções reduzidas.

Trabalhos anteriores em áreas de alimentação na costa brasileira (Naro-Maciel, 2007) e uruguaia (Caracio, 2008) não revelaram contribuições significativas provenientes do estoque de Trindade e este resultado é controverso, por se tratar da principal área de desova de Chelonia mydas presente em águas brasileiras, recebendo cerca de 3.000 fêmeas para desova, a cada estação reprodutiva (Seminoff, 2002). O destino da maioria dos filhotes provenientes de Trindade ainda permanece desconhecido.

\subsubsection{Análise Bayesiana: Many-to-one}

A análise bayesiana atribui a cada parâmetro uma distribuição de probabilidades e um intervalo de confiança simulados através de Cadeias de Monte Carlo Markov (MCMC). Tal método permite ainda, a incorporação de informações a priori sobre a população em estudo. Parâmetros biológicos, como o tamanho das populações de desova, podem ser incorporados à análise aumentando assim a precisão dos resultados (Okuyama e Bolker, 2005) e permitindo uma visão mais realista sob o ponto de vista biológico (Bass, 2006).

Os intervalos de confiança exibidos por B1 mostraram-se razoáveis, a partir de análises conduzidas com 20.000 cadeias. Este método, pressupõe que todos os potenciais estoques contribuem com a mesma probabilidade, indiferente a qualquer outro parâmetro e isto torna seus resultados bastante conservadores. 
Por fim, B2, conduzida levando-se em conta a influência do tamanho de cada colônia de desova apresentou resultados bastante similares a B1. Da mesma forma que em B1, as análises com 20.000 cadeias geraram a diminuição dos intervalos de confiança, razão pela qual, estes foram os resultados aqui apresentados. Todas as estimativas de B1 e B2 resultaram em diagnósticos de Gelman e Rubin inferiores a 1.2. Estes valores nos indicam a convergência por comparar a variação dentro de uma única cadeia à variação total entre todas as cadeias (Bass, 2006).

Ao compararmos B1 e B2, de maneira geral observou-se menores IC em B2. A incorporação de qualquer infomação biológica a priori, tende a produzir resultados mais próximos à realidade biológica da espécie em questão, e isto foi observado neste trabalho. Por este motivo, acreditamos que as estimativas mais precisas e que portanto, poderiam contribuir de forma mais efetiva para o entendimento da composição do estoque misto de Cananéia são aquelas produzidas através do Método Bayesiano, segundo contribuições proporcionais ao tamanho das colônias de desova (B2). A incorporação de outros dados ecológicos às análises pode aumentar a confiabilidade dos resultados.

Em relação a distância geográfica existente entre as colônias e áreas de alimentação, esta não revelou qualquer relação entre as estimativas de contribuição (B1 e B2), assim como este não foi um parâmetro determinante na composição da área de alimentação de Barbados (Luke, 2004). Entretanto, Bass e Witzell (2000) demonstraram contribuições maiores das colônias adjacentes em detrimento daquelas mais distantes. Por não ser possível incorporar os dados de distância às análises conduzidas pelo programa Bayes, estes resultados foram produzidos apenas através de uma regressão linear simples, o que não indica necessariamente a distância percorrida pelos animais (Naro-Maciel, 2007). Esta discordância encontrada entre os diversos trabalhos citados pode ser solucionada com o aumento da capacidade de incorporar dados ecológicos a priori, à medida que este e outros programas de análises genéticas vão sendo aperfeiçoados e maior quantidade de dados genéticos forem produzidos.

\subsubsection{Análise Bayesiana: Many-to-Many}

Os resultados obtidos em MM1 indicam as Ilhas Ascensão como principal área de desova contribuinte para as áreas analisadas. Ubatuba, Cananéia e Uruguai mostram 
resultados bastante similares, enquanto que o estoque misto de Almofala se mostra mais diverso. Este resultado corrobora aqueles apresentados em relação à diversidade nucleotídica e haplotípica no capítulo 2 desta tese. Almofala ocupa uma posição estratégica recebendo juvenis provenientes de praias de desova do Atlântico Norte e Sul, enquanto que Ubatuba, Cananéia e Uruguai apresentam estoques formados, quase que em totalidade, por haplótipos do Atlântico Sul. De acordo com a localização geográfica destes sítios e a partir de dados de marcação e recaptura (Projeto Tamar, dados não publicados) acreditamos que tais regiões compõem um corredor migratório importante para as tartarugas provenientes das áreas de desova do Atlantico Sul. Segundo esta hipótese, tais regiões funcionariam como provedoras de recursos energéticos e regiões de descanso para estes animais durante seus movimentos migratórios. A equipe organizadora da ASO (reunião de especialistas em tartarugas marinhas do Atlântico Sul Ocidental, que engloba pesquisadores que atuam na costa brasileira, uruguaia e argentina) trabalha atualmente na elaboração de um documento que concretize a formação de áreas protegidas marinhas integradas nestes três países a fim de proteger este corredor e permitir o reestabelecimento das populações que se utilizam destas áreas para reprodução, alimentação e desenvolvimento.

Em MM2, os resultados apresentados para Bahamas mostraram-se coincidentes àqueles descritos por Bass (2006), usando ML e Análise Bayesiana (Many-to-One), sendo uma área de alimentação primariamente composta por tartarugas provenientes da Costa Rica exibindo uma baixa diversidade haplotípica. Há indicações de outras contribuições porém estas são bastante reduzidas. Nicarágua é a única área de alimentação composta por adultos (Bass, 2006) e pelos resultados aqui demonstrados, parece ser composta quase que em sua totalidade por indivíduos provenientes da área de desova adjacente, ou seja, a Costa Rica. Isto indica um comportamento distinto nos animais desta faixa etária em detrimento dos outros sítios compostos por juvenis.

Em relação a influência das correntes marinhas no recrutamento de juvenis para o ambiente nerítico este pode ser um parâmetro importante no entendimento da composição dos estoques (Luke, 2004), porém os métodos e testes estatísticos existentes atualmente ainda são incapazes de incorporá-los às análises aqui apresentadas. 


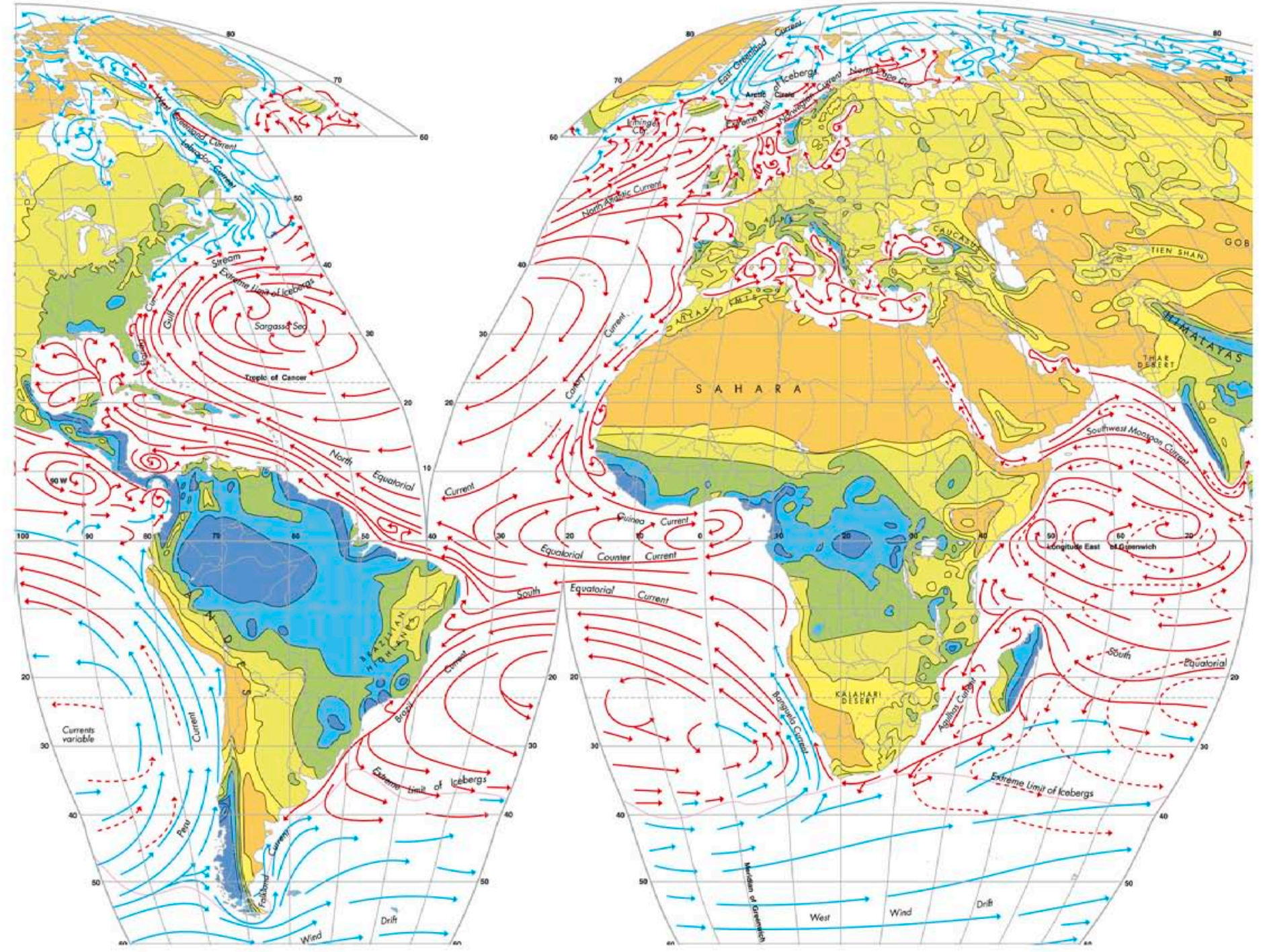

Figura 17. Mapa indicando as principais correntes do Oceano Atlântico 
Inúmeros autores têm sugerido a grande importância das correntes no ciclo de vida das tartarugas marinhas (Luke, 2004, Bass, 2006, Naro-Maciel, 2007). A alta diversidade registrada em Barbados é atribuída aos diversos sistemas de correntes que atuam nesta região: Norte Equatorial, Sul Equatorial e a Corrente das Guianas (Luke, 2004). Estes sistemas são altamente complexos apresentando variações temporais e sazonais. Somente dados obtidos a longo prazo, podem permitir aos pesquisadores entender melhor as complexas interações entre padrões de correntes e tamanhos populacionais, parâmetro que também sofre flutuações, no recrutamento de animais para áreas de alimentação.

O comportamento ds tartarugas marinhas é outro fator que não pode ser negligenciado. Enquanto Caretta caretta exibe a tendência de utilizar sítios de alimentação adjacentes às praias de desova, o mesmo não se aplica a Chelonia mydas. Bass, (2006) sugere que o recrutamento de juvenis em habitats de alimentação é resultante da interação entre as correntes oceânicas e eventos de colonização que ocorreram no passado, que assim modelaram a distribuição de áreas de desova e, em menor rigor, as áreas de alimentação.

No presente trabalho, as correntes oceânicas desempenham um papel bastante evidenciado pela contribuição proporcionalmente aumentada de animais provenientes de Ascensão. Hipoteticamente os filhotes seriam trazidos desta ilha, para a costa brasileira por ação da Corrente Norte Equatorial (Figura 15) porém um conhecimento mais refinado do sistema de correntes que banha a região de Cananéia, assim como a atuação de outros fatores sinergisticamente se fazem necessários para o completo entendimento deste padrão de recrutamento.

Por incorporar toda a informação possível da metapopulação formada por todas as populações analisadas em conjunto, nas estimativas de movimento, MM refina aqueles resultados gerados pela MSA, centralizada apenas em uma área de alimentação.

A estabilidade temporal destes dados permanece desconhecida e a continuidade das amostragens, nas diferentes colônias e áreas de alimentação possibilitará sua verificação. Fêmeas em idade reprodutiva visitam áreas de desova em ciclos de dois a três anos e nenhum padrão similar foi encontrado para descrever a frequência destes animais em áreas de forrageio. Bass, 2004 não encontrou diferenças significativas analisando áreas de alimentação de tartarugas cabeçudas na Carolina do Norte, durante três anos consecutivos. No presente trabalho, verificamos haver diferença na 
composição haplotípica entre os quatro anos de amostragem. Uma possível flutuação nesta composição, entre os diferentes anos permanece incerta, sendo necessário um período de amostragem mais longo a fim de confirmar esta hipótese.

Os resultados indicam claramente a importância da região estudada, que aliada às demais áreas de alimentação localizadas no Atlântico Sul Ocidental respondem pelo conteúdo energético que mantém as colônias de Ilhas Ascensão e Ilhas Aves/Suriname. Além disto, ainda que em proporções reduzidas, recebem animais das colônias localizadas em águas brasileiras e africanas, contribuindo também para a manutenção destas populações.

O aprofundamento do conhecimento e a manutenção destas regiões ainda pouco compreendidas (Bowen, 2007) são fundamentais para a preservação dos estoques populacionais e para o aumento das populações, visto que são responsáveis pela nutrição e desenvolvimento de juvenis e subadultos, participando deste modo da manutenção das colônias de desova dispersas no Oceano Atlântico.

As tartarugas marinhas foram descritas como importantes transportadores de recursos energéticos entre os ecossistemas marinho e costeiro, utilizando-se dos recursos obtidos nestas regiões que, são posteriormente depositados em áreas de desova sob a forma de ninhos, que darão origem aos seus descendentes (Bjorndal, 2000). No caso de Cananéia, estes animais, em sua fase juvenil fazem uso de recursos alimentares de sua preferência, que ocorrem em abundância em bancos de algas e agiospermas marinhas, conhecidos como "pasto marinho", para seu crescimento e desenvolvimento. Deste modo a região tem papel crucial no ciclo de vida destes animais e na manutenção de suas populações no Atlântico Sul Ocidental. 


\section{Capítulo 4}

\subsection{A utilização de dados moleculares na elaboração de planos de manejo e conservação}

\subsection{Introdução}

Um dos problemas fundamentais que os biólogos enfrentam quando prestam aconselhamento a gestores ambientais é a forma de caracterizar determinados aspectos biológicos, levando em conta incertezas e estimativas de erros e a falta de conhecimento relacionados a espécie e trabalho desenvolvidos (Harwood, 2000).

O completo entendimento sobre uma espécie ameaçada é essencial na construção de estratégias que efetivamente contribuam para a sua conservação. O status taxonômico, sua área de distribuição e determinados aspectos demográficos e ecológicos são fundamentais na elaboração de propostas que contribuam para a manutenção das espécies ameaçadas. O escasso conhecimento acerca destes temas pode levar a erros que, em lugar de contribuir para a sua preservação, comprometem seriamente o futuro da espécie estudada.

O status taxonômico ainda é incompletamente resolvido para inúmeros organismos, particularmente entre plantas inferiores e invertebrados, mas também se aplica a animais de grande porte, como por exemplo veados e lobos (Frankham, 2004). Decisões erradas podem ser tomadas quando determinada espécie está incorretamente classificada e isto inclui ser negligenciada em detrimento de outras que não sofrem ameaça, ou mesmo de híbridos, causando o direcionamento de recursos econômicos, muitas vezes escassos, para a proteção de espécies que não estão ameaçadas.

Algumas descrições de espécies baseiam-se unicamente na distribuição geográfica de um pequeno número de traços morfológicos, cuja base genética é ainda desconhecida (Ward, 2000). As girafas atuais são um exemplo bastante claro disto. Giraffa camelopardalis era considerada a única espécie existente de girafa até recentemente, quando Brown, (2007) analisou sequências de DNA mitocondrial e loci de microssatélites nucleares que revelaram a existência de seis linhagens distintas com pouca evidência de acasalamento entre elas. Algumas destas linhagens parecem se manter separadamente das outras, na ausência de barreiras ao fluxo gênico, por 
diferenças em seus períodos reprodutivos ou pela escolha de parceiros através de diferentes padrões de pelagem.

Decisões em manejo, que assumem certas probabilidades sabidamente incertas como exatas, podem acarretar resultados inesperados ou mesmo indesejáveis. Maguirre (1987) ao analisar as populações do rinoceronte de Sumatra Dicerorhinus sumatrensis, espécie listada como criticamente ameaçada de extinção, propôs três opções de manejo: reprodução em cativeiro, translocação de indivíduos e a formação de uma nova reserva. Entretanto, não conseguiu atingir os resultados almejados, ou seja, aumentar o número de indivíduos nas populações manejadas, por não levar em conta uma série de fatores como a perda de habitat, incidentes demográficos, doenças e a caça, que ainda é a principal ameaça sofrida por esta espécie (Regan, 2005). Ao aplicar informações obtidas através de estudos, em ações conservacionistas é crucial levar em conta as incertezas que encontramos em alguns parâmetros, pois estas podem ter um efeito substancial sobre os resultados esperados.

\subsubsection{A manutenção da diversidade genética}

A preservação da diversidade genética se tornou o objetivo da maioria dos programas de conservação e conhecer a diversidade dentro e entre as populações naturais é o primeiro passo (Bekessy, 2002). O entendimento de como a variação genética de uma espécie está distribuída é essencial à sua conservação. Atualmente, o conhecimento da estruturação genética é entendido como uma etapa fundamental para a realização de programas conservacionistas. A identificação de unidades de manejo (MU) ou unidades significativamente evolutivas (ESU) podem se basear em dados moleculares, como por exemplo na divergência das frequências alélicas de um locus nuclear ou mitocondrial (Moritz, 1994), indicando áreas ou populações de maior ou menor relevância na preservação dos táxons em estudo, permitindo assim o desenvolvimento de estratégias efetivas de conservação. A determinação da diversidade genética e da estrutura de populações naturais também é fundamental para o estabelecimento de normas de exploração econômica racional, ao se tratar de espécies de interesse comercial.

A consevação de espécies depende da manutenção de sua diversidade no habitat (in situ) e de reservas genéticas (ex situ), como por exemplo animais em cativeiros ou, 
no caso de plantas, os bancos de germoplasma (Cavallari, 2004). Tais reservas devem ser consideradas parte importante das estratégias conservacionistas, dado o ritmo acelerado de destruição de diversos habitats, provocados por uma grande variedade de atividades antrópicas.

Um dos objetivos básicos da preservação in situ é a manutenção de variabilidade suficiente para possibilitar a evolução contínua em ecossistemas, sendo que o maior número possível de individuos deve ser mantido, abrangendo diversas localidades geográficas e toda amplitude ecológica da espécie. Dado ao grau avançado de perturbação e destruição de alguns habitats naturais, esta tarefa nem sempre é possível, levando os pesquisadores a buscarem estratégias que efetivamente contribuam para a manutenção de uma determinada espécie, ainda que sua variabilidade esteja comprometida. O cruzamento com espécies próximas é uma estratégia, por vezes utilizada, a fim de aumentar a variabilidade de uma espécie, porém deve ser executada com muito cuidado, havendo necessariamente uma avaliação preliminar, com base experimental, a fim de assegurar que os híbridos sejam viáveis e férteis antes de sua implementação (Frankham, 2004).

A manutenção de espécies em cativeiro, muitas vezes é a única alternativa para espécies que tem seu habitat natural destruído (Frankham, 2004) e durante os últimos 20 anos os parques zoológicos, principais centros de reprodução em cativeiro, têm alterado profundamente sua visão a respeito dos animais, voltando sua atenção para o estabelecimento de programas de conservação através da reprodução em cativeiro (Ballou e Foose,1996). A análise de pedigrees, o histórico de cada indivíduo, experimento de cruzamento e o monitoramento da saúde dos animais em cativeiro são coletados e mantidos em um banco de dados que pode ser acessado por parques zoológicos do mundo inteiro (Frankham, 2004).

A reintrodução de espécies mantidas em cativeiro requer diversas fases como o exame das populações selvagens, a fim de confirmar a necessidade de reintrodução, a criação e manutenção de populações saudáveis e em tamanho adequado para reintrodução (Frankham, 2002). Durante todo o processo, análises genéticas são essenciais para monitorar a viabilidade e, após a reintrodução, recomenda-se o monitoramento genético da população selvagem, com o intuito de verificar se os resultados foram alcançados. Alguns programas de reintrodução, como por exemplo da espécie arbustiva Zieira prostata foram abandonados após as primeiras análises que 
indicaram que a espécie mantida em cativeiro era distinta daquela que deveria ser recuperada na natureza (Hogbin,2000).

Felinos, ursos, elefantes, rinocerontes, papagaios e baleias são alguns exemplos de animais-alvo de caça e comércio ilegal e técnicas moleculares também contribuem para a conservação destas espécies, por elucidar alguns de seus aspectos biológicos. Análise de DNA mitocondrial de amostras de carne de baleia, encontrada nos mercados japoneses e coreanos indicaram não serem proveniente da espécie Minke, a única em que a caça ainda é permitida e sim de baleias azul, jubarte e bryde. Além disto, foram detectadas em tais amostras, carne de golfinho e cavalo o que indica que, não apenas o comércio ilegal existe, mas também que seus consumidores muitas vezes são ludibriados (Dizon, 2000).

Definir unidades de manejo com base unicamente em parâmetros genéticos pode facilmente levar a decisões incorretas de manejo. A genética da conservação é bem aplicada quando a análise de seus dados facilita a tomada de decisão quanto ao futuro das espécies.

No presente trabalho, pretendeu-se utilizar as informações obtidas através da análise populacional de tartarugas verdes, realizada em Cananéia, de forma a corroborar a necessidade de preservação desta região, contribuindo para a complementação do plano de manejo existente para o Parque Estadual Ilha do Cardoso e na elaboração de outros planos de manejo para a região, incluindo além destes, diversos outros parâmetros biológicos e ecológicos já conhecidos no intuito de manter a região o mais intacta possível.

\subsection{Objetivos}

Com base nos dados moleculares a nas informações biológicas obtidos ao longo deste estudo, tivemos como objetivos:

- Aplicar os resultados das análises genéticas aqui realizadas, de forma prática, contribuindo na proposta de um plano de manejo para a região de Cananéia;

- Utilizar os resultados obtidos neste trabalho para corroborar a necessidade de conservação da região estudada, implementando, entre outros, o plano de manejo existente para o Parque Estadual Ilha do Cardoso. 
- $\quad$ Discutir o papel dos dados moleculares e suas aplicações práticas, aliado a outros parâmetros biológicos, na preservação de espécies ameaçadas.

\subsection{Metodologia}

Um plano de manejo é um projeto dinâmico que determina o zoneamento de uma unidade de conservação (IBAMA, 2009). A região de Cananéia é constituída por um mosaico de áreas protegidas abrangendo várias Áreas de Proteção Ambiental (APAs) e Estações Ecológicas, sendo declarada pela UNESCO como Reserva da Biosfera em 1991 e inscrita como Patrimônio Mundial Natural em 1999 (UNESCO, 2009; IBAMA, 2009). Toda esta região compõe parte de um corredor migratório para a espécie Chelonia mydas (Caraccio, 2008), que utiliza esta região tanto para alimentação e desenvolvimento, como para abrigo, durante sua fase juvenil (Bondioli, 2008).

Entre estas APAs, destaca-se o Parque Estadual Ilha do Cardoso (PEIC), criado pelo Decreto $n^{\circ} 40.319$ de 03/07/1962, que abrange uma área de 15.100 hectares, onde são encontrados todos os tipos de vegetação da Mata Atlântica costeira (74\% da área total do Parque) que proporcionam uma variedade extraordinária de ambientes e uma alta diversidade biológica. O PEIC integra o Complexo Estuarino Lagunar de IguapeCananéia-Paranaguá, que se estende pelo litoral desde Peruíbe (SP) até Paranaguá (PR) (MAPA). É considerado um dos maiores criadouros de espécies marinhas do Atlântico sul, sendo prioritária a sua conservação (IUCN, 1984).

As praias, os costões rochosos e as dunas podem ser vistos na face da ilha que recebe as águas do oceano e os manguezais se formam no Canal do Ararapira e na Baía de Trapandé, na face ocidental da ilha. Além disso, uma extensa restinga cobre a maior parte da planície litorânea da Ilha.

Existem seis comunidades caiçaras no Parque. Com forte influência cultural indígena, desenvolveram um apurado conhecimento da natureza. São formadas em sua maioria por pescadores que, atualmente, têm o turismo como fonte substancial de renda (Diegues, 2001).

São encontrados numerosos sambaquis (Calippo, 2004), ruínas da ocupação humana a partir do período colonial e um marco do tratado de Tordesilhas, que também indicam a grande importância histórica deste Parque. 
A elaboração do plano de manejo do PEIC teve início em 1997, adotando o modelo de processo participativo no qual as comunidades envolvidas, instituições governamentais e não governamentais que atuam no Parque puderam participar ativamente. Além disto, informações técnico-científicas produzidas foram levantadas e sistematizadas. Em 1998 formalizou-se a primeira fase deste plano de manejo denominada Plano de Gestão Ambiental (PGA, 1998). Sua finalização e aprovação deuse apenas em 2001, através do monitoramento e avaliação da primeira fase (PGA), de discussões realizadas através de oficinas e levantamento de dados primários complementares (Campolim, 2008).

Visando sustentar uma proposta de preservação da população de tartarugas verdes juvenis existentes em Cananéia, propôs-se a implementação do plano de manejo do Parque Estadual Ilha do Cardoso com os dados genéticos e ecológicos, obtidos neste estudo. Pretendeu-se também, contribuir na elaboração de novos planos para proteção de áreas mais extensas desta região com o intuito de mantê-la o mais intacta possível, preservando não somente a grande biodiversidade ali existente, mas também um habitat saudável para estes animais ameaçados de extinção.

\subsection{Resultados}

A partir dos dados obtidos nesta tese (capítulo 2 e 3) reunimos e sintetizamos as informações genéticas e biológicas que apoiassem a necessidade de preservação da região estudada de forma a ser possível anexá-las ao plano de manejo da Ilha do Cardoso a fim de que, além da proibição de caça e coleta destes animais (Portaria ${ }^{\circ}$ n.005/1986 - SUDEPE, válida para todo território brasileiro), esta região fosse considerada como prioritária para a preservação de tartarugas verdes no Brasil.

As informações incluídas foram:

- A caracterização da região como área de alimentação para juvenis de Chelonia mydas, além da comprovação de receber as outras cinco espécies de tartarugas marinhas que ocorrem na costa brasileira (Bondioli, 2008).

- A confirmação da heterogeneidade genética desta região, sendo significativamente distinta de todas as áreas de alimentação e de desova analisadas no Oceano Atlântico e, portanto, a necessidade de sua preservação. 
- A comprovação genética de que a região recebe a visita de tartarugas marinhas provenientes de pelo menos seis áreas de desova distintas, caracterizando assim um estoque misto na região.

- Seus índices de diversidade haplotípica e nucleotídica (0.5393 e 0.002138, respectivamente) são similares àqueles apresentados por áreas de alimentação estudadas no Oceano Atlântico.

- A diferenciação genética encontrada entre as amostras anuais.

- Os dados de captura e recaptura, que indicam a permanência destes animais na região por pelo menos 17 meses, além de indicar que esta região compõe parte do corredor migratório utilizado por estes animais, no Atlântico Sul Ocidental.

- Os registros, embora escassos, de animais adultos na região.

- A presença de animais acometidos por fibropapilomatose, sua permanência e o rápido desenvolvimento da doença, durante a estadia do animal em Cananéia (Bondioli, 2007).

- A conectividade e interligação entre Cananéia e outras áreas de alimentação e desova presentes no Atlântico Sul Ocidental, verificada nas análises “Many-toMany” realizadas.

\subsection{Discussão}

Devido ao modelo adotado para a elaboração do plano de manejo do Parque, que permitiu a participação de todos os envolvidos em atividades desenvolvidas na Ilha do Cardoso (moradores, pescadores, entidades governamentais e não governamentais e pesquisadores), e ao seu processo dinâmico de elaboração e estruturação, que proporciona uma renovação contínua, tornou-se possível a inclusão de novas informações sendo os dados aqui apresentados, aplicados de forma direta a preservação destes animais. Ao passar por atualizações contínuas, este instrumento de proteção fornece subsídios que contribuem, de maneira direta para a preservação das tartarugas verdes na região.

O Complexo Estuarino Lagunar de Iguape-Cananéia-Paranaguá (que inclui a Ilha do Cardoso e Ilha Comprida) provém recursos energéticos para diversas colônias, além de ser utilizado pelos animais, para seu desenvolvimento, como indicam os dados de marcação e recaptura, sendo assim de grande importância na manutenção das 
populações de tartarugas verdes, não apenas em águas brasileiras, mas no Atlântico Sul Ocidental.

De acordo com a classificação proposta por Moritz (1994), esta região poderia ser identificada e tratada como MU (unidade de manejo), uma vez que representa uma unidade populacional que exibe diferenciação genética significante em relação a todas as outras áreas analisadas.

Em relação à diferença encontrada entre as amostras anuais, esta pode indicar uma flutuação na variabilidade genética deste estoque misto e que esta, pode ser ainda maior que a registrada no presente trabalho.

Os dados obtidos através das MSA e MM demonstram que tais regiões apresentam-se profundamente interligadas, dependendo umas das outras para 0 equilíbrio de populações saudáveis necessitando de atenção, visto o grau atual de ameaça que sofre. A importância da incorporação de parâmetros ecológicos durante as análises genéticas e informações biológicas de qualquer outra natureza que contribuam ao entendimento da dinâmica populacional da região são imprescindíveis para que estes dados sejam validados e tenham utilidade e aplicação direta na proteção das tartarugas marinhas.

Todas estas informações serão futuramente aplicadas, do mesmo modo, no plano de manejo da APA de Ilha Comprida, cujo conselho gestor está atualmente sendo formado e para o qual recebemos convite a participar, com o intuito de iniciar a elaboração de seu plano de manejo.

Atividades de educação ambiental nas escolas de primeiro e segundo grau de Cananéia e Ilha Comprida e a conscientização, tanto da comunidade local, como de turistas, que frequentam a região são necessárias e contribuem de maneira positiva provocando alterações positivas no modo como estas pessoas interagem com os recursos naturais com os quais convivem. 


\section{Conclusão Geral}

A região de Cananéia provém recursos energéticos, sob a forma de bancos de algas e angiospermas marinhas para uma população de juvenis de tartarugas verdes que compõe um estoque misto. As Ilhas Ascensão são a principal área de desova, contribuindo com 63\% dos animais amostrados seguido de Ilhas Aves/Suriname que contribuem com $26 \%$. O restante da amostragem é composto por haplótipos raros, em baixas frequências.

As análises de estoque misto provaram ser úteis no entendimento da dinâmica da referida população e o método bayesiano, levando-se em conta o número de fêmeas que compunha cada área de desova contribuinte a priori, produziram os resultados com menores intervalos de confiança e mais próximos a realidade biológica da espécie sendo, portanto, escolhidos para descrever genéticamente esta população. Além disto, o sistema de correntes oceânicas que banha o Complexo Estuarino pode estar envolvido no recrutamento de juvenis para esta área de forrageio merece destaque, tendo a Corrente Norte Equatorial grande papel no recrutamento de filhotes provenientes das Ilhas Ascensão e das colônias africanas para Cananéia.

A longo prazo, prevê-se o monitoramento desta população com o intuito de descobrir se a utilização dos dados aqui descritos foram úteis para a conservação desta região.

Por realizar uma análise baseada em sequências da região controle do DNA mitocondrial de uma população, pretendíamos, além de realizar comparações com outras regiões anteriormente estudadas, acessar informações sobre as linhagens matrilineares que compõem este estoque misto.

Informações obtidas através da literatura, comprovam não haver grande diferença nos resultados ao estudar loci de microssatelites nucleares (Naro-Maciel, 2006). Contudo, pretende-se realizar tais análises com o intuito de conhecer seus resultados e ter um panorama genético completo para esta população. Da mesma forma, as análises descritas neste trabalho terão continuidade a fim de verificar as diferenças anuais continuam sendo registradas com o intuito de procurar entender quais mecanismos são responsáveis por estas diferenças. 


\section{Anexo I}

\section{Artigos completos publicados em periódicos}

Reis, E. C. ; Bondioli, A. C. V. ; Soares, L. S. ; Lôbo-Hadju, G. . Detection of polymorphisms of the mtDNA control region of Caretta caretta (Testudines: Cheloniidae) by PCR-SSCP. Genetics and Molecular Research, v. 8, p. 215222, 2009.

Nagaoka, S. M. ; Bondioli, A. C. V. ; Monteiro-Filho, E. L. A. . Sea Turtle Bycatch By CERCO-FIXO (FENCE FIXED TRAP) in Cananéia Lagoon Estuarine Complex, Southern of São Paulo State, Brazil. Marine Turtle Newsletter, v. 119, p. 4-5, 2008.

Bondioli, A. C. V. ; Nagaoka, S. M. ; Monteiro-Filho, E. L. A. . Chelonia mydas. Habitat and occurrence. Herpetological Review, v. 39, p. 213-213, 2008.

Loreto, B. O. ; Bondioli, A. C. V. . Epibionts associated with green sea turtles (Chelonia mydas) from Cananéia, Southeast Brazill. Marine Turtle Newsletter, v. 122, p. 5-8, 2008.

\section{Textos em jornais de notícias e revistas}

Bondioli, A. C. V. ; Nagaoka, S. M. ; Monteiro-Filho, E. L. A. . De olho nas Tartarugas. Jornal do Brasil, Rio de Janeiro, p. 32 - 32, 07 dez. 2008.

Bahia, N. C. F. ; Bondioli, A. C. V. . A interação das tartarugas marinhas com a pesca sob o olhar caiçara. TV Ecológica, 05 set. 2008.

Bondioli, A. C. V. ; Nagaoka, S. M. ; Monteiro-Filho, E. L. A. . De olho nas Tartarugas. Ciência Hoje, p. 64 - 65. 


\section{Referências Bibliográficas}

\section{Introdução Geral}

DeSalle R, Amato G (2004) The expansion of conservation genetics. Nature Reviews. 5:702-711.

Frakham R, Ballou JD \& Briscoe DA (2004) A primer to conservation genetics. Cambridge UK, Cambridge University Press, 220p.

Formia (2002) Population and genetic structure of the green turtle (Chelonia mydas) in west and central Africa; implications for management and conservation. Thesis for Doctor of Philosophy. Cardiff University.

IUCN 2008. 2008 IUCN Red List of Threatened Species. <www.iucnredlist.org>. Downloaded on 06 March 2009.

Lahanas PN, Bjorndal KA, Bolten AB et al. (1998) Genetic composition of a green turtle (Chelonia mydas) feeding ground population: evidence for multiple origins. Marine Biology, 130, 345-352.

Moritz C (2002) Strategies to Protected Biological diversity and evolutionary process that sustain it. Systematic Biological 51:238-254.

Papi F, Luschi P, Akesson S, Capogrossi S, Hays GC (2000) Open-sea migration of magnetically disturbed sea turtles. The Journal of Experimental Biology 203, 3435-3443.

Pimm SL, Brooks TM (2000) The sixth extinction: how large, where and when? Nature and Human Society. National Research Concil.

Wilson EO (1997) Biodiversidade. Nova Fronteira S. A., Rio de Janeiro, Brasil, 658p.

\section{Capítulo I}

Adnyana W, Ladds P W, Blair D (1997) Observation of fibropapillomatosis in green turtle Chelonia mydas in Indonesia. Australian Veterinary Journal 75:737-742.

Aguirre A A (1998) Fibropapillomas in Marine Turtles: A Workshop at the 18th Annual Symposium on Biology and Conservation of Sea Turtles. Marine Turtle Newsletter 82:10-12.

Allard M, Miyamoto M M, Bjourndal K A, Bolten A B, Bowen B W, (1994) Support for natal homing in green turtles from mitochondrial DNA sequences. Copeia 94:34-41 
Arthur K E, Balasz G H (2008) A comparison of immature green turtle Chelonia mydas diets in seven sites in the main Hawaiian Islands. Pacific Science 62(2):205-217.

Avens L, Braun-McNeill, Epperly S, Lohmann (2003) Site fidelity and homing behaviour in juvenile loggerhead sea turtle Caretta caretta. Marine Biology 143:211-220.

Avise JC, Bowen BW, Lamb T, Meylan AB \& Bermingham E (1992) Mitochondrial DNA evolution at turtle’s pace: evidence for low genetic variability and reduced microevolutionary rate in the Testudines. Molecular Biology and Evolution 9: 457-473.

Balazs (2000) Factors to consider in the tagging of sea turtles. In: Técnicas de Investigación y Manejo para la Conservación de las Tortugas Marinas. IUCN/SSC Marine Turtle Specialist Group Publication $n^{\circ} 4$.

Bass AL, Witzell WN (2000) Demographic composition of immature green turtles (Chelonia mydas) from the east central Florida coast: evidence from mtDNA markers. Herpetologica 56: 357-367.

Bass AL, Epperly SP, Braun-McNeill J (2006) Green turtle (Chelonia mydas) foraging and aggregation in the Caribbean and Atlantic: impact of currents and behaviour on dispersal. Journal of Heredity 97: 346-354.

Bickham JW (1981) Two-hundred-milion-year-old-chromossomes: deceleration of the rate of the karyotypic evolution in turtles Science 212:1291-1293.

Bjorndal K A, Bolten A B, Lagueux C J (1994) Ingestion of marine debris by juvenile sea turtles in coastal Florida habitats. Marine pollution bulletin 28:154-158.

Bjorndal K A (1997) Foraging Ecology and Nutrition of Sea Turtles. In: The Biology of Sea Turtles (ed Peter L Lutz \& John A Musick). CRC Press, 432p.

Bjorndal K A (2000) Prioridades para la investigación en habitats de alimentación. In: Técnicas de Investigación y Manejo para la Conservacion de Las Tortugas Marinas. Grupo Especialista en Tortugas Marinas IUCN/CSE.

Bjorndal KA, Bolten A B, Moreira L, Bellini C, Marcovaldi M A (2006) Population structure and diversity of Brazilian green turtle rookeries based on mitochondrial DNA sequences. Chelonian Conservation and Biology 5(2):262-268.

Bolten, AB and Balazs GH (1995) Biology of the early pelagic stage-the "'lost year.'” In: Biology and conservation of sea turtles, revised edition. Smithsonian Institution Press, Washington, D.C., USA. 
Bolten AB, Bjorndal KA, Martins HR, Dellinger T, Biscoito MJ, Encalada SE, Bowen BW (1998) Transatlantic developmental of loggerhead sea turtle demonstrated by mtDNA sequence analysis. Ecological Applications 8(1):1-7.

Bonhomme F, Salvidio S, LeBeau A, Pasteur G (1987) Comparaison genetique des tortues vertes (Chelonia mydas) des Oceans Atlantique, Indien et Paficique: une illustration apparente de la theorie mullerienne classique de la estructure genetique des populations? Genetica 74:89-94.

Bouchard S S, Bjorndal K A (2000) Sea turtle as biological transporters of nutrientsand energy from marine to terrestrial ecosystems. Ecology 81(8):2305-2313.

Bourjea J, Lapegue S, Gagnevin L et al. (2007) Phylogeography of the green turtle, Chelonia mydas, in the Southwest Indian Ocean. Molecular Ecology, 16, 175186.

Bowen BW, Meylan AB, Ross P, Limpus CJ, Balazs GH, Avise JC (1992) Global population structure and natural history of green turtle (Chelonia mydas) in terms of matriarchal phylogeny. Evolution 46: 865-881.

Bowen BW, Nelson WS, Avise JC (1993) A molecular phylogeny of marine turtles: Trait mapping, rate assessment and conservation relevance. Proceedings of National Academy of Science USA 90:5574-5577.

Bowen BW, Kamezaki N, Limpus CJ, Hughes GH, Meylan AB, Avise JC (1994) global phylogeography of the loggerhead turtle (Caretta caretta) as indicated by mitochondrial DNA haplotypes. Evolution, 48, 1820-1828.

Bowen BW, Abreu-Grobois FA, Balazs GH, Kamekasi N, Limpus CJ, Ferl RJ (1995) Trans-pacific migrations of the loggerhead turtle (Caretta caretta) demonstrated with mitochondrial DNA markers. Proceedings of Natioanl Academy of Science USA 92: 3731-3734.

Bowen BW, Karl SA (1997) Population genetics, phylogeography, and molecular evolution. In: Lutz, P L, and Musick, J A. The Biology of sea turtles. Boca Raton: CRC Press, pp. 29-50.

Bowen, B. W., A.M. Clark, F.A. Abreu-Grobois, A. Chaves, H.A. Reichart, and R.J. Ferl. 1998. Global phylogeography of the ridley sea turtles (Lepidochelys spp.) as inferred from mitochondrial DNA sequences. Genetica 101 (3): 179-189.

Bowen BW, Nelson WS, Avise JC (2003) A molecular phylogeny for marine turtles: Trait mapping, rate assessement and conservation relevance. Proceedings of National Academy of Science 90:5574-5577. 
Bowen BW, Bass AL, Chow S-M et al. (2004) Natal homing in juvenile loggerhead turtles (Caretta caretta) Molecular Ecology, 13:3797-3808.

Bowen BW, Bass AL, Soares L, Toonen RJ (2005) Conservation implications of complex population structure: lessons from the loggerhead turtle (Caretta caretta). Molecular Ecology, 14, 2389-2402.

Bowen BW \& Karl SA (2007) Population genetics and phylogeography of sea turtles. Molecular Ecology 16:4907-4986.

Boyle M C, Limpus C J (2008) The stomach contents of post-hatchling green and loggerhead sea turtles in the southwest Pacific: an insight into habitat association. Marine Biology 155:233-241.

Broderick D, Moritz C, Miller JD, Guinea M, Prince RJ, Limpus CJ (1994) Genetic studies of the hawksbill turtle: evidence for multiple stocks and mixed feeding grounds in Australian waters. Pacific Conservation Biology, 1, 123-131.

Bugoni L, Krause L, Petry MV (2001) Marine Debris and Human Impacts on Sea Turles in Souther Brazil. Marine Pollution Bulletin 44:1330-1334.

Campbell LM (2003) Contemporary Culture, Use, and Conservation of Sea Turtles. In: The Biology of Sea Turtles vol II (ed Peter L Lutz, John A Musick \& J Wykenen). CRC Press, 455 p.

Carr A, Hirth H (1967) Social facilitation in green turtles siblings. Animal Behaviour 9: 68.

Carr, A, Carr MH, Meylan AB (1978) The ecology and migrations of sea turtles, 7. The west Caribbean green turtle colony. La ecología y migraciones de tortugas marinas, 7. La colonia de la tortuga verde del Caribe occidental. Bulletin of the American Museum of Natural History 162:1-46.

Carr A (1986) Rips, Fads and little loggerheads. BioScience 36:92-100.

Carr A (1987) News perspectives on the pelagic stage of sea turtle development. Conservation Biology 1:103-120.

Conceição MB, Cornejo DO, Felger RS (1990) Electrophoretic characterization of a hybrid between Eretmochelys imbricata and Caretta caretta (Chelonidae). Comparative Biochemistry and Physiology, 97:275-278.

Crowder LB, Hopkins-Murphy SB, Royle JA (1995) Effects of turtle excluder devices (TEDs) on loggerhead sea turtle populations. Copeia 7:773-779.

Derraik JGB (2002) The pollution of marine environment by plastic debris: a review. Marine Pollution Bulletin 44:842-852. 
Dethmers KEM, Broderick D, Moritz C et al. (2006) The genetic structure of Australasian green turtles (Chelonia mydas): exploring the geographical scale of genetic exchange. Molecular Ecology, 15, 3931-3946.

Díaz-Fernández R, Okayama T, Uchiyama T (1999) Genetic sourcing for the hawksbill turtle, Eretmochelys imbricata, in the northern Caribbean region. Chelonian Conservation and Biology, 3, 298-300.

Dutton, PH, Davis SK, Guerra T,Owens D (1996) Molecular Phylogeny for Marine Turtles based on Sequences of the ND4-Leucine tRNA and Control Regions of Mitochondrial DNA. Molecular Phylogeny and Evolution. 5 (3): 511-521.

Dutton, PH, Bowen BW, Owens DW, Barragan A, Davis SK (1999) Global phylogeography of the leatherback turtle Dermochelys coriacea. Journal of Zoology, London 248:397-409.

Dutton PH, Hitipeuw C, Zein M (2007) Status and genetic structure of nesting stocks of leatherback turtles (Dermochelys coriacea) in the western Pacific. Chelonian Conservation and Biology, 6, 47-53.

Dutton, PH, Balazs, GH, LeRoux RA, Murakawa SKK, Zarate P, Martinez LS (2008) Composition of Hawaiian green turtle foraging ground aggregations: mtDNA evidence for a distinct regional population. Endangered Species Research 5:3744.

Encalada S E, Lahanas P N, Bjorndal K A, Bolten A B, Miyamoto MM, Bowens B W, (1996) Phylogeography and population structure of the Atlantic and Mediterranean green turtle Chelonia mydas: a mitochondrial DNA control region sequence assessment. Molecular Ecology. 5: 473-483.

Ernest CH, Barbour RW (1989) Turtles of the World. Washington, D.C. Smithsonian Institution Press, 313p.

Ferreira R.L., Santos M.R., Martins H.R., Bolten A.B., Isidro E., Giga A. and Bjorndal K.A. (2003) Accidental captures of loggerhead sea turtles by the Azores longline fishery in relation to target species and gear retrieving time. In Proceedings of the Twenty-Second Annual Symposium on Sea Turtle Biology and Conservation NOAATechnicalMemorandumNMFS-SEFSC503, 261-262.

Fitzsmmons NN, Moritz C, Moore SS (1995) Conservation and dynamics of Microssatelites Loci over 300 million years of Marine Turtle Evolution. Molecular Biology and Evolution 12(3):432-440. 
FitzSimmons NN, Moritz C, Limpus CJ, Pope L, Prince R (1997) Geographic structure of mitochondrial and nuclear gene polymorphisms in Australian green turtle populations and male-biased gene flow. Genetics, 147, 1843-1854.

Fitzsmmons NN (1998) Single paternity of clutches and sperm storage in the promiscuous green turtle (Chelonia mydas) Molecular Ecology 7:575-584.

Foley A M, Schroeder B A, Redlow A E, Fick-Child K, Teas, W G (2005) Fibroppapilomatosis in stranded green turtles Chelonia mydas from the eastern United States (1980-1998): trends and association with environmental factors. Journal of Wildlife Disease 41(1):29-41.

Formia (2002) Population and genetic structure of the green turtle (Chelonia mydas) in west and central Africa; implications for management and conservation. Thesis for Doctor of Philosophy. Cardiff University.

Gaffney ES \& Meylan PA (1988) A Phylogeny of Turtles. In: The phylogeny and classification of tretapods, vol1, Amphibia, Reptilia, Birds, The Systematic Association, Clarendon Press, Oxford.

Gaffney ES (1990) The comparative osteology of The Triassic turtle Proganochelys. Bulletin of American Museum of Natural History 194:1-263.

Galbraith, DA (1993) Multiple paternity and sperm storage in turtles. Herpetological Journal 3:117-123.

Garcia-Porta J \& Casanovaso-Vilar I (2001) The origin and the first evolutionary stages of turtles: new perspectives. The European Herpetology Magazine 19:47-51.

Gerosa G. and Casale P. (1999) Interaction of marine turtles with fisheries in the Mediterranean. Tunis, Tunisia: UNEP, Regional Activity Centre for Specially Protected Areas (RAC/SPA).

Greenblatt R J, Work T M, Dutton P, Sutton C A, Spraker T R, Casey R N, Diez, C E, Parker D, Leger J S, Balazs G H, Casey J W (2005) Journal of Zoo and Wildlife Medicine 36(3):527-530.

Guebert FM (2008) Ecologia alimentar e consumo de material inorgânico por tartarugas verdes, Chelonia mydas, no litoral do estado do Paraná. Tese de mestrado. Universidade Federal do Paraná.

Harless M \& Morlock H (1979) Turtles. Perspective and Reseach. John Wiley and Sons. New York. 
Hatase H, Kinoshita M, Bando T et al. (2002) Population structure of loggerhead turtles, Caretta caretta, nesting in Japan: bottlenecks on the Pacific population. Marine Biology 141: 299-305.

Hazel J, Lawler I R, Marsh H, Robson S (2007) Vessel speed collision risk for the green turtle Chelonia mydas. Endangered Species Research 3:105-113.

Hendrickson, JR (1958) The green sea turtle, Chelonia mydas (Linn.) in Malaya and Sarawak. Proceedings of the Zoological Society London 30 (4): 455-535.

Heppel SS, Snover ML, Crowder LB (2003) Sea Turtle Population Ecology. In: The Biology of Sea Turtles vol.2 (ed Peter L Lutz \& John A Musick). CRC Press.

Hirayama, R (1994) Phylogenetic systematics of chelonioid sea turtles. Island Arc 3: 270-284.

Hirayama R (1998) Oldest known Sea Turtle. Nature 392:705-708.

Hoekert WEJ, Neuféglise H, Schouten AD, Menken SBJ (2002) Multiple paternity and female-biased mutation at a microsatellite locus in the olive ridley sea turtle (Lepidochelys olivacea). Heredity, 89:107-113.

Karl SA, Bowen BW, Avise JC (1992) Global population structure and male-mediated gene flow in the green turtle (Chelonia mydas): RFLP analysis of anonymous nuclear DNA regions. Genetics 131:163-173.

Karl SA, Bowen BW, Avise JC (1995) Hybridization among the ancient mariners: identification and characterization of marine turtle hybrids with molecular genetic assays. Journal of Heredity 86:262-268.

Kear BP \& Lee MSY (2006) A primitive protostegidae from Australia and early sea turtle evolution. Biology Letters 2:116-119.

Ireland JS, Broderick AC, Glen F et al. (2003) Multiple paternity assessed using microsatellite markers, in green turtle Chelonia mydas (Linnaeus, 1758) of Ascension Island, South Atlantic. Journal of Experimental Marine Biology and Ecology, 291:149-160.

IUCN (2008) 2008 IUCN Red List of Threatened Species. <www.iucnredlist.org>. Downloaded on 17 February 2009.

James MC, Martin K, Dutton PH (2004) Hybridization between a green turtle, Chelonia mydas, and a loggerhead turtle, Caretta caretta, and the first record of a green turtle in Atlantic Canada. Canadian Field Naturalist, 118:579-582. 
Jensen MP, Abreu-Grobois FA, Frydenberg J, Loeschcke V (2006) Microsatellites provide insight into contrasting mating patterns in arribada vs. non-arribada olive ridley sea turtle rookeries. Molecular Ecology, 15:2567-2575.

Koch AL, Carr A, Erhenfeld DW (1969) The problem of open-sea navigation: the migration of the green sea turtle to Ascencion Island. Journal of Theoretical Biology 22:163-179.

Lahanas PN, Miyamoto MM, Bjorndal KA \& Bolten AB. 1994. Molecular evolution and population genetics of greater Caribbean green turtles (Chelonia mydas) as inferred from mitochondrial DNA control region sequences. Genetica 94: 57-66.

Lahanas PN, Bjorndal KA, Bolten AB et al. (1998) Genetic composition of a green turtle (Chelonia mydas) feeding ground population: evidence for multiple origins. Marine Biology, 130, 345-352.

Lara-Ruiz P, Lopez GG, Santos FR, Soares LS (2006) Extensive hybridization in hawksbill turtles (Eretmochelys imbricata) nesting in Brazil revealed by mtDNA analyses. Conservation Genetics, 7:773-781.

Lee PLM, Luschi P, Hays GC (2007) Detectigin female precise natal philopatry in green turtle using assignment methods. Molecular Ecology, 16:61-74.

Lewison, R. L., L. B. Crowder and S. Freeman. 2004. Quantifying the effects of fisheries on threatened species: the impact of pelagic longlines on loggerhead and leatherback sea turtles. Ecology Letters 7:221-231.

Li C, Wu XC, Rieppel O, Wang L \& Zhao L (2008) An ancestral turtle from late Triassic of southwestern China. Nature 456:497-501.

Limpus C (1993) The green turtle Chelonia mydas, in Queensland: breeding males in the southern Great Barrier Reef. Wildlife Research 20:513-523.

Lohmann KJ, Salmon M, Wykenen J (1990) Funtional autonomy of land and sea orientation systems in hatchlings. Biological Bulletin 179:21-218.

Lohmann KJ, Witherington BE, Lohmann CMF, Salmon M (1997) Orientation, Navigation and Natal Beach Homing in Sea Turtle. In: The Biology of Sea Turtles (ed Peter L Lutz \& John A Musick). CRC Press, 432p.

Lohmann, KJ, Cain, SD, Dodge, SA, Lohmann CMF (2001) Regional magnetic fields as navigational markers for sea turtles. Science. 294: 364-366.

Lorne JK, Salmon M (2007) Effects of exposure to artifical lighting on orientation of hatchling sea turtles on the beach and in the ocean. Endangered Species Research. 3:23-30. 
Lopez-Castro MC, Rocha-Olivares A (2005) The panmixia paradigm of the eastern Pacific olive ridley turtles revised: consequences for their conservation and evolutionary biology. Molecular Ecology 14:3325-3334.

Luke K, Horrocks JA, Leroux RA, Dutton PH (2004) Origins of green turtle (Chelonia mydas) feeding aggregations around Barbados, West Indies. Marine Biology, 144, 799-805.

Luschi P, Hays G C, PAPI F (2003) A review of long-distance movements by marine turtles, and the possible role of ocean currents. Oikos 103:293-302

Lutcavage ME \& Lutz PL (1997) Diving Physiology. In: The Biology of Sea Turtles (ed Peter L Lutz \& John A Musick). CRC Press, 432p.

Lutz PL (1997) Salt, Water and pH Balance in Sea turtles. In: The Biology of Sea Turtles (ed Peter L Lutz \& John A Musick). CRC Press, 432p.

Meylan, AB, Bowen BW, Avise JC (1990) A genetic test of the natal homing versus social facilitation models for green turtle migration. Science 248 (4956):724727.

Meylan AB \& Meylan PA (2000) Introducción a la Evolución, Historias de Vida y Biología de las Tortugas Marinas. In: Técnicas de Investigación y Manejo para la Conservación de las Tortugas Marinas. IUCN/SSC Marine Turtle Specialist Group Publication $\mathrm{n}^{\circ} 4$.

Miller JD (1997) Reprodution in sea turtles. In: The Biology of Sea Turtles (ed Peter L Lutz \& John A Musick). CRC Press, 432p.

Moore MK, Ball RM (2002) Multiple paternity in loggerhead turtle (Caretta caretta) nests on Melbourne Beach, Florida: a microsatellite analysis. Molecular Ecology, 11:281-288.

Moore MK, Bemiss JA, Rice SM, Quattro JM, Woodley CM (2003) Use of restriction fragment length polymorphisms to identify sea turtle eggs and cooked meats to species. Conservation Genetics 4:95-103.

Morreale SJ, Ruiz GJ, Spotila JR, Standora EA (1982) Temperature-dependent sex determination: current practices threaten conservation of sea turtles. Science 216:1245-1247.

Mortimer JA (1995) Factors influencing beach selection by nesting sea turtles. In: Biology and Conservation of Sea Turtles. Smithsonian Institution. 
Mortimer JA (1995) Factors influencing beach selection by nesting sea turtle In: Biology and conservation of sea turtles, revised edition. Smithsonian Institution Press, Washington, D.C., USA.

Musick JA \& Limpus CJ (1997) Habitat Utilization and Migration in Juveniles Sea Turtles. In: The Biology of Sea Turtles (ed Peter L Lutz \& John A Musick). CRC Press, 432p.

National Research Concil (1990) Decline of Sea Turtles: causes and prevention. National Research Concil, Washington, DC.

Naro-Maciel E (2005) Connectivity and Structure of Atlantic Green Sea Turtle (Chelonia mydas): A Genetic Perspective. PhD Dissertation, Columbia University, USA, 182pp.

Naro-Maciel E, Le M, Fitzsimmons NN, Amato G (2008) Evolutionary relationship of marine turtles: A molecular phylogeny based on nuclear and mitochondrial genes. Molecular Phylogenetics and Evolution 49:659-662.

Ney, M (1975) Molecular population genetics and evolution. Frontiers of Biology, vol 40. North-Holland Publishing Company, Inc. - New York, 288p.

Norman JA, Moritz C, Limpus CJ (1994) Mitochondrial DNA control region polymorphisms: genetic markers for ecological studies of sea turtles. Molecular Ecology 3:363-3373.

Oravetz, C.A., 1999. Reducing incidental catch in fisheries. In: Eckert, K.L., Bjorndal, K.A., Abreu-Grobois, F.A., Donnelly, M. (Eds.), Research and Management Techniques for the Conservation of Sea Turtles. IUCN/SSC Marine Turtle Specialist Group Publication No. 4.

Parham JF \& Zug GR (1996) Chelonia agassizii - valid or not? Marine Turtle Newsletter. 72:2-5.

Pearse DE \& Avise JC (2001) Turtle Mating System: Behaviour, Sperm Storage and Genetic Paternity. The American Genetic Association 92:206-211.

Plotkin P (2003) Adult migration and habitat uses. In: The Biology of Sea Turtles vol.2 (ed Peter L Lutz \& John A Musick). CRC Press.

Pritchard PCH, Mortimer JA (2000) Taxonomy, External Morphology and Species Identification. In: Técnicas de Investigación y Manejo para la Conservación de las Tortugas Marinas. IUCN/SSC Marine Turtle Specialist Group Publication $n^{\circ} 4$. 
Pritchard PCH (1997) Evolution, Phylogeny and Current Status. In: The Biology of Sea Turtles (ed Peter L Lutz \& John A Musick). CRC Press, 432p.

Reich KJ, Bjorndal KA, Bolten AB (2007) The “lost year” of green turtles: using stable isotopes to study cryptic lifestage. Biology Letters 3: 712-714.

Revelles M, Cardona L, Aguilar A, Fernandez G (2007) The diet of pelagic loggerhead sea turtles (Caretta caretta) of the Balearic archipelago (Western Mediterranean): relevance of long-line baits. Journal of the Marine Biological Association of the United Kingdom 87: 805-813.

Robert AM, Gabriel G, Robinson J (1999) Dying to heal: The use of animals in traditional medicine. Animals Agenda 19:30-31.

Roberts MA, Schwartz TS, Karl SA (2004) Global population structure and malemediated gene flow in the green sea turtle (Chelonia mydas): analysis of microsatellite loci. Genetics, 166, 1857-1870.

Roman J, Bowen BW (2000) The mock turtle syndrome: genetic identification of turtle meat purchased in the south-eastern United States of America. Animal Conservation 3: 61-65.

Ruxton GD, Speed MP, Kelly DJ (2004) What, if anything, is adaptative function of countershading? Animal Behaviour 68:445-451.

Sales G, Giffoni BB, Barata PCR (2008) Incidental catch of sea turtles by brazilian pelagic longline fisheries. Journal of the Marine Biological Association of the United Kigdom 88:853-864.

Santoro M, Moreale J A, Stacy B, Greiner E C (2007) Rameshwaretrona uterocrescens trematode parasitismof the oesophageal glands in green turtles Chelonia mydas. Veterinary Record 106:59-60.

Sasso CR, Epperly SP (2006) Seasonal Sea Turtle mortality risk from forced submergence in bottom trawls. Fisheries Research 81:86-88.

Sears CJ, Bowen BW, Chapman RW, Galloway SB, Hopkins-Murphy SR, Woodley CM (1995) Demographic composition of the feeding population of juveniles loggerhead sea turtles (Caretta caretta) of Charleston South Carolina:evidence from mitochondrial DNA markers. Marine Biology 123:869-874.

Seminoff JA, Crouse D, Abreu-Grobois FA (2002) 2002 Red List Status Assessment Green Turtle (Chelonia mydas) Marine Turtle Specialist Group.

Seminoff JA, Karl SA, Schwartz T, Resendiz A (2003) Hybridization of the green turtle (Chelonia mydas) and the hawksbill turtle (Eretmochelys imbricata) in the 
Pacific Ocean: indications of an absence of gender bias in the directionality of crosses. Bulletin of Marine Science 73:643-652.

Schroth W, Streit B, Schierwater B (1996) Evolutionary handicap for turtles. Nature, 384, 521-522.

Shanker K, Ramadevi J, Choudhury BC, Singh L, Aggarwal RK (2004) Phylogeography of the olive ridley turtles (Lepidochelys olivacea) on the East coast of India: implications for conservation theory. Molecular Ecology 13, 1899-1909.

Silva EP, Russo CAM (2000) Techniques and statistical data analysis in molecular population genetics. Hydrobiologia 420:119-135.

Standora EA, Spotila JR. 1985. Temperature-dependent sex determination in sea turtles. Copeia 1985:711-722.

Taberlet, P (1996) The use of the mitochindrial DNA control region sequencing in conservation genetics. In: Molecular Genetic Approaches in Conservation. Oxford Express University, New York.

Swimmer Y, Sales G, Giffoni B and Thome' JC (2006) Sea turtles and longline fisheries interactions in Brazil—an update on field trials and post-release mortality and movements. In Frick M. et al. (eds) Books of Abstracts of the Twenty-sixty Annual Symposium on Sea Turtle Biology and Conservation. Athens, Greece: International Sea Turtle Society, pp. 267-268.

Weishampell JF, Bagley DA, Ehrhart LM (2004) Earlier nesting by loggerhead sea turtles following sea surface warming. Global Change Biology 10: 1424-1427

Werneck, M R. Helmintofauna de Chelonia mydas necropsiadas na base do projeto Tamar. 2007. 50f. Dissertação (Mestrado em Biologia e Ciências Aplicadas) Universidade Estadual Paulista, Instituto de Biociências, Botucatu, 2007.

Williams, E. H., Jr., and L. Bunkley-Williams. 1996. Fibropapillomas in Hawaiian sea turtles. Bishop Mus. Occas. Pap. 46:46-49.

Willians E H Jr, Bunkley-Willians L (2006) Early fibropapillomas in Hawaii and Occurrence in all sea turtle species: the panzootic, associated leeches wideranging on sea turtles, and species of study leeches should be identified. Journal of Virology 80(9):4643-4644.

Wykenen J (1997) Sea Turtle Locomotion: Mechanics, Behaviour and Energetics. In: The Biology of Sea Turtles (ed Peter L Lutz \& John A Musick). CRC Press, 432p. 
Wykenen J (2001) The Anatomy of Sea Turtle. NOAA Technical Memorandum NMFSSEFSC-470, 172p.

Velez-Zuazo X, Ramos WD, Van Dam RP, Diez CE, Abreu-Grobois A, McMillan O (2008) Dispersal, recruitment and migratory behaviour in a hawksbill sea turtle aggregation. Molecular Ecology 17:839-853.

Zardoya R, Meyer A (2001) The evolutionary position of turtles revised. Naturwissenschaften 88:193-200.

Zbinden JA, Largaider C, Leippert F, Margaritoulis D, Arlettaz R (2007) High frequency of multiple paternity in the largest rookerie of Mediterranean loggerhead sea turtles. Molecular Ecology 16:3703-3711.

\section{Capítulo II}

Avise JC, Bowen BW, Lamb T, Meylan AB, Bermingham E (1992) Mitochindrial DNA Evolution at a turtle's paces: evidence for low genetic variability and reduced microevolutionary rates in the Testudines. Molecular Biology and Evolution 9:457-463.

Avise JC (1995) Mitochondrial DNA polymorphism and a connection between genetics and demography of relevance to conservation. Conservation Biology 9: 686-690.

Balazs (2000) Factors to consider in the tagging of sea turtles. In: Técnicas de Investigación y Manejo para la Conservación de las Tortugas Marinas. IUCN/SSC Marine Turtle Specialist Group Publication $n^{\circ} 4$.

Bass AL, LaGueux CJ, Bowen BW (1998) Origin of green turtles, Chelonia mydas, at 'sleeping rocks’ off the northeast coast of Nicaragua. Copeia, 1998, 1064-1069.

Bass AL, Witzell WN (2000) Demographic composition of immature green turtles (Chelonia mydas) from the east central Florida coast: evidence from mtDNA markers. Herpetologica 56: 357-367.

Bass AL, Epperly SP, Braun-McNeill J (2004) Multi-year analysis of stock composition of a loggerhead turtle (Caretta caretta) foraging habitat using maximum likelihood and Bayesian methods. Conservation Genetics, 5, 783-796.

Bass AL, Epperly SP, Braun-McNeill J (2006) Green turtle (Chelonia mydas) foraging and aggregation in the Caribbean and Atlantic: impact of currents and behaviour on dispersal. Journal of Heredity 97: 346-354.

Besnard W (1950) Considerações gerais em torno da região lagunar de Cananéia e Iguape. Boletim do Instituto Paulista de Oceanografia, São Paulo, 1, 9-26. 
Bjorndal KA (2000) Prioridades para la investigación en hábitats de alimentación. In: Técnicas de Investigación y Manejo para la Conservación de las Tortugas Marinas. IUCN/SSC Marine Turtle Specialist Group Publication nº4.

Bjorndal KA, Bolten AB, Moreira L, Bellini C, Marcovaldi MM (2006) Population structure and diversity of Brazilian green turtle rookeries based on mitochondrial DNA sequences. Chelonian Conservation and Biology, 5, 262-268.

Bjorndal KA, Bolten AB (2008) Annual variation in source contribution to a mixed stock: implications for quantifying connectivity. Molecular Ecology 17:21852193.

Bondioli ACV, Nagaoka S M, Loreto BO, Bahia NCF (2007) Registros de Ocorrência de fibropapilomatose e estudos de caso de juvenis de Chelonia mydas na região de Cananéia, sudeste do Brasil. In: III Jornadas de Conservación e Investigación de Tortugas Marinas en el Atlántico Sur Occidental, 2007, Piriápolis, 46-47.

Bondioli ACV, Nagaoka SM, Monteiro-Filho ELA (2008) Chelonia mydas. Habitat and occurrence. Herpetological Review, v. 39, p. 213-213, 2008.

Bowen BW, Karl SA (1997) Population genetics, phylogeography, and molecular evolution. In: Lutz, P L, and Musick, J A. The Biology of sea turtles. Boca Raton: CRC Press, pp. 29-50.

Bowen BW, Bass AL, Soares L, Toonen RJ (2005) Conservation implications of complex population structure: lessons from the loggerhead turtle (Caretta caretta). Molecular Ecology, 14, 2389-2402.

Broderick D, Moritz C (1998) Considerations for mixed stock analysis using mtDNA markers. In: Proceedings of the seventeenth annual sea turtle symposium. Tech. Memo, 162p.

Broderick AC, Fraunstein R, Glen F, Hays GC, Jackson AL, Pelembe T, Ruxton GD, Godley BJ (2006) Are green turtles globally endangered? Global Ecology and Biogeography, 15:21-26.

Brown WM, Prager EM, Wang A, Wilson AC (1982) Mitochondrial DNA sequences of primates: tempo and mode of evolution. Journal of Molecular Evolution, 18, 1432-1432.

Carr, A, Carr MH, Meylan AB (1978) The ecology and migrations of sea turtles, 7. The west Caribbean green turtle colony. La ecología y migraciones de tortugas marinas, 7. La colonia de la tortuga verde del Caribe occidental. Bulletin of the American Museum of Natural History 162:1-46. 
Caraccio MN (2008) Análisis de la composición genética de Chelonia mydas (tortuga verde) en el área de alimentación y desarrollo de Uruguay. Tesis de Maestria. Universidad de la Republica del Uruguay, Montevideo, UY. 89p.

Clement M, Posada D, Crandall K A (2000) TCS: a computer program to estimate gene genealogies. Molecular Ecology 9 (10): 1657-1660.

Diegues AC (1987) Conservação e desenvolvimento sustentado de ecossistemas litorâneos no Brasil. Secretaria Estadual do Meio Ambiente de São Paulo, SP.

Dutton P, Balazs, G H., 1995. Simple Biopsy Technique for Sampling Skin for DNA Analysis of Sea Turtle. Marine Turtle Newsletter 69:9-10.

Dutton, PH, Balazs, GH, LeRoux RA, Murakawa SKK, Zarate P, Martinez LS (2008) Composition of Hawaiian green turtle foraging ground aggregations: mtDNA evidence for a distinct regional population. Endangered Species Research 5:3744.

Encalada S E, Lahanas P N, Bjorndal K A, Bolten A B, Miyamoto MM, Bowens B W, (1996) Phylogeography and population structure of the Atlantic and Mediterranean green turtle Chelonia mydas: a mitochondrial DNA control region sequence assessment. Molecular Ecology. 5: 473-483.

Excoffier L, Smouse PE, Quattro JM (1992) Analysis of molecular variance inferred from metric distance among DNA haplotypes: applications to human mitochondrial DNA restriction data. Genetics, 131: 479-481.

Excoffier, LG, Laval, Schneider S (2005) Arlequin ver. 3.0: An integrated software package for population genetics data analysis. Evolutionary Bioinformatics Online 1:47-50.

Formia A (2002) Population and genetic structure of the green turtle (Chelonia mydas) in west and central Africa; implications for management and conservation. Thesis for Doctor of Philosophy. Cardiff University.

Formia A, Godley BJ, Dontaine JF, Bruford MW (2006) Mitochondrial DNA diversity and phylogeography of endangered green turtle (Chelonia mydas) populations in Africa. Conservation Genetics, 7:353-369.

Formia A, Brodeick AC, Glen F, Godley BJ, Hays GC, Bruford MW (2007) Genetic composition of the Ascension Island green turtle rookerie based on mitochondrial DNA: implications for sampling and diversity. Endangered Species Research 3: 145-158. 
Gelman A, Rubin DB (1992) Inference from iterative simulation using multiple sequences. Statistical Science 7:457-311.

Godley BJ, Richardson S, Broderick AC, Coyne MS, Glen F, Hays GC (2002) Longterm satellite telemetry of the movements and habitat utilisation by green turtles in the Mediterranean. Ecography, 25, p. 352-362.

Guebert FM (2008) Ecologia alimentar e consumo de material inorgânico por tartarugas verdes, Chelonia mydas, no litoral do estado do Paraná. Tese de mestrado. Universidade Federal do Paraná.

IUCN (1984) Threatened protected area of the world. IUCN Comission on National Parks and protected areas, Gland. Suiça.

Hatase H, Kinoshita M, Bando T et al. (2002) Population structure of loggerhead turtles, Caretta caretta, nesting in Japan: bottlenecks on the Pacific population. Marine Biology 141: 299-305.

Hall, TA (2001) BioEdit: a user-friendly biological sequence alignment editor and analysis program for Windows 95/98/NT. Nucl. Acids. Symp. Ser. 41:95-98.

Lahanas PN, Miyamoto MM, Bjorndal KA, Bolten AB (1994) Molecular evolution and population genetics of greater Caribbean green turtles (Chelonia mydas) as inferred from mitochondrial DNA control region sequences. Genetica 94: 57-66.

Lahanas PN, Bjorndal KA, Bolten AB (1998) Genetic composition of a green turtle (Chelonia mydas) feeding ground population: evidence for multiple origins. Marine Biology, 130, 345-352.

Lima EHSM, Lagueux CJ, Castro WD, Marcovaldi MA (1999) From One Feeding Ground to Another: Green Turtle Migration Between Brazil and Nicaragua. Marine Turtle Newsletter 85:10.

Lima EHSM, Troëng S (2001) Link Between Green Turtles Foraging in Brazil and Nesting in Costa Rica? Marine Turtle Newsletter 94:9.

Lima EHSM, Lagueux CJ, Barata PCR, Marcovaldi MA (2003) Second Record of a Green Turtle (Chelonia mydas) Tagged in Brazil and Captured in Nicarágua. Marine Turtle Newsletter 101:27.

Luke K, Horrocks JA, Leroux RA, Dutton PH (2004) Origins of green turtle (Chelonia mydas) feeding aggregations around Barbados, West Indies. Marine Biology, 144, 799-805.

Lum LL, Lima EM, Santos A (1998) Green turtle tagged in Brazil recovered in Trinidad. Marine Turtle Newsletter 82:9. 
Luschi P, Hays GC, Del Seppia C, Marsh R, Papi F (1998) The navigational feats of green sea turtles migrating from Ascension Island investigated by satellite telemetry. The Royal Society, 265:2279-2284.

Lutcavage ME, Plotkin P, Witherington B, Lutz PL (1997) Human impacts on sea turtle survival. In: Lutz, P L, and Musick, J A. The Biology of sea turtles. Boca Raton: CRC Press, pp. 387-409.

Kimura M (1980) A simple method for estimating evolutionary rate of base substitution thought comparative studies of nucleotide sequences. Journal of Molecular Evolution, 16:111-120.

Maciel NAL (2001) Composição, abundância e distribuição espaço-temporal da ictiofauna do complexo estuarino-lagunar de Cananéia, São Paulo, Brasil. Tese de Doutorado, Instituto Oceanográfico da USP, São Paulo, 252pp.

Mendonça JT, Katsuragawa M (2001) Caracterização da pesca artesanal no complexo estuarino-lagunar de Cananéia-Iguape, Estado de São Paulo, Brasil (1995-1996). Acta Scientiarum, 23:535-547.

Meylan A (1995) Sea turtle migration-evidence from tag returns. In: Bjorndal, KA, editor. Biology and Conservation of Sea Turtles. Revised Edition. Smithsonian Institution Press, Washington, D.C, 91-100.

Monteiro-Filho ELA (2000) Group organization of the dolphin Sotalia fluviatilis guianensis in the estuary of southeastern Brazil. Ciência e Cultura, 52:97-101.

Moritz C (2002) Estrategies to protected biological diversity and the evolutionary processes that sustain it. Systematics Biological, 51:238-254.

Musick JA, Limpus CJ (1997) Habitat utilization and migration in juvenile sea turtles. In: Lutz, P L, and Musick, J A. The Biology of sea turtles. Boca Raton: CRC Press, pp137-164.

Nagaoka SM, Bondioli, ACV, Monteiro-Filho ELA (2008) Sea Turtle Bycatch By cerco-fixo (Fence Fixed Trap) in Cananéia Lagoon Estuarine Complex, Southern of São Paulo State, Brazil. Marine Turtle Newsletter, 119:4-5.

Naro-Maciel E, Becker HJ, Lima EHSM, Marcovaldi MA, De Salle R (2007) Testing dispersal hypotheses in foraging green sea turtles (Chelonia mydas) of Brazil. Journal of Heredity, 97, 29-39.

Norman JA, Moritz C, Limpus CJ (1994) Mitochondrial DNA control region polymorphisms: genetic markers for ecological studies of sea turtles. Molecular Ecology 3:363-3373. 
Occhipinti AG (1963) Climatologia Dinâmica do Litoral sul Brasileiro. Contribuições do Instituto Oceanográfico. Série Oceanografia Física, 3:1-86.

O’Corry-Crowe GM, Suydam RS, Rosenberg A, Frost KJ, Dizon AE (1997) Phylogeography, population structure and dispersion patterns of the beluga whale Delphinapterus leucas in the western Neartic revealed by mitochondrial DNA. Molecular Ecology 6:955-970.

Oliveira FC (2007) Etnobotânica da exploração de espécies vegetais para a confecção do cerco-fixo na região do Parque Estadual da Ilha do Cardoso. Tese de Mestrado. Centro de Ciências Biológicas, Universidade Federal de Santa Catarina, Florianópolis, Santa Catarina. 146pp.

Pastene LA, Goto M, Nishiwaki S, Yoshida H, Kanda N (2006) Genetic characteristics and population structure of humpback whales in the Antartic feeding ground as reveleaded by mitochondrial DNA control region sequencing and microsatellite analyses.

Proietti MC, Artico LO, Reisser JW, Maggioni R, Marins LF (2007). Diversidade genética das tartarugas-verdes (Chelonia mydas) da Ilha do Arvoredo, SC: evidências através da análise da região D-loop do DNA mitocondrial. In: XII Congresso Latino-Americano de Ciências do Mar, Florianópolis.

Raymond M, Rousset F (1995) An exact test for population differentiation. Evolution, 49:1280-1283.

Rice WR (1989) Analyzing tables of statistical tests. Evolution, 43:223-225.

Rice MR, Balazs GH (2008) Diving behaviour of the Hawaiian green turtles (Chelonia mydas) during oceanic migrations. Journal of Experimental Marine Biology and Ecology, 356:121-127.

Sambrook KJ, Russel DW, Sambrook J (2001) Molecular Cloning: a laboratory manual. CSHL. New York, USA.

Sanger F, Nichlen S, Coulson AR (1977) DNA sequencing with chain-termination inhibitors. Proceedings of National Academy of Science. USA, 74: 5463 - 5468.

Sato S, Kojima H, Ando J, Ando H, Wilmot RL,Seeb LW, Efremov V, Leclair L, Buchholz W, Jin D-H, Urawa S, Kaeriyama M, Urano A, Abe S (2004) Genetic Population Structure of Chum Salmon in the Pacific Rim Inferred from Mitochondrial DNA Sequence Variation. Environmental Biology of Fishes, 69:37-50. 
Seminoff JA, Zarate P, Coyne M, Foley DG, Parker D, Lyon BN, Dutton PH (2008) Post-nesting migrations of Galápagos green turtles Chelonia mydas in relation to oceanographic conditions: integrating satellite telemetry with remotely sensed ocean data. Endangered Species Research, 4:57-72.

Schneider S, Roessli D, Excoffier L (2000) Arlequin: a software for population genetics data analysis. User manual ver 2000. Genetics and Biometry Lab, Dept. of Anthropology, University of Geneva, Geneva.

Tamar (2008) Protocolo de Marcação e Biometria de Tartarugas Marinhas Projeto Tamar - ICMBio.

Velez-Zuazo X, Ramos WD, Van Dam RP, Diez CE, Abreu-Grobois A, McMillan O (2008) Dispersal, recruitment and migratory behaviour in a hawksbill sea turtle aggregation. Molecular Ecology 17:839-853.

Zaykin, DV,Pudovkin AI (1993). Two programs to estimate significance of chi-square values using pseudo-probability tests. Journal of Heredity 84: 152.

\section{Capítulo III}

Avens L, Lohman KJ (2004) Navigation and seasonal migratory orientation in juvenile sea turtles. Journal of Experimental Biology, 207:1771-1778.

Ayres M, Ayres Junior M, Ayres Dl, Santos AS (2003) BioEstat versão 3.0. Sociedade Civil Mamirauá/MCT - CNPq.

Baker CS, Lento GM, Ciprino F, Palumbi SR (2000) Predicted decline of protected whales based on molecular genetic monitoring of Japanese and Korean Markets. Proceedings of Royal Academy Society of London, 267:1191-1199.

Bass AL (1999) Genetic analysis to elucidated the natural history and behaviour of Hawksbill Turtle (Eretmochelys imbricata) in the wider Caribbean: a review and re-analysis. Chelonian Conservation and Biology, 3:195-199.

Bass AL, Witzell WN (2000) Demographic composition of immature green turtles (Chelonia mydas) from the east central Florida coast: evidence from mtDNA markers. Herpetologica 56: 357-367.

Bass AL, Epperly SP, Braun-McNeill J (2004) Multi-year analysis of stock composition of a loggerhead turtle (Caretta caretta) foraging habitat using maximum likelihood and Bayesian methods. Conservation Genetics 5:783-796. 
Bass AL, Epperly SP, Braun-McNeill J (2006) Green turtle (Chelonia mydas) foraging and nesting aggregations in the Caribbean and Atlantic: impacts of currents and behavior on dispersal. Journal of Heredity 97:346-354.

Bellini C, Marcovaldi MA, Sanchez TM, Grossman A, Sales G (1995) Atol das Rocas Biological Reserve: the second largest Chelonia rookery in Brazil. Marine Turtle Newsletter, 72:1-2.

Bjorndal KA, Bolten AB (2008) Annual variation in source constributions to a mixed stock: implications to quantifying connectivity. Molecular Ecology, 17:21852193.

Bolker B, Okuyama T, Bjorndal K, Bolten A (2003) Sea turtle stock estimation using genetic markers: accounting for sampling error of rare genotypes. Ecological Applications 13:763-775.

Bolker B, Okuyama T, Bjorndal K, Bolten A (2007) Incorporating multiple mixed stocks in mixed stock analysis: 'many-to-many' analyses. Molecular Ecology 16:685-695.

Bouchard SS, Bjorndal KA (2000) Sea turtle as biological transporters of nutrients and energy from marine to terrestrial ecosystem. Ecology, 81:2305-2313.

Bowen BW, Abreu-Grobois FA, Balazs GH, Kamekasi N, Limpus CJ, Ferl RJ (1995) Trans-pacific migrations of the loggerhead turtle (Caretta caretta) demonstrated with mitochondrial DNA markers. Proceedings of National Academy of Science USA 92: 3731-3734.

Bowen BW, Karl SA (1997) Population genetics, phylogeography, and molecular evolution. In: Lutz, P L, and Musick, J A. The Biology of sea turtles. Boca Raton: CRC Press, pp. 29-50.

Bowen BW \& Karl SA (2007) Population genetics and phylogeography of sea turtles. Molecular Ecology 16:4907-4986.

Broderick D, Moritz C (1998) Considerations for mixed stock analysis using mtDNA markers In: Proceedings of the Seventeenth Annual Sea Turtle Symposium. Epperly SP \& Braun J (editors). NOAA Technical Memorandum NMFSSEFSC-415.

Caraccio MN (2008) Análisis de la composición genética de Chelonia mydas (tortuga verde) en el área de alimentación y desarrollo de Uruguay. Tesis de Maestria. Universidad de la Republica del Uruguay, Montevideo, UY. 89p. 
Carr, A, Carr MH, Meylan AB (1978) The ecology and migrations of sea turtles, 7. The west Caribbean green turtle colony. La ecología y migraciones de tortugas marinas, 7. La colonia de la tortuga verde del Caribe occidental. Bulletin of the American Museum of Natural History 162:1-46.

Carreras C, Pont S, Maffucci F, Pascual M, Barceló A, Bentivegna F, Cardona L, Alegre F, SanFélix M, Fernandéz G, Aguilar A (2006) Genetic structuring of immature loggerhead sea turtles (Caretta caretta) in the Mediterranean Sea reflects water circulation patterns. Marine Biology 149:1269-1279.

Catry P, Barbora C, Indjai B, Almeida A, Godley BJ, Vié J-C (2002) First census of the green turtle at Poilão, Bijagós Archipelago, Guinea-Bissau: the most important nesting colony on the Atlantic coast of Africa

Chapman RW (1996) A mixed stock analysis of the greensea turtle: the need for a null hypothesis. US Depart. Commerc., NOAA Tech Memo. NMFS-SESFC, 396:137-146.

Crooks KR, Sanjayan M (2006) Connectivity conservation: maintaining connections for nature. In: Connectivity Conservation, Cambridge University Press, Cambridge, 3-19p.

Excoffier, LG, Laval, Schneider S (2005) Arlequin ver. 3.0: An integrated software package for population genetics data analysis. Evolutionary Bioinformatics Online 1:47-50.

Formia A (2002) Population and genetic structure of the green turtle (Chelonia mydas) in west and central Africa; implications for management and conservation. Thesis for Doctor of Philosophy. Cardiff University.

Gelman, A and Rubin, DB (1992) Inference from iterative simulation using multiple sequences. Statistical Science, 7, 457-511.

Great Circle Distance. GPS Visualizer. Google Earth 4.3.

Grant WS, Milner GB, Krasnowski P, Utter FM (1980) Use of biochemical genetic variants for identification of sockeye salmon (Oncorhynchus nerka) stocks in Cook Inlet, Alaska. Canadian Journal of Fisheries and Aquatic Sciences, 37, 1236-1247.

Hays CG, Akesson S, Broderick AC, Glen F, Godleys BJ, Papi F, Luschi P (2003) Island-findind ability of marine turtles. Proceedings of The Royal Society of London, 270:5-7. 
Hendrickson JR (1980) The ecological strategies of sea turtles. American Zoologist, 20: 597-608.

Lahanas PN, Bjorndal KA, Bolten AB et al. (1998) Genetic composition of a green turtle (Chelonia mydas) feeding ground population: evidence for multiple origins. Marine Biology, 130, 345-352.

Lima EHSM, Lagueux CJ, Castro WD, Marcovaldi MA (1999) From One Feeding Ground to Another: Green Turtle Migration Between Brazil and Nicaragua. Marine Turtle Newsletter 85:10.

Limpus CJ, Miller JD, Parmentes CJ (1992) Migration of a green turtle (Chelonia mydas) and loggerhead (Caretta caretta) turtles to and from Eastern Australian rookeries. Wildlife Research, 19:347-358.

Luke K, Horrocks JA, Leroux RA, Dutton PH (2004) Origins of green turtle (Chelonia mydas) feeding aggregations around Barbados, West Indies. Marine Biology, 144, 799-805.

Lunn DJ, Thomas A, Best N, Spiegelhalter D (2000) WinBUGS -- a Bayesian modelling framework: concepts, structure, and extensibility. Statistics and Computing, 10:325--337.

Luschi P, Hays GC, DelSeppia C, Marsh R, Papi F (1998) The navigational feat of green sea turtle migrating from the Ascencion Island investigated by satellite telemetry. Proceedings of The Royal Society of Academy of London, 265:22792284.

Luschi P, Benhamou S, Girard C, Ciccione S, Roos D, Sudre J, Benvenuti S (2007) Marine Turtle Use Geomagnetic Cues during Open-sea Homing. Current Biology, 17:126-133.

Mardsen JE, Krueger CC, May B (1989) Identification of Parental Origins of Naturally Produced Lake Trout in Lake Ontario: Application of Mixed-Stock Analysis to a Second Generation. North American Journal of Fisheries Management, 9:257268.

Martin TG, Chadès I, Arcese P, Marra PP, Possingham HP (2007) Optimal Conservation of migratory Species. Plos One, 2: 751.

Naro-Maciel E (2006) Connectivity and structure of Atlantic green sea turtles (Chelonia mydas): a genetic perspective. PhD Dissertation, Columbia University, USA. 182pp. 
Naro-Maciel E, Becker HJ, Lima EHSM, Marcovaldi MA, De Salle R (2007) Testing dispersal hypotheses in foraging green sea turtles (Chelonia mydas) of Brazil. Journal of Heredity, 97, 29-39.

Okuyama T, Bolker BM (2005) Combining genetic and ecological data to estimate sea turtle origins. Ecological Applications, 15:315-325.

Pela JJ, Milner GB (1987) Use of genetic marks in stock composition analysis. In: Population Genetics and Fisheries Management. University of Washington Press, Seatle, 247-256.

Pella J, Massuda M (2001) Bayesian Method for analysis of stock mixtures from genetic characters. Fisheries Bulletin, 99:151-167.

Potvin C, Bernatchez L (2001) Lacustrine spatial distribution of landlocked Atlantic salmon populations assessed across generations by multilocus individual assignment and mixed-stock analyses. Molecular Ecology, 10:2378-2388.

R version 2.9.0 (2009) The R Foundation for Statistical Computing.

Reece JS, Ehrhart LM, Parkinson CL (2006) Mixed stock analysis of juvenile loggerheads (Caretta caretta) in Indian River Lagoon, Florida: implications for conservation planning. Conservation Genetics 7:345-352.

Ruzzante DE, Taggart CT, Lang S, Cook D (2000) Mixed-stock analysis of Atlantic cod near the Gulf of ST Lawrence based on microsatellite DNA. Ecological Applications, 10:1090-1109.

Seminoff JA, Crouse D, Abreu-Grobois FA (2002) 2002 Red List Status Assessment Green Turtle (Chelonia mydas) Marine Turtle Specialist Group.

Seminoff JA (2004) 2004 Global Status Assessment Green Turtle (Chelonia mydas). Marine Turtle Specialist Group. The World Comission Union IUCN. www.iucn.org.

Velez-Zuazo X, Ramos WD, Van Dam RP, Diez CE, Abreu-Grobois A, McMillan O (2008) Dispersal, recruitment and migratory behaviour in a hawksbill sea turtle aggregation. Molecular Ecology 17:839-853.

Waples RS (1990) Separating the weat from the chaff: patterns of genetic differentiation in high gene flow species. The American Genetic Association, 89:438-450.

Zaykin, DV,Pudovkin AI (1993). Two programs to estimate significance of chi-square values using pseudo-probability tests. Journal of Heredity 84: 152.

\section{Capitulo IV}


Balou JD, Foose TJ (1996) Demographic and Management of Captive Populations. In: Wild Animals in captivity: Principles and Techniques. University of Chicago Press, Chicago, 263-283.

Bekessy SA, Allnutt TR, Premoli AC, Lara A, Ennos RA, Burgman MA, Cortes M, Newton AC (2002) Genetic variation in the vulnerable and endemic Monkey Puzzle tree, detected using RAPDs. Heredity, 88:243-249.

Bondioli ACV, Nagaoka SM, Loreto BO, Bahia NCF (2007) Registros de Ocorrência de fibropapilomatose e estudos de caso de juvenis de Chelonia mydas na região de Cananéia, sudeste do Brasil. In: III Jornadas de Conservación e Investigación de Tortugas Marinas en el Atlántico Sur Occidental, Piriápolis,p. 46-47.

Bondioli ACV, Nagaoka SM, Monteiro-Filho ELA (2008) Chelonia mydas. Habitat and occurrence. Herpetological Review, 39:213-213

Brown DM, Brenneman RA, Koepfli K-P, Pollinger, JP, Milá B, Georgiadis NJ, Louis EE, Grether GF, Jacobs DK,Wayne RK (2007) Extensive population genetic structure in the giraffe. BMC Biology, 5:1-13.

Calippo FR (2004) Os sambaquis submersos de Cananéia: um estudo de caso de arqueologia subaquatica. Dissertação de Mestrado. Universidade de São Paulo, São Paulo, 151pp.

Campolim MB, Parada IS, Yamaoka JG(2008) Gestão Participativa da visitação pública na comunidade do Marujá - Parque Estadual da Ilha do Cardoso. Instituto Florestal, 33:39-49.

Cavallari MM (2004) Estrutura genética de populações de Encholirium (Bromeliaceae) e implicações para sua conservação. Dissertação de Mestrado, Universidade de São Paulo, São Paulo, 106pp.

Caraccio MN (2008) Análisis de la composición genética de Chelonia mydas (tortuga verde) en el área de alimentación y desarrollo de Uruguay. Tesis de Maestria. Universidad de la Republica del Uruguay, Montevideo, UY. 89p.

Diegues AC, Arruda RSV (2001) Saberes tradicionais e biodiversidade no Brasil. Brasília, DF: Ministério do Meio Ambiente, São Paulo, USP, 176p.

Dizon ACS, Baker F, Cipriano F, Lento G, Pasboll P, Reeves R (2000) Molecular genetic identification of whales, dolphins and porpoises: proceedings of a workshop on the foensic use of molecular techniques to identify wildlife 
products in the market place. Tech. Memo. NOAA-TM-NMFS-SWFSC-286. NOAA, La Jolla, California.

Frankham R, Ballou JD, Briscoe DA (2002) Introduction to conservation genetics. Cambridge UK, Cambridge University Press, 617p.

Frakham R, Ballou JD, Briscoe DA (2004) A primer to conservation genetics. Cambridge UK, Cambridge University Press, 220p.

Hardwood J (2000) Risk assessment and decision analysis in conservation. Biological Conservation, 95:219-226.

Hogbin PM, Peakall R, Sydes MA (2000) Achieving practical outcomes from genetic studies of rare Australian plants. Australian Journal of Botany, 48:375-382.

IBAMA (2009) Disponível em: <http://www.ibama.gov.br/apacip> Acesso em: 10 de maio de 2009.

IUCN (1984) Threatened protected areas of the world. IUCN Commission on National Parks and Protected Areas, Gland, Suíça.

Maguirre LA, Seal US, Brussard PF (1987) Managing critically endangered species: a case study of the sumatran rhino. In: Viable Populations of Conservation. Cambridge University Press, Cambridge, UK, 141-158.

Moritz C (1994) Defining evolutionary significative units for conservation. Trends in Ecology and Evolution, 9:373:375.

Regan HM, Ben-Haim Y, Langford B, Wilson WG, Lundberg P, Andelman SJ, Burgman MA (2005) Robust decision-making under severe uncertainty for conservation management. Ecological Applications, 15:1471:1477.

UNESCO. 2009. United Nations Educational, Scientific and Cultural Organization. Disponível em: <http://www.unesco.org> . Acesso em 10 de maio de 2009.

Ward RD (2000) Genetic n fisheries management. Hydrobiologia, 420:191-200. 